University of Arkansas, Fayetteville

ScholarWorks@UARK

Graduate Theses and Dissertations

8-2014

\title{
Financial Crisis and the Supply of Corporate Credit
}

Jorge Santiago Emmanuel Barraza

University of Arkansas, Fayetteville

Follow this and additional works at: https://scholarworks.uark.edu/etd

Part of the Finance Commons

\section{Citation}

Barraza, J. (2014). Financial Crisis and the Supply of Corporate Credit. Graduate Theses and Dissertations Retrieved from https://scholarworks.uark.edu/etd/2219

This Dissertation is brought to you for free and open access by ScholarWorks@UARK. It has been accepted for inclusion in Graduate Theses and Dissertations by an authorized administrator of ScholarWorks@UARK. For more information, please contact scholar@uark.edu. 
Financial Crisis and the Supply of Corporate Credit 
Financial Crisis and the Supply of Corporate Credit

A dissertation submitted in partial fulfillment

of the requirements for the degree of

Doctor of Philosophy in Business Administration

by

Jorge Santiago Emmanuel Barraza

Universidad Nacional del Centro de la Provincia de Buenos Aires

Licenciatura en Administración, 2002

Universidad Nacional del Centro de la Provincia de Buenos Aires

Master en Administración de Negocios, 2005

Università degli Studi di Roma Tor Vergata

Master in Economia Europea e Finanza Internazionale, 2006

August 2014

University of Arkansas

This dissertation is approved for recommendation to the Graduate Council.

Dr. Wayne Y. Lee

Dissertation Director

Dr. Alexey Malakhov

Committee Member
Dr. Timothy J. Yeager

Dissertation Director 


\begin{abstract}
This dissertation consists of three essays that study the relationship between distress and credit and the role this relationship has in determining corporate investment and economic activity. The first essay studies the supply of credit during the recent financial crisis. It shows that distress in the banking sector led to bank credit rationing, which a portion of nonfinancial borrowers palliated by migrating to the public market for credit. The overall reduction in credit, however, was followed by a severe drop in corporate investment, which in time led to a fall in the levels of aggregate production.
\end{abstract}

The second essay examines how distress in the banking sector affects credit supply in two separate events: the credit crunch of early 1990s and the financial crisis of late 2000s. While the former is broadly thought of as a relatively mild crisis when compared with the latter, the fall in bank credit that they carried is comparable by certain measures. Government intervention, the paper argues, accounts for the comparatively short duration of and fast recovery from the second crisis.

The third essay investigates the role of aggregate economic distress on the maturity of debt, which ultimately affects investment in long-term assets. The paper predicts and shows that increases in the aggregate distress lead lenders to prefer shorter maturities. This effect can be empirically observed in changes in maturity of new debt issues. Moreover, it is strong enough to modify the temporary financial structure of nonfinancial corporations. 
(C) 2014 by Jorge Santiago Emmanuel Barraza All Rights Reserved 


\section{ACKNOWLEDGEMENTS}

My greatest thanks are due to Dr. Wayne Lee and Dr. Tim Yeager for their unyielding commitment to my success in this program, their generosity, humanity, and invaluable guidance. Special thanks are due to Dr. Pu Liu and Dr. Alexey Malakhov for continuous support, and to the rest of the Finance Department at the Walton College for the challenging yet amicable academic environment they have offered, where we have shared ideas, discussed them, and learnt together.

My studies at the U. of A. have been possible thanks to the Fulbright Program, which brought me to the U.S., and all the generous people who make it possible both in the U.S. and in Argentina. Many thanks to them and to the Sponsored Students Program, the office of International

Students and Scholars, and the Graduate School of Business at the U. of A. for their sponsoring and support. 


\section{DEDICATION}

To my wife, my mom, and my sisters. 


\section{TABLE OF CONTENTS}

I. Introduction 1

II. Essay 1: Financial Crisis and the Supply of Corporate Credit 3

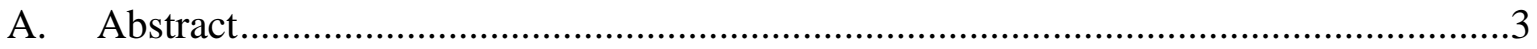

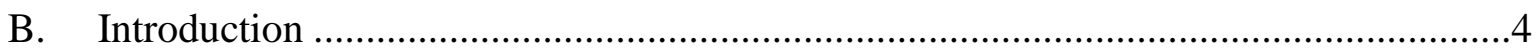

C. Credit Migration in a Financial Crisis ..................................................................10

$\begin{array}{ll}\text { 1. Credit Migration } & 10\end{array}$

$\begin{array}{ll}2 . & 13\end{array}$

$\begin{array}{lll}3 . & \text { Summary Statistics } & 15\end{array}$

4. Dynamics of Debt Funding 16

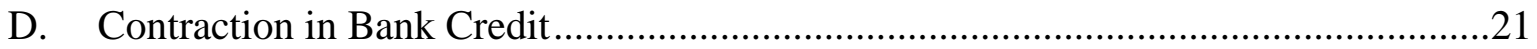

1. Firm Attributes and Debt Funding Choice 22

2. Demand and Supply Influences on Debt Funding Outcomes 22

3. Bank Distress, Liquidity Growth, and Credit Supply 26

4. Lead Arranger Condition and Borrower Migration 28

E. Effect of Loan Contraction on Corporate Investment ……………...............................37

F. Supply Curve Shift or Credit Rationing? ..................................................................

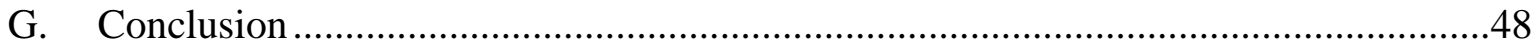

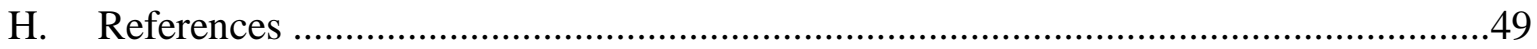

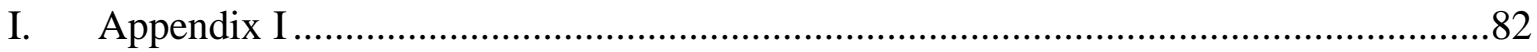

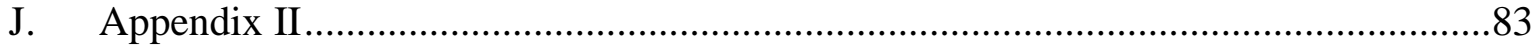

III. Essay 2: Banking Crises: Government Intervention and the Recovery of the Bank

$\begin{array}{lr}\text { Credit Market } & 84\end{array}$

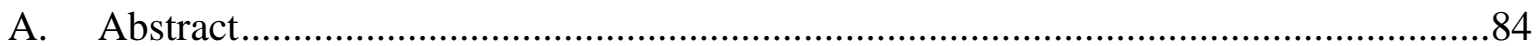




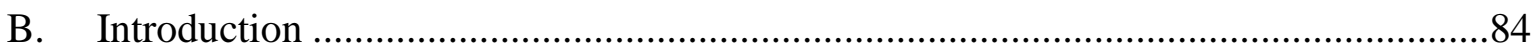

1. The Early 1990s Banking Crisis 85

2. The Late 2000s Banking Crisis 86

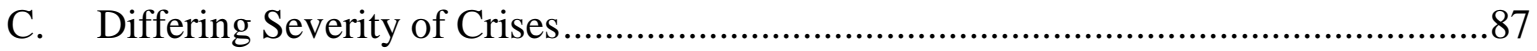

1. Differing Severity of Crises: Banking System Conditions 87

2. Differing Severity of Crises: Fall in Bank Loans and Economic Growth 88

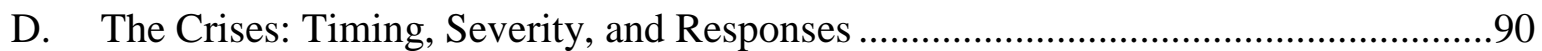

E. Demand vs. Supply: Evidence from Borrowing Migrations ........................................94

1. Steady States and Conditional Probabilities of Borrowing Outcomes 94

2. Market Dynamics: Borrowing Migrations 97

F. Financial Disintermediation as a Result of Banking Crises ........................................98

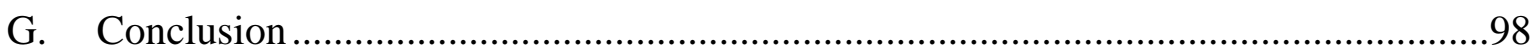

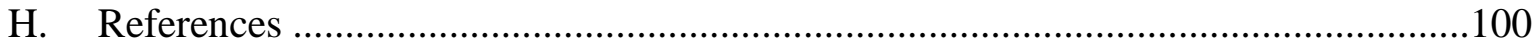

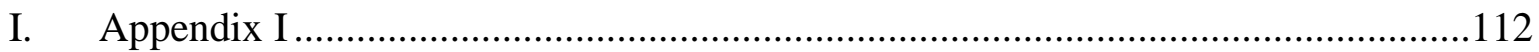

IV. Essay 3: Economic Distress and the Maturity of Debt 113

A. Abstract.....................................................................................................113

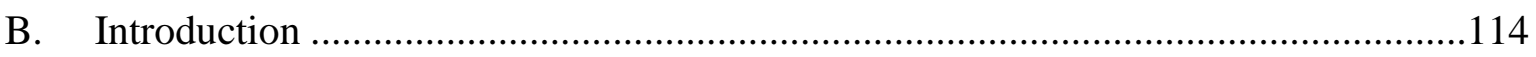

C. The Long-Run Lending Profitability Is a Function of the Borrowers' Probability of Survival, which is a Function of the Contract Tenor ........................................................117

1. Lender's Profit Maximization Problem 118

$\begin{array}{ll}2 . & \text { Comparative Statics } \\ & 120\end{array}$

3. Illustration: Aggregate Economic Risk and Optimal Contracts 122

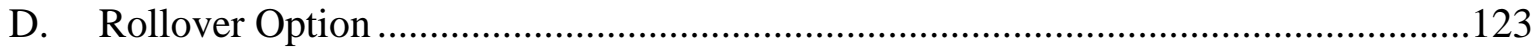


$\begin{array}{ll}\text { 1. Intuition } & 123\end{array}$

$\begin{array}{lll}2 . & \text { Isoprices } & 124\end{array}$

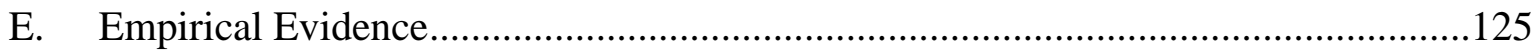

1. $\quad$ Evidence from New Debt Issuances 126

2. Evidence from the Existing Debt on the Balance-Sheet of Nonfinancial Public

$\begin{array}{ll}\text { Corporations } & 129\end{array}$

F. Discussion and Future Developments .........................................................131

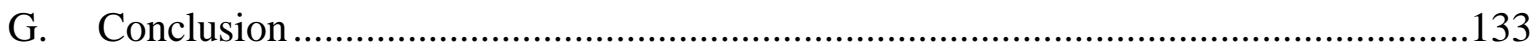

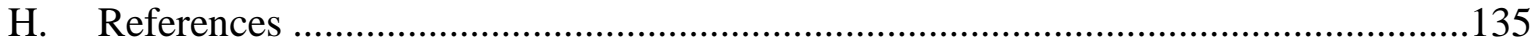

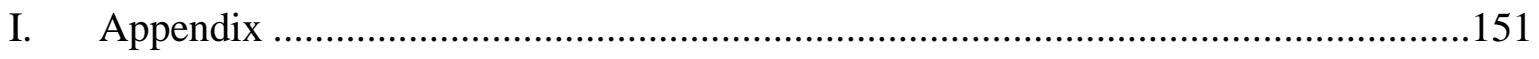

$\begin{array}{lll}\text { V. Conclusion } & 154\end{array}$ 


\section{INTRODUCTION}

This dissertation consists of three essays that relate distress and credit. The first essay studies the supply of corporate credit during the recent financial crisis. In an aggregate of market of bank and public corporate credit, I show that banks ration credit as a response to their distress and in the search to grow liquidity. A fraction of firms react substituting public for bank credit; another fraction is rationed out entirely. This substitution is incomplete because investors are not fully prepared to resolve the information asymmetry problems banks can resolve. A direct result of bank credit contraction is the fall in corporate investment, effect that is particularly strong among firms that borrow from distressed banks.

The second essay is motivated by the far-reaching effects of credit disruptions documented in the first essay. In this second work I explore the impact of government interventions on the duration and severity of credit crises, as well as the pace of recovery from these crises. I compare the credit crunch of early 1990s with the financial crisis of late 2000s. I show that while the former is often considered a mild crisis, it brought a long-lasting contraction in the bank credit market with a total fall in corporate loans that is comparable to that of the latter. The credit crunch, however, had its focus on small- and mid-size banks, while the financial crisis was particularly severe among large banks, which had significant off-balance sheet exposures. The systemic importance of the banks affected in the financial crisis provided incentives for sizeable government intervention, which shortened the duration of the crisis and contributed to a relatively swift recovery in the bank credit market.

The third essay explores the role of aggregate economic distress in determining the maturity of credit. I argue that periods of higher volatility increase the probability of borrower failure, and this makes creditors prefer shorter maturities as an optimal strategy that allows them 
to reduce credit risk exposure and increase the opportunities of screening. Using over twenty years of data, I show that the maturity of new bank and public debt issues decreases when aggregate riskiness increases, and vice versa. Moreover, the effect is strong enough to result in significant changes in maturity of debt outstanding in the balance-sheet of nonfinancial public corporations.

The three essays are subtly intertwined. The common thread to the stories they tell is distress and its impact on credit outcomes and corporate investment. The focus switches at times from financial intermediaries to arms-length investors to nonfinancial corporations, keeping always at sight the implications of aggregate economic distress on the evolution of the real economy. 


\title{
II. ESSAY 1: FINANCIAL CRISIS AND THE SUPPLY OF CORPORATE CREDIT ${ }^{1}$
}

\author{
J. Santiago E. Barraza, Wayne Y. Lee, and Timothy J. Yeager
}

\section{A. ABSTRACT}

Analyzing syndicated loan and public debt originations by publicly traded U.S. firms between 2004 and 2011, we document a sharp migration from bank borrowing to either no borrowing or public debt issuance in the crisis years. A significant portion of the migration was driven by overall distress in the banking industry and a subsequent tightening of lending standards. To conserve liquidity, banks that were relatively more distressed curtailed credit further. Matching each firm with its lead bank, we provide direct evidence for the bank lending channel by showing the migration in debt funding outcomes was more prominent for firms that had established relationships with lead banks that became relatively more distressed during the crisis. The ability of many publicly traded firms to promptly disintermediate and issue their own debt provided important financial flexibility. The damage to the broader economy from the bank lending channel was large, nevertheless, potentially accounting for nearly two-thirds of the decline in

${ }^{1}$ We are grateful for financial support from the Bank of America Research Fund, and to the Arkansas Bankers Association Chair funds, which sponsored access to Thompson Reuters DealScan and Global New Issues databases. We also thank seminar participants at the University of Arkansas, the 2012 FMA Annual Meeting, INFINITI Conference 2013, and the 2013 FMA European Conference for helpful comments. We thank especially Allen Berger, Bruce Dixon, John Duca, Elyas Elyasiani, Alexey Malakhov, Ralf Meisenzahl, Felipe Restrepo Gomez, John Sedunov, Gregory Udell, and Kangzhen Xie for their comments. All errors remain our own. 
nonresidential fixed investment and half of the decline in GDP in 2009. Sticky interest rates and a surge in loan commitment drawdowns suggest that bank credit rationing was prevalent during the crisis. Many firms originated public debt at interest rates far higher than syndicated loan rates.

Keywords: financial crisis, bank lending channel, credit rationing, financial flexibility. JEL Codes: G12, G21, G32.

\section{B. INTRODUCTION}

The most important role of financial institutions is to channel funds from savers to borrowers, which facilitates aggregate consumption and investment. Historically, commercial banks have been the primary intermediaries. When bank lending is interrupted, the consequences can be grave. Bernanke (1983) makes a convincing case that the U.S. economy slipped from a typical recession into the Great Depression only when banks failed in large numbers, which disrupted lending relationships and caused a large contraction in aggregate demand. In a centurieslong study of financial crises, Reinhart and Rogoff (2009) find that banking crises were followed by particularly long and extreme contractions in economic activity.

Conventional wisdom that a sharp contraction in credit provided by U.S. banks during the 2008-2009 financial crisis contributed to a severe and prolonged recession has conceptual merit. Federal Reserve data show that bank lending dropped by $10.2 \%$ in 2009 and 5.8\% in 2010. Absent drawdowns on existing loan commitments, the decline in bank lending would have been significantly worse. ${ }^{2}$ Large banks were accused of accumulating cash and curtailing lending

\footnotetext{
${ }^{2}$ Loan data are from the Federal Reserve Board of Governors Table H.8, "Assets and Liabilities of Commercial Banks in the United States." Total unused commitments at commercial banks declined by one fourth from $\$ 7.2$ trillion at year-end 2007 to $\$ 5.4$ trillion at year-end 2009 . Federal
} 
despite billion dollar infusions of capital through the Troubled Asset Relief Program (TARP). ${ }^{3}$ But U.S. financial markets are much deeper and wider than in the 1930s and firms have far more financial flexibility. Even if banks rationed credit subsequent to the bursting of the housing bubble, nonbank intermediaries could potentially take up the slack and offset the decline in bank lending. Further, a decrease in demand for bank loans could account for some or all of the decrease in bank lending either because firms tapped internal funds or voluntarily reduced investment.

Using firm-level contract data on syndicated loans and public debt issues, this study examines the importance of the U.S. bank lending channel to corporate financing and investment during the financial crisis. We find that the contraction in bank lending played a distinctly important role in the aggregate allocation of credit in 2008 , which led to an economically large reduction in the investment of firms in 2009 and thereby contributed to the Great Recession.

Following the subprime housing bubble burst in 2007, banks responded to the heightened threat of insolvency by reducing loan growth and increasing liquidity in 2008 and 2009. The credit contraction led to a sharp increase in the number of firms that did not borrow at all or migrated to the public debt markets. Steady-state dynamics derived from transition matrices of corporate debt funding in crisis-years 2008-2009 and pre-crisis years 2005-2006 suggest the crisis induced a 24 percentage point decline in the number of firms using bank debt, approximately half of whom obtained no credit at all and the remaining half issued public debt. Controlling for the attributes

Deposit Insurance Corporation, Statistics on Depository Institutions.

${ }^{3}$ See, for example, Matthias Rieker, Marshall Eckblad, and Joe Bel Bruno, "Bank Executives to Tell Congress: 'We're Lending,," Wall Street Journal, February 11, 2009; and Steffy, Loren, "You bail me out, I'll bail you out," Houston Chronicle, December 30, 2009. 
of firms that influence debt funding choice as well as the characteristics of bank and public debt contracts, logistic regressions of pre-crisis and crisis debt funding outcomes affirm that firms were far less likely to obtain syndicated bank loans and far more likely to issue public debt during the crisis. Compared to pre-crisis years 2004-2006, the likelihood that firms obtained syndicated bank loans fell by 4\% (9\%) in 2008 (2009); and the likelihood that firms obtained public debt rose by 19\% (27\%) in 2008 (2009). The differences in debt funding outcomes at the firm level were coincident with a tightening of commercial and industrial (C\&I) lending standards by commercial banks.

The primary empirical challenge in bank lending channel studies is to distinguish between demand and supply shifts. We address this issue by identifying the lead arranger of each firm and noting the ensuing debt funding outcomes of each firm as the relative financial distress of the lead arranger changes. We conjecture that banks, which became relatively more distressed during the crisis contracted lending the most (Gambacorta and Marques-Ibanez 2011), and as a consequence, made it more difficult for firms with relationships to these banks to obtain credit. Indeed, multinomial regressions show that firms who borrowed in 2007 from bank lenders that subsequently became more distressed in 2008 were less likely to borrow in 2008 .

Firms that either did not borrow or had relationships with distressed lenders in 2008 were also less likely to invest in 2009 , and the effect was economically large. In multivariate regressions, which account for factors that can influence a firm's demand for investment, we estimate the contraction in bank lending reduced firm investment in 2009 by $24 \%$. The reduction in firm investment accounts for approximately two-thirds of the decline in nonresidential fixed investment, and translates into a decrease in Gross Domestic Product (GDP) of 1.5\%, more than half of the GDP contraction of $2.8 \%$ in 2009 . 
Evidence from loan commitment drawdowns and sticky loan rates suggest that banks chose to ration credit rather than raise interest rates. C\&I drawdowns under commitments a year and older as a proportion of total C\&I loans increased unexpectedly in late 2008. Firms drew heavily on existing lines and were unable to obtain new lines under comparable borrowing terms. At the same time, average interest rate spreads on bank loans, which were not statistically different from bond spreads in non-crisis years, were 137 (67) basis points lower than on bond debt in the crisis year 2008 (2009); differences that are both economically and statistically significant. All things equal, given the significantly lower cost of bank debt during the crisis, firms would have preferred to borrow from banks. We suppose the rapid deterioration in bank capital from a substantial decline in subprime asset values did not allow banks the opportunity to raise additional capital at reasonable cost nor provide the time needed to reduce credit volume through higher interest rates.

To the best of our knowledge, no other paper has quantified the real effects of bank distress and the consequent contraction in bank lending during the financial crisis on the U.S. economy, accounting simultaneously for a number of demand and supply factors. Our analysis shows a large contraction in investment, even though many firms were able to draw down cash and migrate to public debt markets in response to the reduction in bank credit. Our results roughly coincide with Kahle and Stulz (2013) findings regarding the timing of this impact on firm investment. Although the financial crisis started in late 2007 and peaked in 2008, the strongest effect of the bank credit channel on firm investment only occurred in 2009.

Our study corroborates the importance of the bank lending channel during periods of financial crisis (Bernanke 1983) and the relatively limited substitutability of credit sources. The destruction of credit relationships that result when banks fail takes time to rebuild. The resulting reduction in aggregate demand can be acute even in an otherwise robust economic environment 
(Ashcraft, 2005). Using the Russian crisis in the fall of 1998 as an adverse shock to the health of some U.S. banks, Chava and Purnanandam (2011) note that borrowers dependent on credit from affected banks experienced significantly higher valuation losses. Gan (2007) examines the bursting of the real estate bubble in Japan. The reduction in credit by banks with greater real estate exposure accounted for one-third of the contraction in lending and one-fifth of the decline in investment. Jiminez, Ongena, Peydro, and Saurina (2012) find that contractionary monetary policy in Spain during the 2000s led to more severe credit contraction by banks with lower capital and liquidity. Neither of these countries, however, had public bond markets as deep as in the U.S., which makes the debt migration dynamics in our study unique. Lastly, Lemon and Roberts (2010) observe that after 1989, some firms managed to switch to bank loans and other financing sources when the high-yield public debt market was adversely affected by a number of shocks. However, given the limited substitutability of the sources of funding, corporate investment deteriorated considerably over the same period.

Our results also advance the literature on bank demand for liquidity by showing that a crisis-induced increase in insolvency risk encourages liquidity hoarding and credit contraction. Cornett, McNutt, Strahan, and Tehranian (2011) report that banks that entered the crisis with high liquidity risk - that is, exposure to undrawn loan commitments and wholesale funding withdrawals, added liquidity and extended less credit than banks with less liquidity risk. Acharya and Skeie (2011) argue that a bank's willingness to lend in the short-term inter-bank market is determined by its own rollover risk. The aversion to rollover risk should be more pronounced with longerterm lending. Finally, Caballero and Krishnamurthy (2008) point out that financial intermediaries become self-protective and amass liquidity when the aggregate quantity of liquidity is limited and agents face Knightian uncertainty with immeasurable risks. 
Lastly, our study concludes that credit rationing occurred during the crisis and was more prevalent when banks were in severe distress. Stiglitz and Weiss (1981) rationalize credit rationing as a possible equilibrium outcome. When lenders have imperfect information about the credit risks of borrowers, interest rate setting may not be an optimal market clearing mechanism. Raising the rate of interest can either attract a riskier pool of potential borrowers (adverse selection effect) or induce firms to increase the riskiness of existing projects (incentive effect). Empirically documenting credit rationing is challenging. Berger and Udell (1992) test two key predictions of this theory. First, rationing requires that the fraction of new loans disbursed under prior existing commitments rises when credit spreads are high because non-commitment borrowers can readily be rationed but commitment borrowers cannot. Using data from the Federal Reserve Board of Governors Survey of Terms of Business Lending, we show that the quarterly ratio of C\&I loans originated under commitment to all C\&I loans rose steadily between 2007 and 2010, coinciding with a period of extremely high interest rates for corporate credit. Second, sticky interest rates provide evidence of credit rationing absent alternative explanations such as implicit interest rate insurance or re-contracting with troubled borrowers. We can directly rule out the first alternative because interest rate insurance is achieved through disbursements from existing loan contracts; the syndicated loans in our dataset are new originations. We rule out re-contracting with troubled borrowers because very few of the sample firms have ratings at the lowest end of the scale, such as $\mathrm{CC}$ or D.

The remainder of the paper is organized as follows. Section II makes a case for a fall in the proportion of loan to bond originations in a financial crisis that threatens bank solvency. Section III documents the migration from loans to bonds, especially in 2008 and 2009, and shows that debt migration was at least partly driven by shifts in the supply of bank credit. Section IV 
examines corporate debt funding outcomes during the financial crisis and the impact of bank distress. Section V evaluates the effect of a contraction in bank lending on corporate investment. Section VI documents that banks rationed credit. Firms migrated to bond markets even though lending banks provided credit at lower interest rates. Section VII concludes.

\section{CREDIT MIGRATION IN A FINANCIAL CRISIS}

In this section, we provide a conceptual rationale for, and empirically document the migration of credit from syndicated bank loans either to public debt or no debt during the financial crisis. Although credit migration applies to all corporate loan and bond issues, reliable firm-level origination data are available only on syndicated loans and public bond issues. The scope of our empirical study is limited accordingly.

\section{Credit Migration}

Severe distress at the largest banks can trigger credit migration. Rollover risk, loan commitment drawdowns, and speculative cash motives affect the liquidity preferences of banks. A solvency crisis increases the chance that banks will not be able to roll over their liabilities (Acharya and Skeie, 2011; Ashcraft, McAndrews, and Skeie, 2011). Although insured deposits are unlikely to flee, on average only about $39 \%$ of the liabilities of large bank are FDIC insured. ${ }^{4}$ In contrast, uninsured funding can depart overnight. Moreover, even the use of collateralized debt is uncertain when asset values underlying the collateral deteriorate. As Gorton and Metrick (2012) show, REPO markets ceased to function as the value of subprime mortgages collapsed. Furthermore, in a crisis, banks also confront an increased demand for liquidity by firms. Loan

\footnotetext{
${ }^{4}$ FDIC Statistics on Depository Institutions, March 2013.
} 
commitments are drawn down more aggressively when firms anticipate an increased need for cash either because they may not be able to obtain new loans quickly or because the crisis has a direct impact on their own cash flows (Ivashina and Scharfstein, 2010). Lastly, Acharya, Shin, and Yorulmazer (2011) find that fire sales of failed banks during crises induce healthy banks to hold higher levels of liquidity in order to profit from acquisition opportunities.

Curbing loan originations is a rational reaction by banks to conserve liquidity. This action, which slows or reverses asset growth, also assists banks in satisfying regulatory capital requirements. The decline in originations can be implemented either through a rise in interest rates or by rationing the volume of credit. We hypothesize that in the short run, banks ration credit when the need to retain liquidity outweighs the marginal foregone interest revenue from raising interest rates. The adverse selection rationale for credit rationing (Stiglitz and Weiss, 1981) where higher interest rates increase the riskiness of the pool of borrowers is consistent with our story.

The effect of a contraction in loan supply on firms depends on their reliance on bank loans for debt financing. On the one hand, opaque firms and smaller privately held firms - namely, firms that equity and bond markets know little about, must rely on bank expertise in resolving information asymmetry through screening and monitoring. On the other hand, publicly traded firms are relatively more transparent, which lessens the need for bank intermediation, because investors confront lower uncertainty about project outcomes (Besanko and Kanatas, 1993). Moreover, sufficiently large firms can rely on reputation or certification by third party credit rating agencies to aid investors in assessing credit risks. Cantillo and Wright (2000) find that firms that finance through the public debt market are generally larger, safer, more profitable, and have relatively more cash and collateral. These findings are broadly consistent with Houston and James (1996); Johnson (1997); Krishnaswami, Spindt, and Subramaniam (1999); and Denis and Mihov 
(2003).

In a financial crisis, as distressed banks curtail lending, firms with access to public debt markets are much more likely to substitute public for bank debt. ${ }^{5}$ The total volume of debt origination may not increase relative to the pre-crisis period, however, both because debt substitution is imperfect and because a slowing economy reduces firms' demand for credit. Bankdependent borrowers are more likely to be priced or rationed out of the credit market altogether. The proportion of bank loan to bond originations should fall in a financial crisis. Indeed, Becker and Ivashina (2014) observe that declines in the proportion of bank loans to bond originations ensue at times characterized by tight lending standards.

\section{[Insert Figure 1 here.]}

Our crisis migration story is illustrated succinctly in Figure 1. The initial equilibriums in the bank and public debt markets occur at $\mathrm{E}_{\mathrm{B}, \mathrm{O}}$ and $\mathrm{E}_{\mathrm{P}, \mathrm{O}}$, respectively, at which credit funds are competitively priced in both markets. ${ }^{6}$ The uncertainty triggered by the crisis decreases the

\footnotetext{
${ }^{5}$ Equity issuances by firms is possible. However, stock prices tend to be depressed during a crisis because future cash flows are more uncertain, which exacerbates the asymmetric information problem between firms and investors.
}

${ }^{6}$ Our univariate analysis in Table 1 provides some evidence that bank debt can be slightly more expensive than public debt during normal times. This could reflect the additional monitoring costs banks incur, as well as the ability of banks to extract monopolistic rents, consistent with Diamond (1984); Sharpe (1990); Rajan (1992). Our multivariate analysis in Table 10 does not show, however, that these pricing differences are statistically significant after controlling for contract and 
willingness of all lenders to extend credit, as they perceive higher credit, liquidity, and solvency risks. The supply curve for bond debt provided by institutional and retail investors shifts left from $\mathrm{S}_{\mathrm{P}, 0}$ to $\mathrm{S}_{\mathrm{P}, 1}$. Banks simultaneously curtail lending even to well-qualified borrowers, shifting the supply curve left from $S_{\mathrm{B}, 0}$ to $\mathrm{S}_{\mathrm{B}, 1}$. Distressed banks account for most of the contraction in bank credit. In addition, credit rationing by banks cause a backward bend in the supply curve as banks become unwilling to lend even at higher interest rates. Reflecting a weaker economy, the demand curve for bank debt also shifts left from $\mathrm{D}_{\mathrm{B}, 0}$ to $\mathrm{D}_{\mathrm{B}, 1}$. The price of bank debt does not clear the bank debt market because the credit volume supplied at $\mathrm{C}_{\mathrm{B}, 1}$ is less than the credit volume demanded at a higher interest rate, $\mathrm{r}_{\mathrm{B}, 1 .}{ }^{7}$ With the contraction in loan supply, otherwise wellqualified borrowers migrate to the public debt market, shifting the demand curve rightward from $\mathrm{D}_{\mathrm{P}, 0}$ to $\mathrm{D}_{\mathrm{P}, 1}$. The public debt market clears at a higher loan volume, $\mathrm{C}_{\mathrm{P}, 1}>\mathrm{C}_{\mathrm{P}, 0}$, but at a higher rate of interest than on bank debt, $\mathrm{r}_{\mathrm{P}, 1}>\mathrm{r}_{\mathrm{B}, 1}$. Because the migration from bank credit to bond credit is incomplete and aggregate demand for credit declines, the total volume of credit in the economy falls such that $\mathrm{C}_{\mathrm{B}, 1}+\mathrm{C}_{\mathrm{P}, 1}<\mathrm{C}_{\mathrm{B}, 0}+\mathrm{C}_{\mathrm{P}, 0}$. Crisis outcomes in the markets for bank and public debt are denoted by $\mathrm{E}_{\mathrm{B}, 1}$ and $\mathrm{E}_{\mathrm{P}, 1}$ respectively.

\section{Data Sample}

In recent years, syndicated loans have replaced traditional commercial and industrial bank

firm characteristics.

${ }^{7}$ We could call this a Walrasian partial disequilibrium. But authors Stigliz and Weiss (1981) and Keeton (1979) argue that a non-clearing price can also be compatible with a market equilibrium in credit markets. 
loans in importance because syndication allows banks to diversify their loan portfolios, achieve transactional economies of scale, and secure liquidity in the secondary market for syndicated loans. In a syndicated loan transaction, a lead bank (or banks) plays the central role of screening the borrower, negotiating the deal structure ex ante, and monitoring the loan ex post (Ivashina, 2009). The loan is marketed to a diverse group of banks and investors and the level of investor interest in the deal determines the eventual yield spread over a benchmark rate. Because firms that borrow in the syndicated loan market are relatively larger in size and more transparent to investors, many of these firms also have the ability to borrow in public debt markets.

We examine originations of syndicated bank loans and non-convertible public debt by publicly traded non-financial firms between January 2004 and December $2011 .{ }^{8}$ We define 20042006 as the pre-crisis years, 2008-2009, as the crisis years, and 2010-2011 as the post-crisis years; based on the annual aggregate data, 2007 can be considered a transition year. Data on syndicated loan originations were obtained from Thomson Reuters DealScan, and data on public debt originations come from Thomson Reuters Securities Data Commission ( $S D C$ ) Platinum. We point out that the syndicated loans dataset includes loans marketed through distribution methods other than syndication. Although syndication accounts for almost $90 \%$ of the sample, the sample also includes $0.11 \%$ in bilateral loans, $0.21 \%$ in club deal loans, and $10.54 \%$ in sole lender loans. We include these loans in our data sample because our study focuses on the importance of bank lending and lender-client relationships rather than the specific distribution method employed to market the credit.

We use LIBOR data from the Bloomberg S23 US Dollars Swaps curve to compute yields

\footnotetext{
${ }^{8}$ We exclude financial firms in Standard Industrial Classification codes 6000 through 6999.
} 
on loans that use LIBOR as a base rate. Similarly, we employ Treasury constant maturity rates obtained from the Federal Reserve Bank of St. Louis website to compute loan and bond spreads over the risk-free rates.

\section{Summary Statistics}

Table 1 presents summary statistics on the number, volume, and characteristics of loan originations and bond issues by year. The number of loans declined by more than half during the crisis years. Volume declined from an average $\$ 930$ billion in pre-crisis years to $\$ 412$ billion in crisis years. In contrast, the volume of public debt issues increased $153 \%$ from an average $\$ 99$ billion in pre-crisis years to $\$ 252$ billion in crisis years. Loans as a share of aggregate credit declined as well. In pre-crisis years, loans accounted for $90 \%$ of the aggregate number of contracts and credit volume; during the crisis these shares averaged $70 \%$ and $62 \%$, respectively, before partially recovering in 2010 and 2011. Moreover, even though average firm size was large, nearly $90 \%$ of firms borrowed only from banks in the pre-crisis years, and the share declined to $78 \%$ in 2008 and $65 \%$ in 2009. At the same time, the number of firms that only issued bonds increased from an average $4 \%$ in the pre-crisis years to $15 \%$ in 2008 and $25 \%$ in 2009 . Clearly the bond market was a more important source of credit in the crisis years compared to the pre-crisis years, both in absolute and relative terms.

\section{[Insert Table 1 here.]}

In general, banks specialize in financing short-term and medium-term debt, and public debt markets specialize in long-term debt. Consistent with a higher preference for liquidity and lower tolerance for credit risk by debt providers, the maturities on loans and public debt shortened in the crisis years. In the pre-crisis years, the average maturity on loan contracts was 55 months 
compared to an average 159 months on bond contracts. By 2009, the average maturity on loans fell by $33 \%$ to 37 months, and the average maturity on bonds fell by $19 \%$ to 129 months.

Public debt markets cater predominantly to creditworthy investment-grade firms (BBB and above); banks, in contrast, extend credit across the entire credit risk spectrum. During the crisis, the relative share of loan originations declined across every ratings category B and above, and the decline was particularly severe for investment grade firms, which were more likely to migrate to the bond market. In pre-crisis years, banks originated the majority of debt contracts across all credit ratings, including firms rated AA- and above. But in 2009, banks originated only $35 \%$ of debt contracts to firms rated AA- and above and just $30 \%$ of debt contracts to firms rated BBB. Even non-investment-grade firms relied relatively more heavily on public debt markets during the crisis. The public debt share of BB firms reached 30\% in 2009 from a high of 9\% pre-crisis.

The pattern of yield spreads in Table 1 are consistent with banks choosing to ration credit rather than raise interest rates to clear the bank credit market during the crisis. Pre-crisis, yield spreads on loan and bond originations were not statistically different. But in 2008, yield spreads on investment and non-investment grade loans were well below corresponding yield spreads on bond issues. In 2009, yield spreads on the high end of investment-grade loan and bond issues converged. However, yield spreads on the low end of investment-grade and, specially, on noninvestment-grade loans remained substantially lower than yield spreads on bonds. Banks appeared to continue rationing speculative credit rated firms. Post crisis, yield spreads on loans rose and were significantly higher than corresponding yield spreads on bonds.

\section{Dynamics of Debt Funding}

The pattern of loan and bond originations in Table 1 reflect a significant switch from bank to public debt during the crisis. To substantiate migration, we compute (Markov) transition 
matrices of corporate debt funding; dividing the years 2004-2011 into seven overlapping two-year periods (2004-2005 through 2010-2011) and tracking the debt choices of each firm at year $t$ and $t+1$ in each rolling two-year window. ${ }^{9}$ We classify firms in the first and second years into one of four possible states; namely, the firm originated: (i) no debt; (ii) loans only; (iii) bonds only; or (iv) both loans and bonds. We define aggregate credit markets each year by the distribution of debt financing summarized in a four-dimensional state vector $\boldsymbol{x}\left[x_{i}\right]$, where $x_{i}: i=1,2,3,4$ represent the percentages of firms that fall into each of the four states.

The changes in the state distribution between the first and second year reflect the dynamics of debt choices by firm. Assuming changes follow a Markov process, a four-by-four dimensional transition matrix, $\boldsymbol{T}\left[t_{i j}\right]$, describes the passage of firms to state $i$ in the second year from state $j$ in the first year. $t_{i j}=c_{i j} / \sum_{i} c_{i j}$ for every column $j$, where $c_{i j}$ is the count of firms that fall into state $i$ in the second year and state $j$ in the first year, respectively, and $\sum_{i} t_{i j}=1$ for every $j$ column. $t_{i j} \geq 0$ represents the conditional probability that a firm migrates to final state $i$ in the second year from initial state $j$ in the first year.

For a regular time-invariant transition matrix $\boldsymbol{T}$, there exists a matrix $\boldsymbol{A}$ such that

\footnotetext{
${ }^{9}$ The pool of firms in each two-year window ( $t$ to $\left.t+1\right)$ are firms that borrowed sometime over the three-year period $t-1$ to $t+1$. This restriction on the pool of borrowing firms, and thereby the implied size of debt markets, allows for the possibility that firms that did not borrow in $t$ also did not borrow in $t+1$. The potential bias introduced by this restriction on transition matrices is relatively minor because only the corner element 1,1 in the transition matrix is impacted. The results presented herein are robust to alternative specifications of the window and implied debt market size.
} 
$\lim _{n \rightarrow \infty} \boldsymbol{T}^{n}=\boldsymbol{A}$. The column vectors $\boldsymbol{u}$ of $\boldsymbol{A}[\boldsymbol{u}]$ are identical and each represents the steady-state distribution of debt financing where $u_{i j} \geq 0$ and $\sum_{i} u_{i j}=1$ for every $j$. Independent of the initial state $\boldsymbol{x}$, it holds that $\lim _{n \rightarrow \infty} \boldsymbol{T}^{n} \boldsymbol{x}=\boldsymbol{A} \boldsymbol{x}=\boldsymbol{u}$.

Consider the firms that borrowed in the two-year period 2004-2005. The state vectors $\boldsymbol{x}_{2004}$ and $\boldsymbol{x}_{2005}$ characterize the distribution of debt financing in 2004 and 2005, and the transition matrix $\boldsymbol{T}_{2004,2005}$ describes the changes in debt choice by firms between 2004 and 2005.

$$
\begin{gathered}
x_{2005}=\boldsymbol{T}_{2004,2005} x_{2004} \\
{\left[\begin{array}{l}
.424 \\
.520 \\
.020 \\
.037
\end{array}\right]=\left[\begin{array}{llll}
.333 & .509 & .333 & .182 \\
.639 & .456 & .133 & .398 \\
.013 & .011 & .333 & .068 \\
.015 & .024 & .200 & .352
\end{array}\right]\left[\begin{array}{l}
.397 \\
.546 \\
.019 \\
.038
\end{array}\right]}
\end{gathered}
$$

The steady state distribution of debt financing over the 2004-2005 period is $\lim _{n \rightarrow \infty} \boldsymbol{T}_{2004,2005}^{n} \boldsymbol{x}=\boldsymbol{A}_{2004,2005} \boldsymbol{x}=\boldsymbol{u}_{2004,2005}$

$$
\boldsymbol{u}_{2004,2005}=\left[\begin{array}{l}
.420 \\
.524 \\
.021 \\
.036
\end{array}\right]
$$

The 2004-2005 debt funding dynamics imply a long-run equilibrium where: $42 \%$ of firms will not borrow; $52.4 \%$ will obtain bank debt; $2.1 \%$ will obtain public debt; and the remaining $3.6 \%$ will obtain both bank and public debt.

The results of the Markov transition analysis are summarized in Table $2 .{ }^{10}$ Panel A reports

\footnotetext{
${ }^{10}$ To ensure firms that disappeared over the sample period do not drive our results, we restrict our Markov chain analysis to include only firms that were in business between $t-1$ and $t+1$ in each
} 
the seven steady state distributions of debt financing derived from two-year rolling windows over the years 2004-2011. The debt funding dynamics in the pre-crisis years - 2004-2005, 2005-2006, 2006-2007, imply that: an average $48.5 \%$ of firms will secure bank loans only; $3.2 \%$ will secure bonds only; and 4.5\% will secure both loans and bonds. Over the entire 2004-2007 pre-crisis period, the proportion of firms that will borrow from banks is 6.9 times the number of firms that will borrow from public bond markets. Roughly $4 / 9$ of firms will not borrow at all in any given year.

[Insert Table 2 here.]

In contrast to pre-crisis years, in the crisis years of 2007-2008 and 2008-2009, debt funding dynamics imply that: just an average $28.5 \%$ of firms will secure bank loans only; $11 \%$ will secure bonds only; and 3.9\% will secure both bank and public debt. For every two firms that will borrow from a bank, one firm will borrow from the public debt market; a sharp divergence from pre-crisis years. More than 5/9 of firms will not borrow at all in the 2007-2008 and 2008-2009 periods. Further, in 2007-2008, 57.8\% of firms will not borrow at all, significantly lower than the 19892011 average; and in 2008-2009, the proportion of firms borrowing bank (public) debt only is significantly lower (higher) than the 1989-2011 average.

The post-crisis years 2009-2010 and 2010-2011 show a clear recovery in credit markets. The proportion of firms that will only borrow from banks is higher than in the crisis years and close in magnitude to the pre-crisis years. The proportion of firms that will only issue bonds are

two-year rolling window. We report results using this specification although the results are robust to the removal of this filter. 
lower than in the crisis years, and again, close to magnitudes in the pre-crisis years. The proportion of firms that will not borrow at all is extremely low; lower than in the pre-crisis years and significantly lower than the 1989-2011 average. Post-crisis, more firms will seek to diversify their sources of debt funding. Almost 10\% will borrow from both bank and public debt markets in 2010-2011 compared to a peak of 5.3\% in the pre-crisis years and a trough of $2.8 \%$ in the crisis years; and the proportion that borrow from both bank and public debt markets in 2010-2011 is significantly higher than the 1989-2011 average.

The conditional probabilities reported in Panel B corroborate our thesis that a contraction in bank lending will trigger a shift from bank to public debt. On the one hand, the probability of securing bank debt conditional on securing public debt in the same year ranges between $25 \%$ and $29 \%$ in the crisis years in contrast to peaks of $64 \%$ in the pre-crisis years $2004-2005$ and $72 \%$ in the post-crisis years 2010-2011. On the other hand, the probability of securing public debt conditional on securing bank debt in the same year is as high as $11 \%$ in the pre-crisis years 20062007, but reaches as high as 17\%, in the crisis years 2008-2009. Firms with access to public debt markets will substitute public for bank debt in the crisis years, and thereby, will be less adversely affected by a contraction in bank lending in crisis years.

The average transition matrices in the pre-crisis, crisis, and post crisis years presented in Panel $\mathrm{C}$ of Table 2 provide further insights on debt funding dynamics. The columns describe the (average) initial debt funding outcome; the rows describe the final debt funding outcome. Consider the second column in the average transition matrix over the pre-crisis years. In pre-crisis years, for firms that initially borrow from banks; in the subsequent period: an average $54.2 \%$ will not borrow at all, $40.3 \%$ will secure bank debt only, $1.9 \%$ will switch from bank to public debt, and 3.6\% will obtain both bank and public debt. But in crisis years, for firms that initially borrow from 
banks; in the subsequent period: an overwhelming average $74.7 \%$ will not borrow at all, just $19.4 \%$ will secure bank debt only, $3.1 \%$ will switch from bank to public debt, and $2.7 \%$ will obtain both bank and public debt.

In pre-crisis years, for firms that initially issue public bonds, in the subsequent period an average $34.4 \%$ will not borrow at all, $23.3 \%$ will switch from public bonds to loans only, $26.7 \%$ will secure public bonds only, and $15.6 \%$ will obtain both bank and public debt. But in crisis years, for firms that initially issue public debt, in the subsequent period an average $41.4 \%$ will not borrow at all, just $7.3 \%$ will switch from public bonds to loans only, a stunning $43 \%$ will secure public bonds only, and $8.3 \%$ will obtain both bank and public debt.

Taken together, debt funding dynamics predict a larger adverse impact on bank-dependent firms from a contraction in bank lending. Firms that initially borrow from banks will subsequently be relatively less likely to borrow from banks, and more likely to issue public debt in crisis years than pre-crisis years. Firms that initially issue public debt will also subsequently be relatively less likely to borrow from banks and more likely to issue public debt in crisis years than pre-crisis years. Firms with clear access to public debt markets will be able to substitute public debt for bank loans. In other words, the percentage of firms that initially borrow from banks and subsequently switch to public debt will be considerably higher in crisis years than pre-crisis years. And the percentage of firms that initially issue public debt and subsequently continue to issue public bonds will also be considerably higher in crisis years than pre-crisis years.

\section{CONTRACTION IN BANK CREDIT}

Taking the credit demand of firms into consideration, we show in this section that a tightening of lending standards by banks lowered the likelihood that firms received bank credit during crisis years. Moreover, the reduction in the supply of bank credit was driven in part by a 
desire of banks to increase liquidity. Lastly, we match firms to their lead arrangers and find that an increase in bank distress during crisis years contributed to the migration of firms from bank to public debt markets.

\section{Firm Attributes and Debt Funding Choice}

Because firms differ in their funding needs, it is important to control for the attributes that influence their choice of debt funding. Table 3 presents summary statistics on borrower firm attributes grouped by debt funding choice are presented in Table $3 .{ }^{11}$

[Insert Table 3 here]

Over the entire sample period 2004 to 2011, firms that obtained debt through syndicated bank loans rather than public debt issues: were less profitable (ROA); held fewer assets and fewer (tangible) fixed assets; held more cash; had weaker credit ratings (ratings are numbered 1 to 22 with higher values representing better ratings); and younger. The Tobin $Q$ of firms that obtained bank credit was also higher than on firms that relied on public debt issues in the pre-crisis period, but the reverse was true in the crisis and post-crisis periods. Overall, higher creditworthy firms participated in the bond market. De Fiore and Uhlig (2012) note similar patterns for non-financial firms in European markets.

\section{Demand and Supply Influences on Debt Funding Outcomes}

Using contract level data, we estimate a prediction model of debt funding choice for the pre-crisis years 2004-2006 to assess how potential shifts in credit demand and supply influence

${ }^{11}$ Firm attributes are from the Compustat database. For public debt, we matched the SDC Platinum database directly with Compustat by Cusip. For syndicated loans, we matched DealScan with Compustat using the linking table from Chava and Roberts (2008). 
the observed change in debt funding outcomes of firms that borrowed during the crisis years. The coefficient estimates from the pre-crisis model are used to establish the normal probability that an observed contract-firm pair in a given year corresponds to a bank loan or a bond issue. The same model specification is also utilized to estimate, for each year between 2004 and 2011, the imputed probability that an observed contract-firm pair corresponds to a bank loan or a bond issue. The excess probability is the difference between the imputed and normal probabilities that an observed contract-firm pair corresponds to a syndicated bank loan or bond issue. We report the average excess probability across contract-firm pairs for each year between 2004 and 2011 .

Our estimates of excess probabilities employ two alternative specifications. The Base Model includes only contract and firm characteristics, which control primarily for the impact of demand factors on contract type. The Full Model includes, additionally, a proxy for bank credit supply conditions. To the extent that firm and contract variables accurately capture the debt funding choices of firms, the differences in excess probabilities computed from the Base and Full Models reflect the effect of supply constraints on debt funding choices by firms.

The general form of the logistic regression, which closely follows Denis and Mihov (2003), is:

$$
\text { Contract Type }_{j, t}=\alpha+\gamma \boldsymbol{C}_{j, t}+\varphi \boldsymbol{F}_{i, t-1}+\psi S_{t}+\varepsilon_{j, t}
$$

Where Contract Type $_{j, t}$ is a binary variable that equals 1 if a credit contract $j$ of borrower $i$ is a bank loan in a given year $t$, and 0 if it corresponds to a bond; $\alpha$ is an intercept; $\boldsymbol{C}_{j, t}$ and $\boldsymbol{F}_{i, t-1}$ are vectors of contract and firm characteristics, respectively; $S_{t}$ is a measure of bank credit supply conditions during $t$; and $\varepsilon_{j, t}$ is the error term. Contract variables include the contract amount and maturity. Firm variables include proxies for firm investment opportunities, profitability, size, asset tangibility, liquidity, financial leverage, and credit risk, in addition to its borrowing history. The 
proxy for bank credit supply conditions is the Federal Reserve's Senior Loan Officer Opinion Survey (SLOOS) index, which reflects changes in C\&I tightening standards for large and middlemarket firms.

Panel A of Table 4 reports the results of the logistic regression for the Base Model; and Panel B, for the Full Model. During the 2004-2006 pre-crisis years, larger and more liquid firms, and firms with higher credit risk were more likely to secure bank debt than to issue bonds. The persistence of borrowing is denoted by a 5-year debt funding history dummy variable; firms that obtained loans (bonds) in the past continued to do so in subsequent years. During the crisis years, most of the coefficient signs are consistent with those from pre-crisis years, but the magnitudes and statistical significances differ. Bank loans were larger in amount, shorter in maturity, and extended even to firms with weak credit ratings. In addition, firms with a history of bank debt funding were still more likely to obtain bank credit during the crisis but the coefficient is statistically insignificant for 2008. In most years, an increase in tightening standards reduced the likelihood that firms acquire bank loans but the coefficient is statistically significant only in 2008.

\section{[Insert Table 4 here.]}

Estimated coefficients from the logistic model for the 2004-2006 pre-crisis years, as well as coefficients from the logistic models estimated for each year between 2004 and 2011, are used to compute the probabilities that firms will either obtain loans or issue bonds. Specifically, the odds ratio is $p / q=e^{\alpha+\gamma C+\varphi F+\psi S+\varepsilon}$, and because $p+q=1$, it follows that $p=(p / q) /(1+p / q)$, where $p$ and $q$ are the estimated probabilities that an observed contract-firm pair corresponds to loan or bond financing, respectively. Excess probabilities for the Base Model are then computed as $\left(p_{t}-p_{2004-2006} \mid \boldsymbol{C}, \boldsymbol{F}\right)$, and for the Full Model as $\left(p_{t}-p_{2004-2006} \mid \boldsymbol{C}, \boldsymbol{F}, S\right)$.

Table 5 reports average excess probabilities by model, contract type, and year. Top and 
bottom portions of the table present the Base Model and Full Model results; left-hand and righthand columns report excess probabilities for obtaining bank loans and issuing bonds. The Base Model shows a lower likelihood of securing a bank loan of 8\% (10\%) in 2008 (2009) compared with pre-crisis years 2004-2006. Similarly, the probability of securing bond financing of $28 \%$ (36\%) is higher in 2008 (2009) compared with pre-crisis years 2004-2006. The aggregate excess probability measures are significantly different from zero at the $1 \%$ level.

\section{[Insert Table 5 here.]}

Bank credit supply conditions played an important part in explaining debt funding outcomes, especially in 2008. In the Full Model, the likelihood that a firm will secure a bank loan in 2008 (2009) fell by 4\% (9\%). An increase in tightening standards by banks in the crisis year 2008 accounted for half of the reduced likelihood of obtaining a bank loan by an otherwise similar firm. In contrast, the likelihood of acquiring bond financing in crisis years rose considerably by 19\% (27\%) in 2008 (2009). Overall, the results support the hypothesis that changes in the supply of bank credit during the financial crisis encouraged many firms to migrate to the public debt market. $^{12}$

${ }^{12}$ Our excess probability tests assume that the specific yearly distribution of contracts reflects underlying credit conditions and is not simply a product of chance. Consider for a moment this assumption is incorrect. Then any random temporal distribution of the contracts could potentially yield excess probability results that resemble those presented in Table 5. We test this possibility by randomly assigning observations (debt contracts) to each year. Next, we estimate the prediction models, and compute the normal, imputed, and excess probabilities in the same fashion as in Tables 


\section{Bank Distress, Liquidity Growth, and Credit Supply}

As Edlin and Jaffee (2009) observe, the contraction in bank credit during the crisis was coincident with an extraordinary accumulation of bank excess reserves held at the Federal Reserve following governmental asset relief programs that infused significant liquidity into the banking system. The uncharacteristically high levels of excess reserves, we argue, is symptomatic of liquidity hoarding during the crisis in response to a heightened threat of insolvency particularly for distressed banks. Cornett, McNutt, Strahan, and Tehranian (2011) find that banks with high liquidity risk exposure at the onset of the crisis subsequently increased liquidity and contracted credit during the crisis. The accumulation of liquidity not only slowed asset growth and assisted banks in satisfying regulatory capital requirements but also allowed banks to fund cash drawdowns from outstanding loan commitments as well as wholesale funding withdrawals. We include in this subsection a first examination to the effect of bank distress on liquidity growth and credit contraction.

We use expected default frequency (EDF) to proxy for insolvency risk. Distance to default (DD) is the difference between the firm's market value of assets and its liabilities payable within one period, divided by a one standard deviation change in the market value of assets. The market value of assets and the volatility of assets returns are, however, not directly observable.

4 and 5. We repeat this experiment 100 times (we also ran trials of 1,000 and 10,000) and capture the mean excess probability by year, contract type, and trial. Table A.1 in the Appendix reports the average of the mean excess probability and standard error across the 100 trials. None of the mean excess probability estimates are statistically different from zero. This finding shows that our results are unlikely to be driven by chance. 
Recognizing that equity is a call option on the underlying market value of a firm, we can use option pricing models to compute a firm's DD solely from a firm's market value of equity, equity volatility, and book value of debt (Merton, 1974). Higher values of DD imply lower default probabilities. Applying a probability distribution to DD yields the EDF. As described by Crosbie and Bohn (2003), we use the Black-Sholes option pricing model and translate one year DD into EDFs using a normal distribution. ${ }^{13}$

We explore the influence of bank distress on liquidity and loan growth with a series of univariate OLS regressions. The primary explanatory variable is EDF at time $t$, and the primary dependent variables are quarterly liquidity and loan growth rates in the subsequent period $(t$ to $t+1)$. Liquidity is defined as cash and balances due from depository institutions plus securities, Federal Funds sold, and securities purchased under agreements to resell. The regression sample includes all BHCs that filed FR Y-9C regulatory reports between 2004 and 2011. Table 6 reports the regression results across three different time periods. Note that each coefficient represents a unique regression. Intercepts are not reported.

${ }^{13}$ Note that our EDF estimates differ from those of KMV because KMV uses a proprietary option pricing model and an historical default dataset to map distance to default into EDF. We compute equity volatility using 12 lagged monthly returns. We follow Vassalou and Xing (2004) and Bharath and Shumway (2008) and define the relevant portion of liabilities to be debt in current liabilities plus one-half of long term debt. Also as in Bharath and Shumway (2008), we seed the volatility of asset returns as a function of the volatility of equity returns and the ratio of equity to assets. Quarterly accounting data come from Compustat, and monthly stock price data are from CRSP. 
[Insert Table 6 Here]

Table 6 reveals three key patterns. First, only in the crisis period do banks with higher EDFs increase liquidity growth. In both the pre-crisis and post-crisis periods, higher EDF lowered liquidity growth. Because average EDF values were exceptionally high in the crisis period, the impetus to accumulate liquidity was likely more critical than in other periods. Second, loan creation is always negatively related to bank distress in prior periods and the adverse impact of bank distress is larger in magnitude and more significant during crisis. Third, although loan and liquidity growth are contemporaneously unrelated in the pre-crisis period, the relation is negative and significant during the crisis and post-crisis periods. Taken together, the evidence suggests that in crisis periods when insolvency and systemic risks are high, distressed banks reduce credit and accumulate liquidity as precautionary measures (Strahan, 2010) until the crisis ebbs and capital can be restored though profits and share issuances. Interestingly, asset growth is negative following a period of bank distress because the contractionary effects of loan chargeoffs and credit tightening outweigh a bank's efforts to accumulate liquidity.

\section{Lead Arranger Condition and Borrower Migration}

\section{a. Bank Distress}

In this subsection, we provide direct evidence for the bank lending channel by linking a firm's debt funding outcome to the distress of its lead bank. Banks are defined as lead banks if they receive lead arranger credit in DealScan or their roles in the syndication match a list of bank roles identified by Ivanshina (2009) as lead banks. These roles are administrative agent, agent, arranger, bookrunner, lead arranger, lead bank, and lead manager. We hand match each lead bank in the DealScan database with the ultimate parent bank holding company extending the loan using the organizational data from the Federal Financial Institutions Examination Council's National 
Information Center website. A relatively small number of observations where a loan deal has more than one lead arranger is excluded to capture the undiluted effect of borrowing relationships with distressed and healthy banks on debt funding outcomes.

We estimate multinomial logit regressions to assess the impact of firm attributes, overall banking industry distress, and lead bank distress on a firm's debt funding outcome. Each regression takes the following form:

$$
\text { Borrowing Outcome }_{i, t+1}=\alpha+\varphi \boldsymbol{F}_{i t}+\xi B_{t+1}+\gamma b_{l, t+1}+\varepsilon_{i, t+1}
$$

Where $\alpha$ is a constant term, $\boldsymbol{F}_{i t}$ is a vector of firm $i$ controls at year $t, B_{t+1}$ is the banking industry distress proxy in year $t+1, b_{l, t+1}$ is the lead bank distress or liquidity at time $t+1$, and $\varepsilon$ is the error term. In (2), the debt funding outcomes of firms in year $t+1$ are conditional on firms obtaining bank loans in year $t$. The limited dependent variable takes on values of 1 to 4 representing a migration at $t+1$ to no debt, bank debt only, public debt only, or bank and public debt, respectively. ${ }^{14}$

The relatively few number of observations with complete data combined with the degrees of freedom required to estimate multinomial logit regressions make yearly cross-sectional regressions infeasible. Instead, we estimate pooled regressions over the 2004-2011 period which control for lead bank as well as banking industry conditions and cluster errors by firms. The financial health of lead banks and the banking industry in $t+l$ are measured using two alternative proxies of distress. Moreover, to ensure that cross-sectional variations in lead bank distress are uncorrelated with temporal changes in banking industry distress, we pay careful attention to

\footnotetext{
${ }^{14}$ We run a Test for Independence of Irrelevant Alternatives on these four outcomes and cannot reject the null that they are independent.
} 
eliminating any time trends from the lead bank distress measures.

The first proxy for a bank distress, EDF Bracket, is the annual average percentile bracket associated with the lead bank's EDF. For each month in the sample, we compute each bank's EDF and the EDFs in a given month are used to sort banks into 20 groups; each bracket contains $5 \%$ of the sample. Each bank is assigned a value of 1 to 20 with higher values corresponding to higher levels of lead bank distress. ${ }^{15}$ For each bank, we average the monthly EDF brackets each year. Because each bracket represents a percentile score, the annual EDF bracket value reflects a lead bank's relative distress in a given year and is unrelated to the overall industry EDF level.

The second proxy for a bank distress is a set of two dummy variables whose values depend on changes in a bank's $S \& P$ long-term issuer credit rating from one year to the next. For each pair of years $(t, t+1)$, we compute the annual average rating at $t$ and the annual average rating at $t+1$. Ratings Downgrade is a dummy variable that equals 1 if the average rating at $t+1$ is lower than the average rating at $t$, and 0 otherwise. Ratings Upgrade is a dummy variable that equals 1 if the average rating at $t+1$ is higher than the average rating at $t$, and 0 otherwise. We treat bank downgrades and upgrades separately because their effects on a firms' debt funding outcomes are likely to be asymmetric. Although we can expect a downgrade will significantly limit a bank's

${ }^{15}$ Sorting bank EDFs into 20 brackets parallels the categorization of ratings. Like ratings, this approach does not assume a monotonic relationship between bank EDF and distress. We also used bank EDFs directly without sorting, as well as changes in bank EDF between pre-crisis and crisis periods, as alternative distress proxies. Additionally, we considered the maximum annual EDF instead of the annual average. In all cases, these alternative distress measures produce results qualitatively similar to the ones we report here. 
ability to extend new credit, it is unlikely that an upgrade will significantly stimulate bank lending. Ideally, we would use the absolute change in a lead bank's rating between $t$ and $t+1$ as the distress measure rather than dummy variables. The relative severity of downgrades in 2008 and 2009, however, causes the temporal averages in ratings changes to be correlated with overall banking industry distress.

In addition to controlling for individual lead bank distress, we also account for aggregate banking industry distress using two alternative proxies based on EDF and $S \& P$ ratings changes. Industry EDF is the average EDF value across all BHCs for which EDFs can be computed, and Industry Ratings Change is the average change in $S \& P$ ratings across all $\mathrm{BHCs}$ with ratings. As expected, these proxies for banking industry distress are highly correlated.

The influence of a bank lending channel on debt funding outcomes should be most prevalent when banks are acutely distressed; that is, we expect $b_{l}$ to affect debt funding outcomes only during the crisis years. Interacting $b_{l}$ with year dummies in 2008 and 2009 captures the impact of the crisis. For firms that borrowed from a lead bank in a given year $t$, the coefficient on $b_{l}$ for EDF Bracket or Ratings Downgrade, embodies the average effect of lead-bank distress on debt funding outcomes across all the years; the coefficient on the interaction $b_{l} \times 2008$ (2009) embodies the marginal effect of the lead bank's distress only in 2008 (2009). F-statistics on the sum of the lead bank average and marginal coefficients in a given year, $b_{l}+b_{l} \times 2008(2009)$, are used to test whether the total effects of lead bank distress are statistically significant in that year.

The multinomial logit regression results are reported in Table 7. Firms that migrate from bank debt at $t$ to bank debt only at $t+1$ serve as the reference funding outcome. The first three columns report results from Model (1), which uses EDF as the proxy for banking industry and lead bank distress. In column (1), the limited dependent value equals 1 if a borrower migrated from 
bank debt in $t$ to no debt in $t+1$, and 0 if the borrower continued to borrow bank debt in $t+1$. Firm attribute variables indicate that firms more likely to migrate to no debt in $t+1$ have lower ROA, fewer fixed assets, less financial debt, no recent history of securing a revolving loan from a bank, no credit rating, and higher cash holdings - a result consistent with Kahle and Stulz (2013) who suggest firms relied heavily on internal financing during the crisis. Banking industry conditions matter as well. Higher banking industry EDF increases the likelihood that a firm migrates from bank debt at $t$ to no debt at $t+1$.

\section{[Insert Table 7 here.]}

The key result in column (1) is that firms who borrowed in 2007 from lead banks that became distressed in 2008 were even more likely not to secure debt during that year. The statistically significant coefficient of 0.048 is direct evidence that a bank lending channel contributed to the credit crunch in 2008. This result complements evidence from Santos (2011) and Gambacorta and Marques-Ibanez (2011). Santos (2011) shows that banks with higher chargeoffs created smaller loan contracts during this period. Gambacorta and Marques-Ibanez (2011) analyze a sample of banks from 15 countries (including the United States) and show that during the crisis banks with higher expected default frequencies had lower growth rates of balance sheet loans.

Interestingly, the positive but statistically insignificant coefficient on EDF Bracket $x 2009$ suggests that the bank credit crunch was short-lived, perhaps because of the extensive government stabilization policy interventions begun in October 2008.

Column (2) considers the migration of firms from bank debt at $t$ to public debt at $t+1$. Firms more likely to migrate to public debt at $t+1$ have higher ROA, more assets, higher asset tangibility, lower financial leverage, recent experience tapping the public debt market, and an 
investment grade credit rating. The banking industry EDF coefficient is positive and statistically significant, reflecting an increased likelihood that firms migrate from bank debt to public debt. EDF Bracket average and marginal coefficients in 2008 are positive though statistically insignificant; however, the sum of the average and marginal coefficients, which captures the total effect of lead bank distress in 2008, is statistically significant. Lead bank distress contributed to the migration of firms to public debt in 2008.

The results in column (3), which reflect the migration of firms from bank debt at $t$ to securing both bank and public debt at $t+1$, are similar to those in column (2). Banking system distress is positively related to the likelihood that firms obtain a diversified package of bank and public debt funding. Lead bank distress also makes a diversified debt funding outcome more likely on average; the marginal effects in 2008 and 2009 are negative but statistically insignificant.

The results of Model 2, which use changes in the $S \& P$ credit ratings changes as proxies for banking industry and lead bank distress, are reported in columns 4-6 of Table 7. Results are generally consistent with those reported under Model 1 in terms of signs, coefficient estimates, and statistical significance. Banking industry ratings changes remain a significant determinant of the likelihood that firms migrate from bank debt at $t$ to no debt as well as to both bank and public debt. As with Model 1, the Ratings Downgrade x 2008 coefficient in column 4 is positive and statistically significant. Firms with relationships to more distressed lead banks are less likely to be successful in securing any debt funding. Ratings Downgrade $x 2009$ is positive but statistically insignificant; and the average and marginal coefficients sum for this year is also insignificant. Interestingly, in column 5, banking industry ratings changes only trigger a statistically insignificant 
migration to public debt. ${ }^{16}$

\section{b. Liquidity Hoarding}

As shown in Table 6, liquidity growth and loan creation are unrelated in the pre-crisis period, but negatively and significantly related in the crisis and post-crisis periods. The results substantiate our thesis that in normal times, liquidity does not impinge upon the willingness of banks to undertake the credit risks associated with loan creation. Rather, additions of liquid assets complement and support asset growth associated with lending. But in times of crisis, a heightened threat of insolvency incites banks to contract credit and expand liquidity. High liquidity growth, we will show, diminishes the likelihood that firms receive bank credit.

Recognizing that a bank's normal liquidity growth is driven by asset growth that is both bank-specific and industry-wide, we identify abnormal liquidity growth as the idiosyncratic deviation from the average cross-sectional liquidity growth controlling for asset growth. We refer to this abnormal liquidity growth as liquidity hoarding. As in Table 6, liquidity is defined as cash and balances due from depository institutions plus securities, Federal Funds sold, and securities purchased under agreements to resell. Further, to account for possible seasonal effects in bank liquidity needs, we compute liquidity growth as the quarterly year-over-year percent change; asset

\footnotetext{
16 Two comments apply here. First, this coefficient is significant at $10 \%$ using a one-tailed test under the null hypothesis, which is better aligned with our conjecture, that "banking industry distress does not increase (as opposed to does not affect) the probability of migration". Second, from the average transition matrices in Panel $\mathrm{C}$ of Table 2, we know this outcome in the multinomial regression is particularly challenged by sample size. A larger sample size will likely reduce standard errors and strengthen the results of tests on coefficient significance.
} 
growth is computed similarly.

Using data from FR Y-9C reports of bank holding companies, each quarter between 2004 and 2011 we estimate a cross-sectional regression of the form:

$$
\text { Liquidity Growth }_{i}=\propto+\beta \text { Asset Growth } \text { Gr }_{i}+\varepsilon_{i}
$$

$\hat{\mu}_{i}=\widehat{\alpha}+\hat{\beta}$ Asset Growth $_{i}$ characterizes the quarterly predicted liquidity growth for bank $i$ after controlling for the cross-sectional marginal effect of asset growth on liquidity growth and a constant term. Our proxy for bank $i$ 's liquidity hoarding is $\varepsilon_{i}=$ Liquidity $G r o w t h_{i}-\hat{\mu}_{i}$, which is the cross-sectional mean-zero idiosyncratic component of liquidity growth. ${ }^{17}$

The multinomial logit regression Models 3 and 4 reported in Table 7 test the hypothesis that changes in the liquidity holdings of lead banks contributed to a credit contraction during the crisis. Model 3 uses EDF as the control for banking industry distress; Model 4 uses $S \& P$ ratings changes instead. The change in lead bank liquidity variable is the annual average of quarterly values. Like Models 1 and 2, we include an average effect and marginal effects for 2008 and 2009.

In Columns 1 and 4 of Models 3 and 4, the respective coefficients -0.164 and -0.174 associated with changes in lead bank liquidity, indicate that in normal times high liquidity growth accommodates the ability of banks to expand credit and reduces the likelihood that firms will not be able to secure debt funding. In 2008, the respective marginal lead bank liquidity-year coefficients are 2.114 and 2.792. The respective coefficient sums of1.950 and 2.618, which

\footnotetext{
${ }^{17}$ We also consider an alternative proxy for liquidity hoarding as the regression residual in (3) where the covariate is the growth rate in total assets net of liquid assets since liquid assets constitute a part of total assets. Results are qualitatively the same as the ones reported here.
} 
capture the total effect of liquidity growth, are significantly different from 0 at the $5 \%$ and $1 \%$ levels. In crisis times, there is a higher likelihood that firms do not secure debt funding, consistent with our thesis that heightened insolvency risk constrains loan creation. Similarly, taking the average and marginal effects in 2009 together, higher lead bank liquidity prods firms to obtain public debt, but not a diversified portfolio of bank and public debt.

Taken together, Table 7 shows that the financial health of the banking system and idiosyncratic distress of banks in 2008 contributed to the severity of the corporate credit contraction during the crisis. ${ }^{18}$

\section{c. Bank Distress and Liquidity Hoarding}

\footnotetext{
${ }^{18}$ We point out that the possibility of survival bias from the disappearance of lead banks through
} our sample period is small. The survival bias is small because we track firms, not banks, over each two-year period. All that is required for an observation to be part of our tests is at least one data point from the disappearing bank during $t+1$. When the bank does not exist at all in $t+1$, the observation is excluded from the regression. Moreover, the survival bias, to the extent it exists, goes against finding evidence of a bank lending channel. A missing lead bank observation implies a higher $e x$-ante probability that the associated firm will not obtain a bank loan at $t+1$ precisely because the banking relationship is disrupted, biasing our results against finding statistically significant migration from bank debt towards other debt outcomes. Additionally, we require each firm to be in the universe of public firms from $t-1$ through $t+1$ to avoid misclassifying a firm disappearing at $t+1$ as a rationed out firm. Again, this is a conservative approach which potentially works against finding evidence of the bank lending channel; e.g. when a firm chooses to go private and as a result is rationed out. 
Table 6 shows that the relation between bank insolvency risk and subsequent liquidity growth becomes positive and significant during the financial crisis, coinciding with a significant reduction in loan creation. Because liquidity lessens the potential for a bank run on a distressed bank, we expect more distressed banks to hoard more liquidity during a crisis. We use our measure of liquidity hoarding to test this hypothesis. For every quarter $t$ in our sample, we estimated the following cross-sectional regression:

$$
\varepsilon_{i, t}=\gamma+\phi E D F_{i, t-3}+v_{i, t}
$$

Where $\gamma$ is a constant term, $E D F_{i, t-3}$ is the three-month lagged expected default frequency bracket of bank $i$, and $v_{i, t}$ is the error term. $\phi$ is the cross-sectional marginal effect of bank distress on subsequent liquidity hoarding, our parameter of interest. Figure 2 presents the estimates of $\phi$ and the $95 \%$ confidence intervals through time and shows that bank distress induces liquidity hoarding during the crisis.

\section{E. EFFECT OF LOAN CONTRACTION ON CORPORATE INVESTMENT}

In this section, we examine the effect of a contraction in bank credit supply on firm investment. If some portion of the impact on the real economy from the crisis is through the bank lending channel, then bank-dependent borrowers will decrease investment when banks curtail lending because financing through public bond issues is not an option. In time, reduced investment intensifies downward pressures on economic growth.

The impact on corporate investment of bank credit contraction during the crisis should be most evident for firms that initially borrowed from a bank and were subsequently unsuccessful in securing any debt financing. We define corporate investment as capital expenditures to total 
assets. ${ }^{19}$ Summary statistics on corporate investment of firms that obtained bank debt at $t$ and did not borrow during $t+1$, classified by year and the financial fragility of its lead banks, is presented in Table 8. We expect investment rates to be lower during the crisis years for firms with relationships with distressed lenders because it is more likely they were denied credit despite having otherwise similarly acceptable investment opportunities. For this table only, we classified lead banks as distressed if their $S \& P$ long term domestic issuer credit rating was downgraded more than the median downgrade for BHCs during the financial crisis. The key rows in Table 8 are $t+1=2008$ and $t+1=2009$.

[Insert Table 8 here.]

As expected, capital investment was lower for firms that borrowed from distressed lead banks. In 2008, investment was 70 basis points lower than for firms that borrowed from banks that were not distressed, but the difference is not statistically significant. In 2009, the gap widened to 90 basis points, and the difference is significant at the $11 \%$ level. A complete reversal in 2010 suggests the impact of credit contraction on investment was short-lived.

Table 9 reports the results of least-squares regressions of capital expenditure to assets during $t+1$ on firm characteristics at $t$ and proxies of lead bank distress or liquidity at $t+1$ for firms that borrowed bank debt in period $t$ from a unique lead bank. ${ }^{20}$ The general model has the

\footnotetext{
${ }^{19}$ In unreported results we define investment as the ratio of capital expenditures to lagged total assets. Our results remain qualitatively unchanged.

${ }^{20}$ Firms that borrowed both bank and public debt are in the regression sample as well, as long as they had a unique lead bank lender at $t$. In unreported tests, we ran the regressions on the
} 
following form:

$$
\text { Investment }_{i, t+1}=\alpha+\varphi \boldsymbol{F}_{i, t}+\mu \boldsymbol{M}_{i, t+1}+\gamma b_{l, t+1}+\tau \boldsymbol{Y}_{\boldsymbol{t + 1}}+\varepsilon_{i, t+1}
$$

Where $\alpha$ is a constant term, $\boldsymbol{F}_{i, t}$ is a vector of controls for firm $i$ and for year $t, \boldsymbol{M}_{i, t+l}$ is a vector representing whether the firm migrates to no debt, bank debt, public debt, or both bank and public debt during period $t+1, b_{l, t+1}$ is a proxy of lead bank distress or liquidity during $t+1, Y$ is a vector of year fixed effects, and $\varepsilon_{i, t+1}$ is the error term. The reference outcome is the set of firms that borrowed bank debt in period $t$ and continued to borrow bank debt in $t+1$. Year fixed effects control for unobserved macroeconomic conditions that affect firm investment.

We present six model specifications. Models 1, 2, 4, and 5 focus on the impact of lead bank distress on firm investment, and Models 3 and 6 focus on the impact of bank liquidity hoarding. Models 1 and 4 use the lead bank's EDF Bracket as the distress proxy, and Models 2 and 5 use Ratings Downgrade. Additionally, Models 1 and 2 include both the average effect of the bank's distress on firm investment, and the marginal effect for years 2008 and 2009. Models 4 and 5 present only the average effects of bank distress over the entire sample period.

[Insert Table 9 here.]

The results support the hypothesis that lead bank distress reduced firm investment. The EDF Bracket $x 2008$ coefficient of 0.019 in Model 1 is insignificant, but the Ratings Downgrade $x 2008$ coefficient of -0.668 in Model 2 is statistically significant. Further, the EDF Bracket $x$ 2009 coefficient of -0.123 in Model 1 and the Ratings Downgrade $x 2009$ coefficient of -1.273 in

subsample of firms that only borrowed bank debt during period $t$. The results remain qualitatively unchanged. 
Model 2 are both statistically significant at the $1 \%$ level.

A firm's debt funding outcome in year $t+1$ also affects investment across all the model specifications. ${ }^{21}$ Relative to firms that continue to borrow from banks in $t+1$, firms that do not borrow at all reduce investment by about 43 basis points. There is no statistically significant change in investment for firms that migrate to public debt, but a statistically significant increase in investment of more than 1.5 percentage points for firms that migrated to a diversified funding package of bank and public debt. These results highlight the importance of financial flexibility, which enabled firms to avoid many of the adverse consequences of a contraction in bank lending. Further, the large positive and statistically significant coefficient on cash balances suggests that the access of firms to internal funding provided strong support for investment.

Models 4 and 5 exclude the marginal distress variables in 2008 and 2009. The EDF Bracket coefficients in Models 1 and 4 are both close to zero and statistically insignificant; average effects are uncorrelated with marginal effects in crisis years. Note however that the Ratings Downgrade coefficient -0.699 in Model 5 is nearly three times larger in magnitude than the equivalent coefficient of -0.242 in Model 2 and the difference is significant at the $1 \%$ level. Bank

${ }^{21}$ Our interpretation of the migration coefficients should be qualified. Borrowing outcomes are introduced as explanatory variables in order to assess the impact of credit supply conditions on corporate investment. There is, however, a potential endogeneity between the decisions of firms to invest/borrow and the quality of their investment opportunities. For instance, all things equal, a firm with poorer investment opportunities will be more likely to both invest less, and as a consequence, choose a no debt outcome in $t+1$. Although we do control for investment opportunities through a lagged $Q$, this proxy might not be sufficient to eliminate endogeneity. 
distress had a distinctly significant adverse impact on firm investment.

We approximate the effect of the bank lending channel on investment and GDP in 2009, recognizing of course, that any point estimate is subject to wide forecasting errors. Kahle and Stultz's (2013) observe that the significant decline in investment occurred in 2009 since many investment projects were well underway when the crisis peaked in September 2008. Moreover, Campello, Graham, and Harvey (2010) document that CFOs in credit constrained companies planned significant cuts in investment for 2009. Our Table 9 result substantiates that lead bank distress had a statistically significant impact on investment in 2009. Estimating Model 1 as a crosssectional regression for the year 2009 yields an EDF Bracket coefficient of -0.155 , which implies that, all else equal, a firm's investment rate declines by 15.5 basis points when its lead bank's EDF percentile grouping moves one bracket higher. EDF Bracket=0 represents a lead bank with no distress, and the estimated investment rate for firms borrowing from this group of banks is $6.59 \%$. Moreover, because investment rates decline by an additional 15.5 basis points for each increase in $E D F$ Bracket, the expected decline in the investment rate for a given bracket is simply EDF Bracket*(-15.5bp). For each bracket, the anticipated decline in investment rate is multiplied by the percentage of sample firms with lead banks in that particular bracket. Summing the values across the brackets yields $-1.59 \%$ as the predicted reduction in the rate of investment in 2009 due to bank distress.

For our sample of firms, a decrease of 1.59 percentage points in the ratio of capital expenditures to 1-year lagged assets denotes a reduction in investment of $\$ 27.2$ billion in 2009 , or a $25.6 \%$ decline from the amount of investment undertaken in 2008. Table 2 shows that about $50 \%$ of firms in our sample originate bank loans in a typical non-crisis year. Hence the $25.6 \%$ decline in investment of half the firms translates to a reduction of $12.8 \%$ in 2009 nonresidential 
fixed investment, representing about $82.1 \%$ of the decline in nonresidential fixed investment in $2009 .{ }^{22}$ Further, since nonresidential fixed investment in 2008 accounted for $13 \%$ of GDP, an educated guess of the 2009 decline in GDP from the bank lending channel is $1.67 \%$, or $59.6 \%$ of the $2.8 \%$ GDP contraction in $2009 .{ }^{23}$

Despite the economically large point estimate of the bank lending channel, our estimate may be downward biased for two reasons. First, the firms in our sample are large and publicly traded; small and medium sized businesses that are more dependent on bank credit surely experienced a larger decline in investment from a contraction in bank credit. Second, our analysis focuses only on corporate credit. Given the deterioration in household balance sheets from the housing crisis, many creditworthy households would have been denied credit by distressed banks as well, which would reduce consumption and residential investment.

Finally, we analyze the impact of lead bank liquidity hoarding on firm investment. Model 3 of Table 9 includes both an average effect and marginal effects for 2008 and 2009; and Model 6 includes only an average effect. The average effect coefficients, 2.952 and 2.399 in Models 3 and 6 respectively, are positive and statistically significant. Higher bank liquidity accommodates higher loan creation that facilitate higher levels of investment by firms. Model 3 shows that the

${ }^{22}$ Federal Reserve Economic Data series PNFICA "Real Private Nonresidential Fixed Investment.”

23 Federal Reserve Economic Data series PNFICA "Real Private Nonresidential Fixed Investment" and GDPCA "Real Gross Domestic Product." We considered several other scenarios as robustness checks, with consistent results. Importantly, the point estimate from the Ratings Downgrade coefficient in the 2009 cross-sectional regression is 63\% of the decline in GDP. 
interacted bank liquidity hoarding measure for 2008 is close to zero and insignificant, while for 2009 it is negative, large, and significant at $1 \%$ level. Liquidity hoarding resulted in loan contraction and this contraction in bank credit reduced corporate investment in 2009. The combined average and marginal effects, which are positive and significant, lend credence to the argument that significant infusions of liquidity helped to prevent a banking system failure that might have triggered another Great Depression.

\section{F. SUPPLY CURVE SHIFT OR CREDIT RATIONING?}

Credit rationing to enhance liquidity is a rational response for distressed banks that seek to reduce the risk of a run when there is little or no opportunity to raise capital at a reasonable cost and the requisite time needed to effect a reduction in its loan volume through higher interest rates is lacking. Creditworthy firms who wish to borrow from banks at prevailing interest rates are denied loans. In this section, we present evidence which shows that banks as a whole chose to reduce lending through volume adjustments rather than through higher rates of interest during the crisis.

Anecdotal evidence abounds consistent with banks rationing credit. News media surrounding the crisis suggests that many firms, encountering difficulties in obtaining bank loans, borrowed through public bond issues despite considerably higher rates in the public debt market than in the loans market.

One firm that issued a five-year note at the height of the crisis was El Paso Corporation, a natural gas producer, which operates a large pipeline system. On December 09, 2008, Ms. Dena Aubin of Reuters quoted Mr. Andy DeVries, an analyst at Credit Sights, as saying "El Paso is facing large funding needs, including about \$US900 million of debt coming due next year." Reporting on this deal, Mr. Bryan Keogh of Bloomberg quoted Mr. Jill Fields, a managing director 
at Babson Capital Management LLC, as saying "More high-yield companies may come to the market in the coming months to refinance debt that will mature in 2009 because banks don't have a lot of liquidity to offer... Good companies will have access to the market, especially if yields are attractive."

Altria Group Inc., a tobacco industry leader, entered into a syndicated bridge loan agreement on December 19, 2008 to partially finance the acquisition of UST Inc., a leader in the smokeless tobacco market. The loan amount was \$US4.3 billion with a maturity of 12 months, at LIBOR +225 basis points or a yield of roughly $4.7 \%$. But a day earlier, on December 18, 2008, the firm issued \$US775 million in notes maturing in 18 months and at a 7.125\% yield, a cost considerably higher than on the syndicated loan. If the firm had had unrestricted access to bank funding, it seems safe to assume securing the extra \$US755 million at $4.7 \%$ from banks would have been preferable.

If credit contraction is an equilibrium outcome, the quantity of loans demanded and supplied should be equal at the prevailing interest rate. Yield spread stickiness, reflected in yield spread differences between bank loans and public bonds, concomitant with a surge in the ratio of drawdowns under existing commitment to all drawdowns, are indicative of credit rationing.

Table 10 reports the results of yearly OLS regressions of yield spreads on bank loans and public debt. The general equation we use for contract $j$ of firm $i$ in year $t$ is as follows:

$$
\operatorname{Spread}_{j, t}=\alpha+\eta L_{j, t}+\gamma \boldsymbol{C}_{j, t}+\varphi \boldsymbol{F}_{i, t-1}+\varepsilon_{j, t}
$$

Where $\alpha$ is an intercept; $L_{j, t}$ is an indicator variable that takes a value of 1 if the contract $j$ of year $t$ is a bank loan, and 0 if it is a bond issue; $\boldsymbol{C}_{j, t}$ and $\boldsymbol{F}_{i, t-1}$ are vectors of contract and (lagged) firm characteristics, respectively; $\varepsilon_{j, t}$ is the error term. Spread, in basis points, is the difference between contract yield and a reference risk-free rate determined by matching maturities to the Treasury 
constant maturity rates. For bonds, contract yield is the offered yield to maturity. For fixed-rate bank loans, contract yield is the fixed rate; for floating-rate bank loans, yield is the sum of base rate, margin, and facility fees. ${ }^{24}$

For every month in our sample we create a 360-data point term structure for Treasury constant maturity and LIBOR rates to obtain parsimonious estimates of the contract yield spread. The raw data series contain somewhere between 11 and 16 data points for maturities ranging between 1 and 30 years. From these raw data points we construct term structures of monthly maturities using a natural growth rate function. Specifically, from two contiguous raw interest rates $i_{t}$ and $i_{T}$, where $t$ and $T$ stand for maturities measured in months and $\tau_{T}=T-t \geq 2$, we calculate the natural growth rate between them as $r=\ln \left[\left(i_{T} / i_{t}\right)^{1 / \tau_{T}}\right]$. Next we use the natural growth rate to interpolate interest rates in the term structure for all maturities ranging from $t+1$ to $T$-1; i.e., $i_{k}=i_{t} * \exp \left(r * \tau_{k}\right)$ where $\tau_{k}=k-t \geq 1$ and $\tau_{k}<\tau_{T}$. For those few contracts whose maturity is longer than 30 years, we use 30 -year interest rate estimates. ${ }^{25}$

\section{[Insert Table 10 here.]}

The results in Table 10 show that the cost of debt is consistently lower for more profitable

\footnotetext{
${ }^{24}$ The vast majority of syndicated bank loans employ LIBOR as the base rate and we restrict our analysis to these contracts. We use the all-in spread drawn when available, which is the amount the borrower pays over LIBOR for each dollar drawn.

${ }^{25}$ This simplification should not produce any significant bias given that these contracts represent only $0.58 \%$ of the sample and the term structure is typically flat between maturities of 30 and 50 years.
} 
firms and higher for firms with higher financial leverage. The coefficients on $S \& P$ ratings show that a one notch increase in the credit rating reduces the cost of debt by more than 20 basis points. Importantly, the coefficient on the bank loan indicator variable shows that the spreads between bank and public debt are not statistically different from each other in normal years. During the crisis years, however, banks lent at substantially lower interest rates than bond investors. For the years 2008 and 2009, yield spreads on bank loans were 137 and 68 basis points lower, respectively, consistent with interest rate stickiness, a stylized feature associated with bank credit rationing.

Loan commitment drawdowns also suggest that credit rationing played a role during the crisis. As Berger and Udell (1992) note, when banks ration credit, the pace at which firms will draw on existing loan commitments will exceed the pace of new loan originations. Consequently, the proportion of drawdowns under existing commitments to all drawdowns will rise. Furthermore, the increased proportion of drawdowns under existing commitments will coincide with higher open market interest rates.

Using data from the Federal Reserve Board of Governors Survey of Terms of Business Lending, we plot in Figure 3 for 2006 through 2010, the quarterly loan commitment drawdown ratio, which is all commercial and industrial $(\mathrm{C} \& \mathrm{I})$ loans originated by domestic banks under commitment where the loan terms and pricing were set more than 365 days in the past, divided by all C\&I loans originated by domestic banks. The ratio hit a trough in November 2006 and trended upward through February 2010, consistent with credit rationing. As banks became reluctant to book new credits, firms took advantage of existing lines to meet liquidity needs. The increase in the loan commitment drawdown ratio effectively coincided with rising rates on bond issues, as illustrated by the Moody's Baa spread over Treasuries. From Table 10, we know the average yield spread on bank loans rose by a smaller magnitude than on public bonds in crisis years. Firms 
without existing commitments were forced to go to the more expensive public bond issue market for financing, or be left out without credit. The evidence strongly suggests that banks did not use increases in the interest rates to clear the loan market during the crisis years of 2008 and 2009.

[Insert Figure 3 here.]

We established that yield spreads on bank and public debt increased during the crisis, but the rise in yield spreads on public debt were significantly greater. We also expect to observe loan pricing heterogeneity across banks. If higher liquidity is a safeguard against a heightened insolvency risk during the crisis, relatively higher needs for liquidity at distressed banks should lead them to increase yield spreads more than healthier banks. Santos (2011) documents that banks with higher chargeoffs during the financial crisis lent at higher spreads.

[Insert Table 11 here.]

Controlling for contract and borrower attributes, Table 11 reports the results of regressions of syndicated loan yield spreads on lead bank distress three months prior to loan origination as well as lead bank liquidity hoarding in the same quarter the loan is originated. Columns (1) and (2) show that EDF has no statistically significant effect on yield spreads pre-crisis, but during the crisis, banks with higher EDFs charged higher yield spreads. Columns (3) and (4) show similar results for Ratings Change. Recall that positive (negative) changes in lead bank's $S \& P$ domestic long-term issuer credit rating fifteen and three months prior to the syndicated loan origination are associated with downgrades (upgrades). Banks with more severe ratings downgrades charged higher yield spreads. Specifically, a one-notch downgrade resulted in 32 basis point higher yield spreads. Finally, the positive and significant coefficients on lead bank liquidity hoarding in Columns (5) and (6) indicate that higher abnormal growth in lead bank liquidity resulted in higher costs of credit to borrowers. Furthermore, the magnitudes of the coefficients show that yield 
spreads are 3.5 times more sensitive to changes in lead bank liquidity during the crisis than precrisis periods.

\section{G. CONCLUSION}

We examine the empirical significance of the bank lending channel on corporate credit and investment during the financial crisis that peaked in late 2008 and early 2009. We show that banks reduced their supply of credit in the crisis years to conserve liquidity. Many publicly traded firms with credit ratings were able to migrate to the public debt market, but many other firms were left without access to credit. Moreover, firms with lead banks that became distressed relative to other banks were even more likely to migrate or to lose access to credit altogether, direct evidence of the adverse consequences of bank credit contraction. Furthermore, firms that were shut out of credit markets experienced the largest reduction in investment, which contributed to the severity of the Great Recession, especially in 2009. The result was an economy that in 2014 is still healing from the crisis induced downturn in 2008.

Clearly the bank lending channel remains important in crisis because loans and bonds are not perfect substitutes. The ability of many publicly traded firms to promptly disintermediate and issue their own debt, however, provided important financial flexibility that allowed firms to withstand financial shocks to the banking sector. This flexibility makes the U.S. economy less dependent on bank financing than during the Great Depression, which all things equal, reduces the systemic risk that banking crises have on the U.S. economy. 


\section{H. REFERENCES}

Acharya, Viral, Hyun S. Shin, and Tanju Yorulmazer, 2011, Crisis Resolution and Bank Liquidity, Review of Financial Studies 24, 2166-2205.

Acharya, Viral V. and David Skeie, 2011, A Model of Liquidity Hoarding and Term Premia in Inter-Bank Markets, Journal of Monetary Economics 58, 436-447.

Ashcraft, Adam, 2005, Are Banks Really Special? New Evidence from the FDIC-Induced Failure of Healthy Banks, American Economic Review 95-5, 1712-1730.

Ashcraft, Adam, James McAndrews, and David Skeie, 2011, Precautionary Reserves and the Interbank Market, Journal of Money, Credit and Banking 43, 311-348.

Aubin, Dena, Tuesday December 09, 2008, El Paso Corp to sell debt, first junk bond since Oct, New York, Reuters. URL: http://www.reuters.com/article/2008/12/09/elpaso-bonds-saleidUSN0925384920081209.

Bharath, Sreedhar T. and Tyler Shumway, 2008, Forecasting Default with the Merton Distance to Default Model, Review of Financial Studies 21-3, 1339-1369.

Becker, Bo and Victoria Ivashina, 2014, Cyclicality of Credit Supply: Firm Level Evidence, Journal of Monetary Economics 62, 76-93.

Berger, Allen N. and Gregory Udell, 1992, Some Evidence on the Empirical Significance of Credit Rationing, Journal of Political Economy 100 1047-1077.

Bernanke, Ben S., 1983, Nonmonetary Effects of the Financial Crisis in the Propagation of the Great Depression, American Economic Review, 1983, 257-276.

Besanko, David and George Kanatas, 1993, Credit Market Equilibrium with Bank Monitoring and Moral Hazard, Review of Financial Studies 6-1, 213-232.

Bruno, Joe Bel, Matthias Rieker, and Marshall Eckblad, February 11, 2009, Bank Executives to Tell Congress: 'We're Lending', Wall Street Journal. URL: http://online.wsj.com/news/articles/SB123431547024070839

Caballero, R. and Krishnamurthy, A., 2008, Collective Risk Management in a Flight to Quality Episode, Journal of Finance 63 2195-2230.

Campello, Murillo, John R. Graham, and Harvey R. Campbell, 2010, The Real Effects of Financial Constraints: Evidence from a Financial Crisis, Journal of Financial Economics 97, 470487.

Cantillo, Miguel and Julian Wright, 2000, How Do Firms Choose Their Lenders? An Empirical Investigation, Review of Financial Studies 13-1, 155-189.

Chava, Sudheer and Amiyatosh Purnanandam, 2011, The effect of banking crisis on bankdependent borrowers, Journal of Financial Economics 99-1, 116-135. 
Chava, Sudheer and Michael R. Roberts, 2008, How Does Financing Impact Investment? The Role of Debt Covenants, Journal of Finance 63, 2085-2121.

Cornett, M., McNutt, J., Strahan, P., Tehranian, H., 2011, Liquidity risk management and credit supply in the financial crisis, Journal of Financial Economics 101, 297-312.

Crosbie, Peter and Jeff Bohn, 2003, Modeling Default Risk, KMV White Paper.

Denis, David J. and Vassil T. Mihov, 2003, The choice among bank debt, non-bank private debt, and public debt: evidence from new corporate borrowings, Journal of Financial Economics 70, 3-28.

De Fiore, Fiorella and Harold Uhlig, 2012, Corporate Debt Structure and the Financial Crisis, Working Paper.

Diamond, Douglas W., 1984, Financial Intermediation and Delegated Monitoring, Review of Economic Studies 51, 393-414.

Edlin, Aaron S. and Dwight Jaffee, 2009, Show Me The Money, Economists' Voice, 15.

Federal Reserve Economic Data, http://research.stlouisfed.org/

Gambacorta, Leonardo and David Marques-Ibanez, 2011, The Bank Lending Channel: Lessons from the Crisis, Economic Policy 26-66, 135-182.

Gan, J., 2007, The Real Effects of Asset Market Bubbles: Loan- and Firm-Level Evidence of a Lending Channel, The Review of Financial Studies 20-5, 1941-1973.

Gorton, Gary and Andrew Metrick, 2012, Securitized Banking and the Run on Repo, Journal of Financial Economics 104-3, 425-451.

Houston, Joel and Christopher James, 1996, Bank Information Monopolies and the Mix of Private and Public Debt Claims, Journal of Finance 51-5, 1863-1889.

Ivashina, Victoria, 2009, Asymmetric Information Effects on Loan Spreads, Journal of Financial Economics 92, 300-319.

Ivashina, Victoria and David Scharfstein, 2010, Bank Lending During the Financial Crisis of 2008, Journal of Financial Economics 97, 319-338.

Jiménez, Gabriel, Steven Ongena, José Luis Peydro, Jesus Saurina, 2012, Credit Supply and Monetary Policy: Identifying the Bank Balance-Sheet Channel with Loan Applications, American Economic Review, 102-5, 2301-2326.

Johnson, Shane A., 1997, An Empirical Analysis of the Determinants of Corporate Debt Ownership Structure, Journal of Financial and Quantitative Analysis 32-1, 47-69.

Kahle, Kathleen M. and Rene M. Stulz, 2013, Access to Capital, Investment, and the 
Financial Crisis. Journal of Financial Economics 110, 280-299.

Keeton, William R., 1979, Equilibrium Credit Rationing, New York, Garland Press.

Keogh, Bryan, Tuesday December 09, 2008, El Paso Raises \$500 Million in High-Yield Bond Sale (Update1), Bloomberg. http://www.bloomberg.com/apps/news?pid=newsarchive\&sid $=\mathrm{aTTkF} 8 \mathrm{abdV} 5 \mathrm{o} \& \mathrm{refer}=$ energy\#share.

Krishnaswami, Sudha, Paul A. Spindt, and Venkat Subramaniam, 1999, Information Asymmetry, Monitoring, and the Placement Structure of Corporate Debt, Journal of Financial Economics 51, 407-434.

Lemon, Michael and Michael R. Roberts, 2010, The Response of Corporate Financing and Investment to Changes in the Supply of Credit, Journal of Financial and Quantitative Analysis 45-3, 555-587.

Merton, Robert, 1974, On the Pricing of Corporate Debt: The Risk Structure of Interest Rates, Journal of Finance, 29, 449-470.

National Information Center, http://www.ffiec.gov/nicpubweb/nicweb/SearchForm.aspx

Rajan, Raghuram G., 1992, Insiders and Outsiders: The Choice between Informed and Arm's-Length Debt, Journal of Finance 47, 1367-1400.

Reinhart, Carmen and Kenneth Rogoff, 2009, This Time Is Different: Eight Centuries of Financial Folly. Princeton University Press.

Santos, Joao A. C., 2011, Bank Corporate Loan Pricing Following the Subprime Crisis, Review of Financial Studies 24-6, 1916-1943.

Sharpe, Steven A., Asymmetric Information, 1990, Bank Lending and Implicit Contracts: A Stylized Model of Customer Relationships, Journal of Finance 45, 1069-1087.

Steffy, Loren, Wednesday December 30, 2009, You Bail Me Out, I'll Bail You Out, Houston Chronicle, URL: http://www.chron.com/business/steffy/article/You-bail-me-out-I-llbail-you-out-1608424.php

Stigliz, Joseph E. and Andrew Weiss, 1981, Credit Rationing in Markets with Imperfect Information, American Economic Review 71, 393-410.

Strahan, Philip E., 2010, Liquidity Production in Twenty-First-Century Banking, on The Oxford Handbook of Banking, Edited by Allen N. Berger, Philip Molyneux, and John O. S. Wilson, 112-145.

Vassalou, Maria and Yuhang Xing, 2004, Default Risk in Equity Returns, Journal of Finance 59-2, 831-868. 
Table 1: Summary Statistics on Loan and Bond Contracts

Loans and bonds correspond to syndicated bank debt and public debt issues, respectively, by publicly traded non-financial firms. Data on syndicated bank debt, which span the period 2004 to 2011, were obtained from DealScan and on public debt issues from Thomson Reuters Securities Data Commission $(S D C)$ Global New Issues. ${ }^{\dagger},{ }^{\dagger \dagger}$, ${ }^{\dagger \dagger \dagger}$ denote annual averages by number of contracts, volume, and number of firms, respectively.

\section{Panel A}

\begin{tabular}{|c|c|c|c|c|c|c|c|c|}
\hline & \multicolumn{6}{|c|}{ Pre-Crisis } & \multirow{2}{*}{\multicolumn{2}{|c|}{$\begin{array}{c}\text { Transition } \\
2007\end{array}$}} \\
\hline & \multicolumn{2}{|c|}{2004} & \multicolumn{2}{|c|}{2005} & \multicolumn{2}{|c|}{2006} & & \\
\hline & Total & $\%$ & Total & $\%$ & Total & $\%$ & Total & $\%$ \\
\hline \multicolumn{9}{|l|}{ Contract Type $^{\dagger}$} \\
\hline Loan & 2,787 & $91 \%$ & 2,613 & $92 \%$ & 2,340 & $89 \%$ & 2,307 & $86 \%$ \\
\hline Bond & 291 & $9 \%$ & 236 & $8 \%$ & 287 & $11 \%$ & 363 & $14 \%$ \\
\hline Total & 3,078 & & 2,849 & & 2,627 & & 2,670 & \\
\hline \multicolumn{9}{|l|}{ Credit Volume $^{\dagger \dagger}(\$ B)$} \\
\hline Loans & 826 & $92 \%$ & 940 & $93 \%$ & 1,023 & $87 \%$ & 1,203 & $86 \%$ \\
\hline Bonds & 75 & $8 \%$ & 74 & $7 \%$ & 149 & $13 \%$ & 194 & $14 \%$ \\
\hline Total & 901 & & 1,015 & & 1,172 & & 1,397 & \\
\hline \multicolumn{9}{|l|}{ Firm Debt Choice ${ }^{\dagger \dagger \dagger}$} \\
\hline Loans Only & 1,543 & $92 \%$ & 1,393 & $91 \%$ & 1,288 & $89 \%$ & 1,167 & $86 \%$ \\
\hline Bonds Only & 46 & $3 \%$ & 47 & $3 \%$ & 71 & $5 \%$ & 80 & $6 \%$ \\
\hline Loans and Bonds & 90 & $5 \%$ & 85 & $6 \%$ & 95 & $7 \%$ & 108 & $8 \%$ \\
\hline Total & 1,679 & & 1,525 & & 1,454 & & 1,355 & \\
\hline Maturity (Months) & Loans & Bonds & Loans & Bonds & Loans & Bonds & Loans & Bonds \\
\hline Mean & 51 & 134 & 56 & 180 & 57 & 164 & 60 & 174 \\
\hline Standard deviation & 22 & 110 & 19 & 126 & 20 & 128 & 20 & 127 \\
\hline $25 \%$ percentile & 36 & 60 & 48 & 84 & 48 & 60 & 59 & 84 \\
\hline Median & 60 & 120 & 60 & 120 & 60 & 120 & 60 & 120 \\
\hline $75 \%$ percentile & 60 & 144 & 60 & 360 & 62 & 355 & 72 & 360 \\
\hline
\end{tabular}


Table 1: Summary Statistics on Loan and Bond Contracts (Cont.)

\begin{tabular}{|c|c|c|c|c|c|c|c|c|}
\hline & \multicolumn{4}{|c|}{ Panel A (Cont.) } & & & & \\
\hline & \multicolumn{4}{|c|}{ Crisis } & \multicolumn{4}{|c|}{ Post-Crisis } \\
\hline & \multicolumn{2}{|c|}{2008} & \multicolumn{2}{|c|}{2009} & \multicolumn{2}{|c|}{2010} & \multicolumn{2}{|c|}{2011} \\
\hline & Total & $\%$ & Total & $\%$ & Total & $\%$ & Total & $\%$ \\
\hline \multicolumn{9}{|l|}{ Contract Type $^{\dagger}$} \\
\hline Loan & 1,115 & $75 \%$ & 836 & $63 \%$ & 1,307 & $75 \%$ & 1,891 & $80 \%$ \\
\hline Bond & 366 & $25 \%$ & 485 & $37 \%$ & 439 & $25 \%$ & 486 & $20 \%$ \\
\hline Total & 1,481 & & 1,321 & & 1,746 & & 2,377 & \\
\hline \multicolumn{9}{|l|}{ Credit Volume $^{\dagger \dagger}(\$ B)$} \\
\hline Loans & 482 & $69 \%$ & 341 & $54 \%$ & 609 & $72 \%$ & 1,115 & $80 \%$ \\
\hline Bonds & 216 & $31 \%$ & 287 & $46 \%$ & 240 & $28 \%$ & 276 & $20 \%$ \\
\hline Total & 698 & & 627 & & 850 & & 1,392 & \\
\hline \multicolumn{9}{|l|}{ Firm Debt Choice ${ }^{\dagger \dagger \dagger}$} \\
\hline Loans Only & 690 & $78 \%$ & 518 & $65 \%$ & 757 & $74 \%$ & 1,069 & $82 \%$ \\
\hline Bonds Only & 129 & $15 \%$ & 199 & $25 \%$ & 160 & $16 \%$ & 70 & $5 \%$ \\
\hline Loans and Bonds & 62 & $7 \%$ & 78 & $10 \%$ & 107 & $10 \%$ & 165 & $13 \%$ \\
\hline Total & 881 & & 795 & & 1,024 & & 1,304 & \\
\hline Maturity (Months) & Loans & Bonds & Loans & Bonds & Loans & Bonds & Loans & Bonds \\
\hline Mean & 46 & 139 & 37 & 129 & 48 & 150 & 57 & 139 \\
\hline Standard deviation & 22 & 113 & 19 & 98 & 18 & 112 & 15 & 114 \\
\hline $25 \%$ percentile & 33 & 60 & 24 & 61 & 36 & 72 & 55 & 60 \\
\hline Median & 48 & 120 & 36 & 120 & 48 & 120 & 60 & 120 \\
\hline $75 \%$ percentile & 60 & 121 & 48 & 121 & 60 & 124 & 60 & 121 \\
\hline
\end{tabular}




\begin{tabular}{|c|c|c|c|c|c|c|c|c|}
\hline \multicolumn{9}{|c|}{ Panel B } \\
\hline & \multicolumn{4}{|c|}{ Pre-Crisis } & \multicolumn{4}{|c|}{ Transition } \\
\hline & \multicolumn{2}{|c|}{2004} & \multicolumn{2}{|c|}{2005} & \multicolumn{2}{|c|}{2006} & \multicolumn{2}{|c|}{2007} \\
\hline Credit Rating $\dagger$ & Total & $\%$ & Total & $\%$ & Total & $\%$ & Total & $\%$ \\
\hline $\mathrm{AA}-\sim \mathrm{AAA}$ & 71 & $41 \%$ & 58 & $71 \%$ & 54 & $54 \%$ & 56 & $59 \%$ \\
\hline $\mathrm{A}-\sim \mathrm{A}+$ & 282 & $67 \%$ & 241 & $65 \%$ & 214 & $58 \%$ & 243 & $47 \%$ \\
\hline BBB- $\sim \mathrm{BBB}+$ & 424 & $78 \%$ & 426 & $75 \%$ & 413 & $69 \%$ & 386 & $61 \%$ \\
\hline $\mathrm{BB}-\sim \mathrm{BB}+$ & 424 & $91 \%$ & 448 & $95 \%$ & 384 & $92 \%$ & 357 & $89 \%$ \\
\hline $\mathrm{B}-\sim \mathrm{B}+$ & 428 & $99 \%$ & 410 & $100 \%$ & 412 & $98 \%$ & 506 & $97 \%$ \\
\hline $\mathrm{CCC}-\sim \mathrm{CCC}+$ & 31 & $100 \%$ & 32 & $100 \%$ & 29 & $100 \%$ & 25 & $100 \%$ \\
\hline $\mathrm{D} \sim \mathrm{CC}$ & 6 & $100 \%$ & 2 & $100 \%$ & & & & \\
\hline Total & 1,666 & & 1,617 & & 1,506 & & 1,573 & \\
\hline Spread (basis & Loans & Bonds & Loans & Bonds & Loans & Bonds & Loans & Bonds \\
\hline $\mathrm{AA}-\sim \mathrm{AAA}$ & 51 & 59 & 94 & 74 & 94 & 77 & 97 & 102 \\
\hline $\mathrm{A}-\sim \mathrm{A}+$ & 82 & 75 & 95 & 78 & 89 & 93 & 94 & 130 \\
\hline BBB- $\sim \mathrm{BBB}+$ & 126 & 107 & 122 & 114 & 115 & 135 & 133 & 149 \\
\hline $\mathrm{BB}-\sim \mathrm{BB}+$ & 245 & 228 & 211 & 189 & 214 & 254 & 222 & 259 \\
\hline B- $\sim \mathrm{B}+$ & 341 & 451 & 317 & 543 & 323 & 338 & 324 & 352 \\
\hline $\mathrm{CCC}-\sim \mathrm{CCC}+$ & 538 & & 447 & & 407 & & 343 & \\
\hline $\mathrm{D} \sim \mathrm{CC}$ & 421 & & 796 & & & & & \\
\hline
\end{tabular}


Panel B (Cont.)

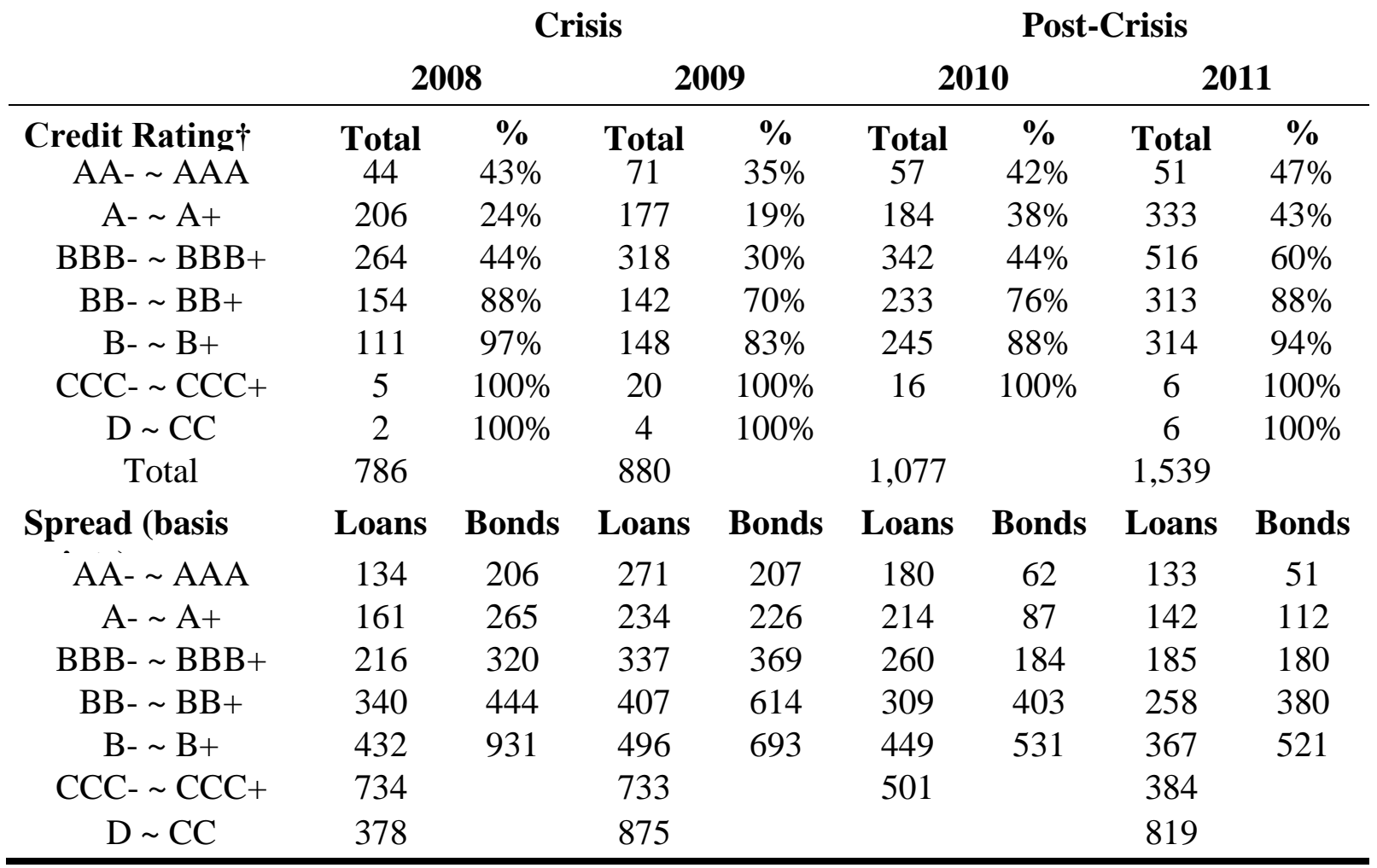




\section{Table 2: Transition Matrices of Debt Funding Outcomes}

Panel A reports the steady state distributions of syndicated bank and public debt issues imputed from transition matrices computed for each of six overlapping two-year periods between 2004 and 2010. Loans are syndicated bank debt issues and bonds are public debt issues. In each year, we classify firms into one of four groups based on whether the firm obtained: (i) no debt; (ii) bank debt only; (iii) public debt only; or (iv) both bank and public debt. The proportions of firms in each group at the beginning and end of each two-year period characterize an initial and a final state vector and a Markov transition matrix describes the passage of firms to state $i$ in period $t+l$ from state $j$ in period $t$. The steady state distributions are the long-run equilibriums implied by each set of two-year market dynamics. Panel B report the conditional probabilities of obtaining bank (public) debt conditional on securing public (bank) debt previously. Panel $\mathrm{C}$ shows the average transition matrices for the pre-crisis, crisis, and post-crisis periods. * denotes a value that is significantly different from the average transition matrices between 1989 and 2011 at $10 \%$ or better.

\begin{tabular}{|c|c|c|c|c|c|c|c|}
\hline \multicolumn{8}{|c|}{ Panel A: Steady State Dynamics of Aggregate Debt Financing } \\
\hline & $\begin{array}{l}2004- \\
2005\end{array}$ & $\begin{array}{l}2005- \\
2006\end{array}$ & $\begin{array}{l}\text { 2006- } \\
2007\end{array}$ & $\begin{array}{l}2007- \\
2008\end{array}$ & $\begin{array}{c}2008- \\
2009\end{array}$ & $\begin{array}{c}2009- \\
2010\end{array}$ & $\begin{array}{l}2010- \\
2011\end{array}$ \\
\hline No Debt & 0.420 & 0.438 & 0.457 & $0.578 *$ & 0.554 & 0.464 & $0.373 *$ \\
\hline Loans Only & 0.524 & 0.482 & 0.449 & 0.325 & $0.246 *$ & 0.380 & 0.495 \\
\hline Bonds Only & 0.021 & 0.034 & 0.042 & 0.069 & $0.150 *$ & 0.089 & 0.037 \\
\hline Loans and Bonds & 0.036 & 0.045 & 0.053 & 0.028 & 0.050 & 0.068 & $0.095 *$ \\
\hline \multicolumn{8}{|c|}{ Panel B: Conditional Probabilities of Funding Choice } \\
\hline & $\begin{array}{l}\text { 2004- } \\
2005\end{array}$ & $\begin{array}{l}2005- \\
2006\end{array}$ & $\begin{array}{l}\text { 2006- } \\
2007\end{array}$ & $\begin{array}{l}2007- \\
2008\end{array}$ & $\begin{array}{l}\text { 2008- } \\
2009\end{array}$ & $\begin{array}{l}2009- \\
2010\end{array}$ & $\begin{array}{l}\text { 2010- } \\
2011\end{array}$ \\
\hline Prob.(Bonds | Loans) & 0.064 & 0.086 & 0.106 & 0.080 & 0.169 & 0.152 & 0.160 \\
\hline Prob.(Loans | Bonds) & 0.636 & 0.570 & 0.561 & 0.288 & 0.249 & 0.434 & 0.718 \\
\hline
\end{tabular}


Table 2: Transition Matrices of Debt Funding Outcomes (Cont.)

$$
\text { Panel C: Average Transition Matrices }
$$

Final State

Initial State No Debt Loans Only Bonds Only Loans and Bonds Pre-Crisis Average Transition Matrix (2004-2005, 2005-2006, 2006-2007)

No Debt

0.353

0.542

0.344

0.231

Loans only

0.607

0.403

0.233

0.327

Bonds only

0.019

0.019

0.267

0.138

Loans and Bonds

0.021

0.036

0.156

0.305

Crisis Average Transition Matrix (2007-2008, 2008-2009)

$\begin{array}{lllll}\text { No Debt } & 0.525 & 0.747 & 0.414 & 0.321 \\ \text { Loans only } & 0.380 & 0.194 & 0.073 & 0.139 \\ \text { Bonds only } & 0.070 & 0.031 & 0.430 & 0.312 \\ \text { Loans and Bonds } & 0.025 & 0.027 & 0.083 & 0.227\end{array}$

Post-Crisis Average Transition Matrix (2009-2010, 2010-2011)

\begin{tabular}{lllll} 
No Debt & 0.274 & 0.609 & 0.305 & 0.213 \\
Loans only & 0.614 & 0.322 & 0.263 & 0.314 \\
Bonds only & 0.059 & 0.017 & 0.214 & 0.175 \\
Loans and Bonds & 0.052 & 0.052 & 0.218 & 0.298 \\
\hline
\end{tabular}




\section{Table 3: Attributes of Corporate Borrowers}

Table reports average values on key attributes of the publicly traded firms in our sample. The values are categorized by whether the firm obtained bank or public debt during the year. $Q$ is the ratio of Market Value of Assets to Total Assets. Return on Assets (ROA) is the ratio of Net Income to Total Assets. Total Assets are expressed in billion dollars. MVA is the Market Value of Assets $=$ Total Assets + Outstanding Common Shares at Fiscal Year Closing Share Price - Book Value of Equity - Deferred Taxes. Fixed Assets are Net Property, Plant and Equipment. Financial Debt is the sum of Debt in Current Liabilities and Long Term Debt. Cash are Cash and Short-term investments. Firm $S \& P$ Rating is the annual average of the monthly $S \& P$ domestic long term issuer credit ratings. Age is the difference between a given year and the year in which the firm first appears in the Compustat Fundamentals Annual data set. ***, **, * denote $p$-values equal to or less than $1 \%, 5 \%$, and $10 \%$, respectively, for comparisons across contract types in the same period. ${ }^{\dagger \dagger}, \dagger^{\dagger},{ }^{\dagger}$ denote $p$-values equal to or less than $1 \%, 5 \%$, and $10 \%$, respectively, for comparisons between a given year and the 2006 pre-crisis year.

\begin{tabular}{|c|c|c|c|c|}
\hline & \multicolumn{2}{|c|}{2004} & \multicolumn{2}{|c|}{2005} \\
\hline & Loan & Bond & Loan & Bond \\
\hline Q & $1.89 * *$ & 1.63 & $1.76 *$ & 1.60 \\
\hline ROA & $0.02 * * *$ & 0.05 & $0.03 * * *$ & 0.05 \\
\hline Total Assets (\$B) & $6.33 * * *$ & 17.17 & $8.45 * *$ & $13.55^{\dagger}$ \\
\hline MVA (\$B) & $9.92 * * *$ & 32.64 & $12.50 * *$ & $22.50^{\dagger}$ \\
\hline Fixed Assets/Total Assets & $0.33 * * *$ & 0.50 & $0.33 * * *$ & 0.47 \\
\hline Cash/Total Assets & $0.09 * * *$ & 0.05 & $0.08 * * *$ & 0.04 \\
\hline Financial Debt/Total Assets & 0.33 & 0.35 & 0.32 & 0.31 \\
\hline Firm S\&P Rating & $12.17 * * *$ & 14.73 & $12.15 * * *$ & $15.05^{\dagger \dagger}$ \\
\hline \multirow[t]{3}{*}{ Age } & $22.60 * * *$ & 36.97 & $23.18 * * *$ & 39.37 \\
\hline & \multicolumn{2}{|c|}{2006} & \multicolumn{2}{|c|}{2007} \\
\hline & Loan & Bond & Loan & Bond \\
\hline Q & $1.83 * * *$ & 1.63 & $1.83 * * *$ & 1.63 \\
\hline ROA & $0.03 * * *$ & 0.05 & $0.03 * * *$ & 0.05 \\
\hline Total Assets (\$B) & $8.28 * * *$ & 19.59 & $8.28 * * *$ & 19.59 \\
\hline $\operatorname{MVA}(\$ B)$ & $12.42 * * *$ & 31.66 & $12.42 * * *$ & 31.66 \\
\hline Fixed Assets/Total Assets & $0.33 * * *$ & 0.46 & $0.33 * * *$ & 0.46 \\
\hline Cash/Total Assets & $0.09 * * *$ & 0.04 & $0.09 * * *$ & 0.04 \\
\hline Financial Debt/Total Assets & 0.33 & 0.33 & 0.33 & 0.33 \\
\hline Firm S\&P Rating & $12.02 * * *$ & 14.46 & $12.02 * * *$ & 14.46 \\
\hline Age & $23.51 * * *$ & 37.24 & $23.51 * * *$ & 37.24 \\
\hline
\end{tabular}


Table 3: Attributes of Corporate Borrowers (Cont.)

\begin{tabular}{|c|c|c|c|c|}
\hline \multirow[b]{3}{*}{ Q } & \multicolumn{2}{|c|}{2008} & \multicolumn{2}{|c|}{2009} \\
\hline & Loan & \multirow{2}{*}{$\begin{array}{l}\text { Bond } \\
1.46^{\dagger \dagger}\end{array}$} & Loan & \multirow{2}{*}{$\begin{array}{l}\text { Bond } \\
1.46^{\dagger \dagger}\end{array}$} \\
\hline & 1.38 & & 1.38 & \\
\hline ROA & $-0.09 * * * \dagger$ & 0.05 & $-0.09 * * * \dagger \dagger$ & 0.05 \\
\hline Total Assets (\$B) & $7.13 * * *$ & 22.09 & $7.13 * * *$ & 22.09 \\
\hline MVA $(\$ B)$ & $8.45 * * * \dagger$ & 38.22 & $8.45 * * * \dagger$ & 38.22 \\
\hline Fixed Assets/Total Assets & $0.34 * * *$ & 0.49 & $0.34 * * *$ & 0.49 \\
\hline Cash/Total Assets & $0.10 * * * \dagger$ & 0.05 & $0.10 * * * \dagger$ & 0.05 \\
\hline Financial Debt/Total Assets & $0.30 * \dagger$ & 0.33 & $0.30 * \dagger$ & 0.33 \\
\hline Firm S\&P Rating & $12.31 * * *$ & $15.10^{\dagger \dagger}$ & $12.31 * * *$ & $15.10^{\dagger \dagger}$ \\
\hline \multirow[t]{3}{*}{ Age } & $23.34 * * *$ & $41.87^{\dagger \dagger}$ & $23.34 * * *$ & $41.87^{\dagger \dagger}$ \\
\hline & \multicolumn{2}{|c|}{2010} & \multicolumn{2}{|c|}{2011} \\
\hline & Loan & Bond & Loan & Bond \\
\hline Q & $1.54 * * \dagger \dagger$ & 1.67 & $1.58 \dagger \dagger$ & 1.65 \\
\hline ROA & $0.03 * * *$ & 0.06 & $0.04 * * *$ & 0.06 \\
\hline Total Assets (\$B) & $9.39 * * *$ & 18.67 & $9.78 * * *$ & 22.99 \\
\hline MVA (\$B) & $13.37 * * *$ & 31.19 & $13.07 * * *$ & 39.97 \\
\hline Fixed Assets/Total Assets & $0.35 * * * \dagger$ & 0.42 & $0.35 * * * \dagger \dagger$ & 0.43 \\
\hline Cash/Total Assets & $0.10^{\dagger}$ & $0.09 \dagger$ & 0.09 & $0.088^{\dagger \dagger}$ \\
\hline Financial Debt/Total Assets & 0.31 & 0.33 & 0.31 & 0.32 \\
\hline Firm S\&P Rating & $11.77 * * *$ & $13.84^{\dagger \dagger}$ & $12.17 * * *$ & 14.49 \\
\hline Age & $26.56 * * * \dagger \dagger$ & 36.90 & $28.46 * * * \dagger \dagger$ & 38.64 \\
\hline
\end{tabular}


Table 4: Predicting Debt Contract Type

Contract type is a limited dependent variable which takes a value of 1 if Bank Debt, and 0, if Public Debt. Bank debt are syndicated bank loans and public debt are non-convertible debt issues purchased by non-financial institutions and general investing public. The sample combines syndicated bank loans and public debt issues reported monthly on the DealScan and Thomson Reuters Securities Data Commission (SDC) Platinum databases respectively over the period 20042006 where the borrowing firms can be identified and financial statement data are available. Amount is the size of the debt issue in billions of dollars. Maturity is the contract length at issue in months. All firm characteristics are lagged one period. $Q$ is the ratio of Market Value of Assets $(M V A)$ to Total Assets where MVA = Total Assets + Outstanding Common Shares at Fiscal Year Closing Share Price - Book Value of Equity - Deferred Taxes. ROA is the ratio of Net Income to Total Assets. Fixed Assets are Net Property, Plant and Equipment. Total Assets are in billions of dollars. Financial Debt is the sum of Debt in Current Liabilities and Long Term Debt. Cash are Cash and Short-Term Investments. Bank-Funded and Public-Funded Last 5 Years are dummy variables that take on a value of 1 if the firm obtained bank debt and public debt respectively in the past 5 years and 0 otherwise. Similarly, Revolver Line Last 5 Years is a dummy variable that takes on value 1 if the firm obtained a revolver syndicated loan during the last 2 years and 0 otherwise. Firm $S \& P$ Rating is an integer between 1 and 22 where 1 corresponds to a $\mathrm{D}$ and 22 to an AAA domestic long term issuer credit rating respectively by $S \& P$. ***, **, * denote significance at $1 \%, 5 \%$, and $10 \%$ levels, respectively.

\section{Panel A: Base Model}

Limited Dependent Variable: Bank Debt $=1 /$ Public Debt $=0$

2004-2006

Constant

Amount

Maturity

Q

ROA

Total Assets

Fixed Assets/Total Assets

Cash/Total Assets

Financial Debt/Total Assets

Bank Funded Last 5 Years

Public Funded Last 5 Years

Revolver Line Last 2 Years

Firm S\&P Rating

Observations

Pseudo R-Squared
$9.749 * * *$

$1.403 * * *$

$-0.064 * * *$

0.161

$-1.815$

$0.003 * * *$

$-0.078$

$2.815 * *$

0.522

$1.952 * * *$

$-0.742 * * *$

$-0.337$

$-0.418 * * *$

3,136

0.56
2007

$9.781 * * *$

$0.990 * * *$

$-0.057 * * *$

$0.332 *$

$-4.316 * *$

0.001

$-0.838$

$-1.285$

$1.522 *$

$1.327 * *$

$-0.465 *$

$-0.463$

$-0.432 * * *$

1,035

0.56
2008

$12.073 * * *$

$2.567 * * *$

$-0.081 * * *$

0.362

$-15.278 * * *$

$-0.055 * * *$

0.588

2.384

$-1.949$

1.426

$-1.298 * * *$

$-0.747$

$-0.467 * * *$

560

0.71 
Table 4: Predicting Debt Contract Type (Cont.)

\begin{tabular}{lccc}
\hline & Panel A: Base Model (Cont.) & \\
Limited Dependent Variable: Bank Debt $=1$ / Public Debt $=0$ & $\mathbf{2 0 1 0}$ & $\mathbf{2 0 1 1}$ \\
Constant & $\mathbf{2 0 0 9}$ & $14.355 * * *$ & $9.707 * * *$ \\
Amount & $11.722 * * *$ & $1.639 * * *$ & $1.837 * * *$ \\
Maturity & $0.676 * *$ & $-0.112 * * *$ & $-0.063 * * *$ \\
Q & $-0.117 * * *$ & $-1.291 * * *$ & -0.062 \\
ROA & -0.426 & $2.503 *$ & $-7.590 * * *$ \\
Total Assets & -1.995 & -0.001 & $-0.008 * * *$ \\
Fixed Assets/Total Assets & $0.004 * *$ & -1.014 & 0.593 \\
Cash/Total Assets & 1.119 & -1.584 & 0.676 \\
Financial Debt/Total Assets & 4.477 & 0.948 & 1.006 \\
Bank Funded Last 5 Years & $3.205 * * *$ & $1.965 * * *$ & $2.003 * * *$ \\
Public Funded Last 5 Years & $-0.854 * *$ & $-1.959 * * *$ & $-1.958 * * *$ \\
Revolver Line Last 2 Years & $-0.921 * *$ & 0.355 & -0.166 \\
Firm S\&P Rating & $-0.640 * * *$ & $-0.505 * * *$ & $-0.437 * * *$ \\
Observations & 674 & 775 & 1,118 \\
Pseudo R-Squared & 0.74 & 0.70 & 0.59 \\
\hline
\end{tabular}


Table 4 (Continued): Predicting Debt Contract Type

Panel B are logistic regressions of contract type on firm attributes and contract characteristics taking the supply of bank loans into account. SLOOS C\&I tightening standards, reported quarterly in the Federal Reserve Senior Loan Officer Opinion Survey, reflect lender tightening trends on commercial and industrial loans. All other data are annual. $* * *, * *, *$ denote significance at $1 \%$, $5 \%$, and $10 \%$ levels, respectively.

\section{Panel B: Full Model}

Limited Dependent Variable: Bank Debt $=1 /$ Public Debt $=0$

$\begin{array}{lccc} & \mathbf{2 0 0 4 - 2 0 0 6} & \mathbf{2 0 0 7} & \mathbf{2 0 0 8} \\ \text { Constant } & 9.523 * * * & 9.846 * * * & 15.543 * * * \\ \text { Amount } & 1.419 * * * & 0.993 * * * & 2.786 * * * \\ \text { Maturity } & -0.064 * * * & -0.057 * * * & -0.090 * * * \\ \text { Q } & 0.162 & 0.305 * & 0.396 \\ \text { ROA } & -1.658 & -4.240 * * & -17.131 * * * \\ \text { Total Assets } & 0.003 * * * & 0.001 & -0.059 * * * \\ \text { Fixed Assets/Total Assets } & -0.046 & -0.793 & 0.779 \\ \text { Cash/Total Assets } & 2.908 * * & -1.234 & 2.928 \\ \text { Financial Debt/Total Assets } & 0.470 & 1.515 * * & -2.603 * * \\ \text { Bank Funded Last 5 Years } & 1.936 * * * & 1.329 * * & 0.793 \\ \text { Public Funded Last 5 Years } & -0.751 * * * & -0.460 * & -1.172 * * \\ \text { Revolver Line Last 2 Years } & -0.299 & -0.484 & -0.794 * \\ \text { Firm S\&P Rating } & -0.421 * * * & -0.438 * * * & -0.513 * * * \\ \text { SLOOS C\&I Tightening Standards } & -0.014 & 0.014 & -0.030 * * * \\ \text { Observations } & 3,136 & 1,035 & 560 \\ \text { Pseudo R-Squared } & 0.56 & 0.56 & 0.72\end{array}$


Table 4 (Continued): Predicting Debt Contract Type

Panel B: Full Model (Cont.)

Limited Dependent Variable: Bank Debt $=1$ / Public Debt $=0$

20092010

Constant

Amount

Maturity

Q

ROA

Total Assets

Fixed Assets/Total Assets

Cash/Total Assets

Financial Debt/Total Assets

Bank Funded Last 5 Years

Public Funded Last 5 Years

Revolver Line Last 2 Years

Firm S\&P Rating

SLOOS C\&I Tightening Standards

Observations

Pseudo R-Squared
$11.963 * * *$

$0.663 * *$

$-0.116 * * *$

$-0.425$

$-2.098$

$0.004 * *$

1.152

4.441

1.142

$3.078 * * *$

$-0.832 * *$

$-0.634 * * *$

$-0.006$

674

0.74
$-0.895 * *$
13.730 ***

$1.654 * * *$

$-0.112 * * *$

$-1.283 * * *$

$2.396 *$

$-0.001$

$-1.069$

$-1.803$

1.010

$1.918 * * *$

$-1.969 * * *$

0.344

$-0.513 * * *$

$-0.096$

775

0.71
2011

$9.719 * * *$

$1.837 * * *$

$-0.063 * * *$

$-0.062$

$-7.587 * * *$

$-0.008 * * *$

0.592

0.672

1.006

$2.003 * * *$

$-1.957 * * *$

$-0.166$

$-0.437 * * *$

0.001

1,118

0.59 


\section{Table 5: Excess Probability}

Excess probabilities, expressed in percentages, examine whether firms which successfully obtained bank (public) debt in the crisis year will be more or less successful in obtaining bank (public) debt in the pre-crisis period. The Base Model only accounts for contract characteristics and firm attributes; the Full Model takes the tightening of bank credit conditions into consideration as well. Specifically, we estimate logistic regressions where contract type is the limited dependent variable. A Base (Full) Model is estimated over the pre-crisis period 2004-2006, and similarly, in each year between 2004 and 2011. The results are reported in Table 4. We use the estimated Base (Full) Model associated with the pre-crisis period 2004-2006 and the crisis year to compute the likelihoods that firms which borrowed in the crisis year were also likely to receive bank (public) debt in the pre-crisis year.

\section{Contract Type $=$ Bank Debt}

Mean

\section{Base Model}

2004

2005

2006

2007

2008

2009

2010

2011

Full Model

\begin{tabular}{cc}
2004 & 0.01 \\
2005 & 0.01 \\
2006 & -0.02 \\
2007 & -0.01 \\
2008 & -0.04 \\
2009 & -0.09 \\
2010 & -0.07 \\
2011 & -0.07 \\
\hline
\end{tabular}

$-0.02$

$-0.10$

$-0.07$

\section{Standard Deviation}
0.05
0.05
0.05
0.05
0.14
0.15
0.13
0.12

$t$-statistic
$-15.28$

0.05

0.06

7.46

5.83

0.05

$-11.75$

$-4.59$

0.11

$-5.61$

0.14

$-11.42$

0.12

$-11.99$

0.12 $p$-value

\section{Number of Observations}

931

912

829

786

317

316

457

764

$\begin{array}{ll}0.00 & 317 \\ 0.00 & 316 \\ 0.00 & 457 \\ 0.00 & 764\end{array}$

0.00

931

0.00

912

0.00

829

0.00

786

0.00

317

0.00

316

0.00

457

0.00

764 


\section{Contract Type $=$ Public Debt}

$\begin{array}{llll}\text { Mean } & \begin{array}{l}\text { Standard } \\ \text { Deviation }\end{array} \quad t \text {-statistic } & p \text {-value } & \begin{array}{l}\text { Number of } \\ \text { Observations }\end{array}\end{array}$

\section{Base Model}

$\begin{array}{llllll}2004 & 0.04 & 0.08 & 5.44 & 0.00 & 136 \\ 2005 & 0.02 & 0.10 & 2.42 & 0.02 & 146 \\ 2006 & 0.02 & 0.07 & 2.96 & 0.00 & 186 \\ 2007 & 0.03 & 0.07 & 6.46 & 0.00 & 249 \\ 2008 & 0.28 & 0.28 & 15.76 & 0.00 & 245 \\ 2009 & 0.36 & 0.30 & 22.71 & 0.00 & 359 \\ 2010 & 0.28 & 0.25 & 19.91 & 0.00 & 318 \\ 2011 & 0.19 & 0.19 & 18.81 & 0.00 & 354\end{array}$

Full Model

\begin{tabular}{llllll}
2004 & 0.04 & 0.08 & 6.13 & 0.00 & 136 \\
2005 & 0.03 & 0.11 & 2.99 & 0.00 & 146 \\
2006 & 0.01 & 0.07 & 1.36 & 0.17 & 186 \\
2007 & 0.00 & 0.06 & 1.00 & 0.32 & 249 \\
2008 & 0.19 & 0.24 & 12.60 & 0.00 & 245 \\
2009 & 0.27 & 0.26 & 19.98 & 0.00 & 359 \\
2010 & 0.27 & 0.24 & 19.59 & 0.00 & 318 \\
2011 & 0.18 & 0.18 & 18.71 & 0.00 & 354 \\
\hline
\end{tabular}




\section{Table 6: Impact of Bank Distress on Liquidity, Loan, and Asset Growth}

Table reports OLS coefficient estimates of: (i) lagged bivariate regressions of the quarterly $(t, t+l)$ growth rates in Liquidity, Loans, and Assets on Expected Default at quarter $t$; (ii) contemporaneous bivariate regressions of the quarterly growth rates in Loans and Assets on the quarterly growth rate in Liquidity; and (iii) contemporaneous bivariate regressions of the quarterly growth rate in Assets on the quarterly growth rate in Loans. Growth rates in the regressions are expressed as percentages and include (unreported) constant terms. Financial data on bank holding companies (BHCs) were obtained from FR Y9C quarterly reports corresponding to the period 2004 through 2011. Liquidity is Cash and balances due from depository institutions plus securities, Federal Funds sold, and securities purchased under agreements to resell. Loan is Total Loans. Asset is Total Assets. Growth rates are Winsorized at the 5\% and 95\% levels.

\section{Dependent Variable \\ $\% \Delta$ Liquidity $_{\mathrm{t}, \mathrm{t}+1} \quad \% \Delta$ Loans $_{\mathrm{t}, \mathrm{t}+1} \quad \% \Delta$ Assetss $_{\mathrm{t}, \mathrm{t}+\mathrm{t}}$}

Panel A: 2004 - 2006

$\mathrm{EDF}_{\mathrm{t}}$

$\% \Delta$ Liquidity $_{t, t+1}$

$\% \Delta$ Loans $_{t, t+1}$

No. of Observations

$\mathrm{EDF}_{\mathrm{t}}$

$\% \Delta$ Liquidity $_{\mathrm{t}, \mathrm{t}+1}$

$\% \Delta$ Loanst $t+1+1^{2}$

No. of Observations

$\mathrm{EDF}_{\mathrm{t}}$

$\% \Delta$ Liquidity $_{\mathrm{t}, \mathrm{t}+1}$

$\% \Delta$ Loanst $t+1+1^{2}$

No. of Observations
Coefficient $\quad-0.074$

p-value

Coefficient

p-value

Coefficient

p-value

-0.074
0.011

$-0.021$

0.044

$-0.002$

0.739

$-0.042$

0.000

0.215

0.000

0.661

0.000

4,080

Panel B: 2007 - 2009

$\begin{array}{rccc}\text { Coefficient } & 0.049 & -0.048 & -0.031 \\ \text { p-value } & 0.000 & 0.000 & 0.000 \\ \text { Coefficient } & & -0.018 & 0.156 \\ \text { p-value } & & 0.000 & 0.000 \\ \text { Coefficient } & & & 0.664 \\ \text { p-value } & & & 0.000\end{array}$

3,803

Panel C: 2010 - 2011

$\begin{array}{rccc}\text { Coefficient } & -0.017 & -0.041 & -0.036 \\ \text { p-value } & 0.021 & 0.000 & 0.000 \\ \text { Coefficient } & & -0.025 & 0.188 \\ \text { p-value } & & 0.000 & 0.000 \\ \text { Coefficient } & & & 0.590 \\ \text { p-value } & & & 0.000 \\ & & & 2,473\end{array}$




\section{Table 7: Migration of Corporate Debt Funding Outcomes - Model 1}

Table reports multinomial logit regressions of the debt choices of firms that obtained some or all of its debt through syndicated loans by a single lead bank in a given year $t$ between 2004 and 2010. The dependent variable is an indicator variable which represents one of four possible borrowing outcomes at $t+1$ : no debt, bank debt only, public debt only, both bank and public debt. The debt choice at $t+1$ used as reference is bank debt only. $S \& P$ rated takes a value of 1 if the firm had an $S \& P$ long term debt or subordinated debt rating in period t, and 0 otherwise. $S \& P$ investment grade takes a value of 1 if the firm had an $S \& P$ long-term debt or subordinated debt rating equal to or better than BBB- in period $t$, and 0 otherwise. Firm and bank attributes used as controls are period $t$ and $t+l$ values, respectively. Banking industry EDF is the annual average of the monthly EDF averages across all BHCs where EDFs can be computed. EDF Bracket is the annual average percentile bracket associated with the lead bank's monthly EDF. Higher brackets represent higher EDFs. Estimated coefficients in the years 2008 and 2009 capture the impact of the lead bank distress on the borrowing outcome of firms during the crisis. Banking industry Ratings Change is the average of $S \& P$ Distress across all BHCs with ratings. BHC $S \& P$ distress reflects changes in the condition of the lead bank as the difference between its highest $S \& P$ long term issuer credit rating in $\mathrm{t}$ and its lowest rating in $t+1 . S \& P$ Upgraded (Downgraded) is an indicator variable that takes on value 1 if the average $S \& P$ long term issuer credit rating of the bank in $t+1$ is higher (lower) than that in t, and 0 otherwise. Estimated coefficients capture the average effects and the additional impact of distress (downgrade) in 2008 and 2009. Standard errors are clustered by borrower. $* * *, * *, *$ denote significance at $1 \%, 5 \%$, and $10 \%$ levels, respectively. $\dagger$ Sum of the lead bank average distress coefficient and lead bank marginal distress coefficient in the given year are greater than zero and statistically significant at the $10 \%$ level or better.

\section{Period $\mathbf{t}$ Migration from Bank Debt or Bank and Pubic Debt}

Constant

\section{Borrower Attributes (t) \\ Q}

ROA

Total Assets

Fixed Assets/Total Assets

Cash/Total Assets

Financial Debt/Total Assets

Bank Funded Last 5 Years

Public Funded Last 5 Years

Revolver Line Last 2 Years

S\&P Rated

S\&P Investment Grade

Banking Industry Distress ( $t+1)$

Industry EDF

Lead Bank Distress $(t+1)$

EDF Bracket

EDF Bracket x 2008

EDF Bracket x 2009

Observations

Pseudo R-Squared
Period $\mathbf{t}+1$

No Debt Public Debt

$1.184 * * *$
-0.036
$-0.521 *$
-0.001
$-0.417 * *$
$1.309 * *$
$-0.504 *$
0.021
-0.092
$-0.353 * * *$
$-0.619 * * *$
-0.162

$1.748 * *$

0.000

$0.048^{\dagger * * *}$

0.020

2,376

0.14
Only

\section{Bank \& Public Debt}

$-6.629 * * *$

$\begin{array}{ll}0.118 & 0.156 \\ 2.094 * * * & 1.393 * \\ 0.003 * * * & 0.001 \\ 2.370 * * * & 1.954 * * * \\ 0.284 & -2.854 \\ -2.462 * * & -0.443 \\ -0.805 & -0.763 \\ 1.106 * * * & 1.059 * * * \\ 0.079 * * & 0.364 \\ 1.774 * * & 1.678 * * * \\ 1.627 * * * & 0.705 *\end{array}$

$6.892 * *$

$7.443 * * *$

0.048

$0.029^{\dagger}$

$0.094 * *$

$-0.023^{\dagger}$

$-0.033$

$-0.105$ 
Table 7: Migration of Corporate Debt Funding Outcomes (Cont.) - Model 2

\begin{tabular}{|c|c|c|c|}
\hline $\begin{array}{c}\text { Period t } \\
\text { Migration from Bank Debt or } \\
\text { Bank and Pubic Debt }\end{array}$ & No Debt & $\begin{array}{l}\text { Period t+1 } \\
\text { Public Debt } \\
\text { Only }\end{array}$ & $\begin{array}{c}\text { Bank \& } \\
\text { Public Debt }\end{array}$ \\
\hline Constant & $1.170 * * *$ & $-5.782 * * *$ & $-5.097 * * *$ \\
\hline \multicolumn{4}{|l|}{ Borrower Attributes (t) } \\
\hline Q & -0.035 & 0.111 & 0.167 \\
\hline ROA & $-0.553 * *$ & $2.138 * * *$ & $1.277 *$ \\
\hline Total Assets & -0.001 & $0.003 * * *$ & 0.001 \\
\hline Fixed Assets/Total Assets & $-0.448 * *$ & $2.365 * * *$ & $1.841 * * *$ \\
\hline Cash/Total Assets & $1.356 * * *$ & 0.455 & -3.000 \\
\hline Financial Debt/Total Assets & $-0.476 *$ & $-2.405 * *$ & -0.403 \\
\hline Bank Funded Last 5 Years & -0.030 & -0.859 & -0.842 \\
\hline Public Funded Last 5 Years & -0.080 & $1.075 * * *$ & $0.967 * * *$ \\
\hline Revolver Line Last 2 Years & $-0.346 * * *$ & 0.209 & 0.461 \\
\hline S\&P Rated & $-0.615 * * *$ & $1.832 * *$ & $1.819 * * *$ \\
\hline S\&P Investment Grade & -0.149 & $1.606 * * *$ & $0.669 *$ \\
\hline \multicolumn{4}{|l|}{ Banking Industry Distress $(\mathbf{t}+\mathbf{1})$} \\
\hline Industry Ratings Change & $0.455 * * *$ & 0.729 & $1.074 * *$ \\
\hline \multicolumn{4}{|l|}{ Lead Bank Distress $(t+1)$} \\
\hline Ratings Upgrade & 0.146 & -0.144 & -0.212 \\
\hline Ratings Downgrade & -0.051 & -0.017 & -0.737 \\
\hline Ratings Downgrade x 2008 & $0.848^{\dagger} * * *$ & $0.754^{\dagger}$ & 0.270 \\
\hline Ratings Downgrade x 2009 & 0.062 & 0.578 & -0.213 \\
\hline Observations & 2,423 & & \\
\hline Pseudo R-Squared & 0.13 & & \\
\hline
\end{tabular}


Table 7 (Continued): Migration of Debt Funding Outcomes (Cont.) - Model 3

Table reports a multinomial logit regression of the debt outcomes of firms that obtained some or all its debt through syndicated loans by a single lead bank in a given year $t$ between 2004 and 2010. The dependent variable is an indicator variable which represents one of four possible borrowing outcomes at $t+1$ : no debt, bank debt only, public debt only, both bank and public debt. The debt choice at $t+1$ used as reference is bank debt only. Firm and bank characteristics used as controls are period $t$ and $t+l$ values respectively. Bank liquidity is cash and balances due from depository institutions plus securities plus Federal funds sold and securities purchased under agreements to resell. Bank liquidity hoarding is represented by idiosyncratic residuals on cross-sectional regressions of liquidity growth on asset growth across banks estimated each quarter; residuals are averaged over four quarters to annualize the measure. Coefficients estimated on interacted year 2008 and 2009 dummies capture the impact of lead bank liquidity during the crisis. Standard errors are clustered by borrower. $* * *, * *, *$ denote significance at $1 \%, 5 \%$, and $10 \%$ levels, respectively. 'Sum of the average lead bank and marginal lead bank distress coefficients or average lead bank liquidity and marginal lead bank liquidity coefficients in the given year are statistically significant at the $10 \%$ level or better.

\begin{tabular}{|c|c|c|c|}
\hline $\begin{array}{c}\text { Period t } \\
\text { Migration from Bank Debt or } \\
\text { Bank and Pubic Debt }\end{array}$ & No Debt & $\begin{array}{l}\text { Period t+1 } \\
\text { Public Debt } \\
\text { Only }\end{array}$ & $\begin{array}{c}\text { Bank \& Public } \\
\text { Debt }\end{array}$ \\
\hline Constant & $1.205 * * *$ & $-6.022 * * *$ & $-5.330 * * *$ \\
\hline \multicolumn{4}{|l|}{ Borrower Attributes (t) } \\
\hline Q & -0.021 & 0.121 & 0.125 \\
\hline ROA & $-0.665 * *$ & $2.145 * * *$ & $1.424 *$ \\
\hline Total Assets & -0.001 & $0.003 * * *$ & 0.001 \\
\hline Fixed Assets/Total Assets & $-0.477 * *$ & $2.339 * * *$ & $1.976^{* * *}$ \\
\hline Cash/Total Assets & $1.254 * * *$ & 0.276 & -2.712 \\
\hline Financial Debt/Total Assets & $-0.455 *$ & $-2.409 * *$ & -0.336 \\
\hline Bank Funded Last 5 Years & -0.067 & -0.926 & -0.694 \\
\hline Public Funded Last 5 Years & -0.069 & $1.111 * * *$ & $1.039 * * *$ \\
\hline Revolver Line Last 2 Years & $-0.329 * * *$ & 0.180 & 0.272 \\
\hline S\&P Rated & $-0.575 * * *$ & $1.964 * *$ & $1.841 * * *$ \\
\hline S\&P Investment Grade & -0.160 & $1.618 * * *$ & $0.733 * *$ \\
\hline \multicolumn{4}{|l|}{ Banking Industry Distress $(t+1)$} \\
\hline Industry EDF $(\mathrm{t}+1)$ & $2.575 * * *$ & $5.749 * * *$ & $3.595 * * *$ \\
\hline \multicolumn{4}{|l|}{ Liquidity Hoarding $(\mathbf{t}+\mathbf{1})$} \\
\hline Bank Liquidity Hoarding & -0.164 & 1.113 & -0.273 \\
\hline Bank Liquidity Hoarding x 2008 & $2.114^{\dagger * *}$ & -0.401 & 0.965 \\
\hline Bank Liquidity Hoarding x 2009 & 0.037 & $1.455^{\dagger}$ & 0.639 \\
\hline Observations & 2,599 & & \\
\hline Pseudo R-Squared & 0.13 & & \\
\hline
\end{tabular}


Table 7 (Continued): Migration of Debt Funding Outcomes (Cont.) - Model 4

\begin{tabular}{|c|c|c|c|}
\hline & \multicolumn{3}{|c|}{ Model 4} \\
\hline $\begin{array}{c}\text { Period t } \\
\text { Migration from Bank Debt or } \\
\text { Bank and Pubic Debt }\end{array}$ & No Debt & $\begin{array}{l}\text { Period t+1 } \\
\text { Public Debt } \\
\quad \text { Only }\end{array}$ & $\begin{array}{c}\text { Bank \& Public } \\
\text { Debt }\end{array}$ \\
\hline Constant & $1.229 * * *$ & $-5.990 * * *$ & $-5.349 * * *$ \\
\hline Borrower Attributes (t) & & & \\
\hline Q & -0.020 & 0.136 & 0.142 \\
\hline ROA & $-0.657 * *$ & $2.081 * * *$ & $1.389^{*}$ \\
\hline Total Assets & -0.001 & $0.002 * * *$ & 0.001 \\
\hline Fixed Assets/Total Assets & $-0.470 * *$ & $2.326 * * *$ & $1.957 * * *$ \\
\hline Cash/Total Assets & $1.226^{* *}$ & 0.002 & -2.890 \\
\hline Financial Debt/Total Assets & $-0.460 *$ & $-2.410 * *$ & -0.385 \\
\hline Bank Funded Last 5 Years & -0.075 & -0.964 & -0.736 \\
\hline Public Funded Last 5 Years & -0.081 & $1.096^{* * *}$ & $1.035^{* * *}$ \\
\hline Revolver Line Last 2 Years & $-0.321 * * *$ & 0.240 & 0.310 \\
\hline S\&P Rated & $-0.570 * * *$ & $1.963^{* *}$ & $1.857 * * *$ \\
\hline S\&P Investment Grade & -0.165 & $1.619 * * *$ & $0.733 * *$ \\
\hline Banking Industry Distress $(t+1)$ & & & \\
\hline Industry S\&P Distress $(t+1)$ & $0.418^{* * *}$ & $0.999 * * *$ & $0.696^{* * *}$ \\
\hline Liquidity Hoarding $(\mathbf{t}+\mathbf{1})$ & & & \\
\hline Bank Liquidity Hoarding & -0.174 & 1.182 & -0.180 \\
\hline Bank Liquidity Hoarding x 2008 & $2.792^{\dagger * * *}$ & 1.067 & 1.803 \\
\hline Bank Liquidity Hoarding x 2009 & 0.182 & $1.697^{\dagger}$ & 0.588 \\
\hline Observations & 2,599 & & \\
\hline Pseudo R-Squared & 0.13 & & \\
\hline
\end{tabular}


Table 8: Lead Bank Distress and Corporate Investment

Table reports the impact of lead bank distress in the crisis on capital expenditures (investment) of firms that did not borrow in year $t+l$ but obtained some or all of its debt through syndicated loans in the prior year $t$ scaled by total assets. For example, 2008 to 2009 represent the investment in 2009 of firms that did not borrow in 2009 but borrowed in 2008. Columns labeled $S \& P$ Distressed Lead Bank report investment of firms that borrowed in year $t$ through a lead bank whose $S \& P$ long term domestic issuer credit rating was downgraded more than the median downgrade (of 1 notch) for BHCs during the crisis. Columns labeled Non-Distressed Lead Bank report investment of firms that borrowed in year $t$ through a lead bank whose rating change was less than or equal to the median change. Summary statistics on investment are Winsorized at 5\% and 95\% each year.

Investment in Year $t+1$ for Firms that Migrated from Bank Debt in $t$ to No Debt in $t+1$ Conditioned on the Distress of the Lead Bank

\section{$S \& P$ Non-Distressed $\quad S \& P$ Distressed Lead \\ Lead Bank \\ Bank}

\begin{tabular}{lccccccccc}
$\boldsymbol{t}$ to $\boldsymbol{t}+\boldsymbol{1}$ & Mean & S.D. & Obs. & Mean & S.D. & Obs. & Diff. & t-stat & $\boldsymbol{p}$-val \\
2004 to 2005 & 0.058 & 0.068 & 221 & 0.064 & 0.066 & 212 & -0.007 & -1.037 & 0.300 \\
2005 to 2006 & 0.076 & 0.090 & 199 & 0.065 & 0.069 & 203 & 0.011 & 1.338 & 0.182 \\
2006 to 2007 & 0.074 & 0.085 & 182 & 0.070 & 0.076 & 168 & 0.004 & 0.446 & 0.656 \\
2007 to 2008 & 0.069 & 0.080 & 165 & 0.062 & 0.067 & 207 & 0.007 & 0.937 & 0.349 \\
2008 to 2009 & 0.051 & 0.049 & 128 & 0.042 & 0.039 & 157 & 0.009 & 1.599 & 0.111 \\
2009 to 2010 & 0.036 & 0.049 & 58 & 0.048 & 0.056 & 102 & -0.012 & -1.370 & 0.173 \\
2010 to 2011 & 0.055 & 0.057 & 76 & 0.073 & 0.079 & 94 & -0.017 & -1.675 & 0.096 \\
\hline
\end{tabular}




\section{Table 9: Debt Funding Outcome and Corporate Investment}

This table examines the impact of corporate debt choice on corporate investment decisions taking into account the distress of lead banks, particularly in the crisis years 2008 and 2009. Investment is capital expenditures expressed as percentages of 1-year lagged total assets. Panel regressions control for firm attributes and year fixed effects. Sample are firms, which in a given year $t$ between 2004 and 2010, obtained some or all of its debt through syndicated loans by a single lead bank. The reference group are firms, which migrated from acquiring all or some of its debt through syndicated bank loans in $t$, to bank debt only in $t+1$. Indicator variables Migrated to No Debt, Public Debt, and Bank \& Public Debt account for the three remaining mutually exclusive debt outcomes. Other explanatory variables are previously defined. $S \& P$ Domestic LT Issuer Rating are the ratings of firms at December year-end. Standard errors are clustered by year. ***,**, * denote significance at 1\%,5\%, and $10 \%$ levels, respectively. ${ }^{\dagger}$ Sum of the average lead bank and marginal lead bank distress coefficients in the given year are less than zero and statistically significant at the $10 \%$ level or better. 
Table 9: Debt Funding Outcome and Corporate Investment (Cont.)

\begin{tabular}{|c|c|c|c|}
\hline & Model 1 & Model 2 & Model 3 \\
\hline Constant & $1.666^{*}$ & 1.214 & 1.297 \\
\hline \multicolumn{4}{|l|}{ Borrower Attributes (t) } \\
\hline Q & $1.009 * * *$ & $1.003 * * *$ & $1.033 * * *$ \\
\hline ROA & 0.059 & 0.088 & -0.094 \\
\hline Total Assets & 0.003 & 0.003 & 0.002 \\
\hline Fixed Assets/Total Assets & $21.496 * * *$ & $21.522 * * *$ & $21.716 * * *$ \\
\hline Cash/Total Assets & $3.422 *$ & $3.260 *$ & $3.633 * *$ \\
\hline Financial Debt/Total Assets & $-4.822 * * *$ & $-4.664 * * *$ & $-4.752 * * *$ \\
\hline Bank Funded Last 5 Years & -0.652 & -0.533 & -0.709 \\
\hline Public Funded Last 5 Years & -0.421 & -0.383 & -0.473 \\
\hline Revolver Line Last 2 Years & $0.545 * * *$ & $0.437 * * *$ & $0.435 * * *$ \\
\hline Age & $-0.066 * * *$ & $-0.064 * * *$ & $-0.064 * * *$ \\
\hline S\&P Rated & 0.291 & 0.198 & 0.300 \\
\hline S\&P Investment Grade & $-1.554 * * *$ & $-1.428 * *$ & $-1.555^{* *}$ \\
\hline \multicolumn{4}{|l|}{ Migrated from Bank Debt in $t$} \\
\hline No Debt in $\mathrm{t}+1$ & $-1.014 * * *$ & $-1.050 * * *$ & $-0.934 * * *$ \\
\hline \multirow{3}{*}{$\begin{array}{l}\text { to: Public Debt in } \mathrm{t}+1 \\
\text { Bank \& Public Debt in } \mathrm{t}+1 \\
\text { Lead Bank Distress and Liauid }\end{array}$} & 0.422 & 0.415 & 0.395 \\
\hline & $3.331 * * *$ & $3.127 * * *$ & $3.246 * * *$ \\
\hline & \multicolumn{3}{|c|}{ Lead Bank Distress and Liquidity Hoarding $(t+1)$} \\
\hline EDF Bracket & -0.011 & & \\
\hline EDF Bracket x 2008 & 0.088 & & \\
\hline EDF Bracket x 2009 & $-0.112^{\dagger * *}$ & & \\
\hline Ratings Upgrade & & $0.640 * *$ & \\
\hline Ratings Downgrade & & 0.221 & \\
\hline Ratings Downgrade x 2008 & & $-1.226^{\dagger *}$ & \\
\hline Ratings Downgrade x 2009 & & $-1.831^{\dagger * *}$ & \\
\hline Bank Liquidity Hoarding & & & $2.592 * *$ \\
\hline Bank Liquidity Hoarding x 2008 & & & 0.072 \\
\hline Bank Liquidity Hoarding x 2009 & & & $-2.145^{* *}$ \\
\hline Year Fixed Effects & Yes & Yes & Yes \\
\hline Observations & 2,371 & 2,418 & 2,593 \\
\hline Pseudo R-Squared & 0.52 & 0.52 & 0.52 \\
\hline
\end{tabular}


Table 9: Debt Funding Outcome and Corporate Investment (Cont.)

\begin{tabular}{|c|c|c|c|}
\hline & Model 4 & Model 5 & Model 6 \\
\hline Constant & $1.623^{*}$ & 1.226 & 1.312 \\
\hline \multicolumn{4}{|l|}{ Borrower Attributes (t) } \\
\hline $\mathrm{Q}$ & $1.010 * * *$ & $1.002 * * *$ & $1.036 * * *$ \\
\hline $\mathrm{ROA}$ & 0.064 & 0.056 & -0.091 \\
\hline Total Assets & 0.003 & 0.003 & 0.002 \\
\hline Fixed Assets/Total Assets & $21.484 * * *$ & $21.534 * * *$ & $21.729 * * *$ \\
\hline Cash/Total Assets & $3.427^{*}$ & $3.289 *$ & $3.557 * *$ \\
\hline Financial Debt/Total Assets & $-4.777 * * *$ & $-4.644 * * *$ & $-4.793 * * *$ \\
\hline Bank Funded Last 5 Years & -0.644 & -0.549 & -0.715 \\
\hline Public Funded Last 5 Years & -0.418 & -0.393 & -0.477 \\
\hline Revolver Line Last 2 Years & $0.533 * * *$ & $0.452 * * *$ & $0.438 * * *$ \\
\hline Age & $-0.066 * * *$ & $-0.065 * * *$ & $-0.064 * * *$ \\
\hline S\&P Rated & 0.281 & 0.175 & 0.313 \\
\hline S\&P Investment Grade & $-1.544 * * *$ & $-1.401 * *$ & $-1.555^{* *}$ \\
\hline \multicolumn{4}{|l|}{ Migrated from Bank Debt in $t$} \\
\hline No Debt in $t+1$ & $-1.008 * * *$ & $-1.038 * * *$ & $-0.934 * * *$ \\
\hline \multirow{3}{*}{\multicolumn{4}{|c|}{$\begin{array}{l}\text { to: Public Debt in } \mathrm{t}+1 \\
\text { Bank \& Public Debt in } \mathrm{t}+1 \\
\text { Lead Bank Distress and Liquidity Hoarding }(\mathbf{t}+\mathbf{1})\end{array}$}} \\
\hline & & & \\
\hline & & & \\
\hline EDF Bracket & \multicolumn{3}{|l|}{-0.008} \\
\hline Ratings Upgrade & \multicolumn{3}{|c|}{$0.630 * *$} \\
\hline Ratings Downgrade & \multicolumn{3}{|c|}{$-0.582 *$} \\
\hline Bank Liquidity Hoarding & & & $2.399 * *$ \\
\hline Year Fixed Effects & Yes & Yes & Yes \\
\hline Observations & 2,371 & 2,418 & 2,593 \\
\hline Pseudo R-Squared & 0.52 & 0.52 & 0.52 \\
\hline
\end{tabular}




\section{Table 10: Credit Spreads and Debt Funding Choice}

Table reports cross-sectional regressions of credit spreads against issue characteristics taking differences across firms and industries into account. The costs of syndicated bank and public debt, expressed in basis points, are the spreads over Treasuries with the same maturity. Amount is the size of the syndicated bank or public debt issue in billions of dollars. Maturity is the tenor of the syndicated bank or public debt in months. Bank debt is a dummy variable, which takes a value of 1 if syndicated bank loan, and 0, if public debt. Firm attributes are defined in Table 4 and lagged by a year. All cross-sectional regressions control for industry fixed effects using the Fama and French 17-industry classification. Standard errors are clustered by industry in the year by year regressions, and clustered by year in the regression for all years. $* * *, * * * *$ stand for significance at 1,5 , and $10 \%$ level, respectively.

\begin{tabular}{lcccc}
\hline & $\mathbf{2 0 0 4}$ & $\mathbf{2 0 0 5}$ & $\mathbf{2 0 0 6}$ & $\mathbf{2 0 0 7}$ \\
Constant & $391.50 * * *$ & $431.56 * * *$ & $423.75 * * *$ & $376.89 * * *$ \\
Bank Debt & 13.60 & 10.88 & -5.32 & -3.70 \\
Amount & -7.91 & -3.23 & $-4.06 * * *$ & 2.36 \\
Maturity & 0.05 & 0.04 & $0.09 *$ & $0.13 * *$ \\
Borrower Attributes & & & & \\
Q & -2.94 & -5.30 & -3.09 & 2.02 \\
ROA & $-335.34 * * *$ & $-204.24 * * *$ & $-203.88 * *$ & $-274.32 * *$ \\
Total Assets & 0.07 & $0.22 * *$ & $0.13 *$ & $0.09 * * *$ \\
Fixed Assets/Total Assets & -3.35 & -2.08 & 5.23 & $-45.63 * *$ \\
Cash/Total Assets & 121.59 & 122.37 & 60.19 & 10.08 \\
Financial Debt/Total Assets & $107.53 * * *$ & 32.07 & 79.13 & 18.95 \\
Bank Funded Last 5 Years & 10.41 & -21.00 & -23.13 & 19.49 \\
Public Funded Last 5 Years & -4.61 & -0.24 & -2.65 & -7.87 \\
Firm S\&P Rating & $-20.99 * * *$ & $-20.05 * * *$ & $-19.23 * * *$ & $-15.37 * * *$ \\
2005 & & & & \\
2006 & & & & \\
2007 & & & & \\
2008 & & & & \\
2009 & & & & \\
2010 & & & & \\
2011 & 1,005 & 970 & & \\
Observations & 0.56 & 0.46 & 0.50 & 0.41 \\
Adjusted R-Squared & & & & \\
\hline
\end{tabular}


Table 10: Credit Spreads and Debt Funding Choice (Cont.)

\begin{tabular}{|c|c|c|c|c|c|}
\hline & 2008 & 2009 & 2010 & 2011 & All Years \\
\hline Constant & 651.60 & 744.32 & 539.81 & 499.45 & 460.67 \\
\hline Bank Debt & -137.35 & $-66.72 *$ & 9.31 & -16.43 & -20.04 \\
\hline Amount & -2.77 & 3.67 & -8.67 & -0.08 & -1.62 \\
\hline Maturity & $-0.29 *$ & $-0.26 *$ & -0.03 & 0.09 & -0.03 \\
\hline \multicolumn{6}{|l|}{ Borrower Attributes } \\
\hline Q & -14.11 & $-80.67 * * *$ & $-17.94 * * *$ & -6.26 & $-9.07 *$ \\
\hline ROA & -122.46 & -165.40 & -54.98 & $-195.24 * *$ & -205.42 \\
\hline Total Assets & -0.07 & -0.25 & $0.21 * *$ & 0.04 & $0.11 * *$ \\
\hline Fixed Assets/Total Assets & 1.07 & -56.44 & $-36.00 * *$ & -8.67 & -11.33 \\
\hline Cash/Total Assets & 181.06 & 220.21 & 5.17 & $143.39 *$ & $76.52 * *$ \\
\hline Financial Debt/Total Assets & 102.64 & 124.01 & $69.73 * * *$ & $44.42 *$ & 67.01 \\
\hline Bank Funded Last 5 Years & 25.71 & -34.04 & $30.53 * *$ & 7.85 & -1.42 \\
\hline Public Funded Last 5 Years & 1.01 & 6.21 & -3.03 & 19.34 & 0.18 \\
\hline Firm S\&P Rating & $-24.03 * * *$ & $-20.44 * * *$ & $-25.66 * * *$ & $-25.89 * * *$ & $-21.25 * * *$ \\
\hline 2005 & & & & & $-13.13 * * *$ \\
\hline 2006 & & & & & $-7.37 * * *$ \\
\hline 2007 & & & & & $8.79 * * *$ \\
\hline 2008 & & & & & 132.05 \\
\hline 2009 & & & & & 195.42 \\
\hline 2010 & & & & & $64.11 * * *$ \\
\hline 2011 & & & & & $29.64 * * *$ \\
\hline Observations & 511 & 606 & 708 & 987 & 6,682 \\
\hline Adjusted R-Squared & 0.22 & 0.33 & 0.61 & 0.52 & 0.50 \\
\hline
\end{tabular}




\section{Table 11: Bank Distress and Syndicated Loan Yield Spreads}

Two lead bank distress variables are used. $E D F$ is the expected default frequency of the lead bank three months prior to the syndication of the bank loan. Rating Change is the difference between the lead bank's $S \& P$ Domestic Long Term Issuer Credit Rating fifteen and three months prior to the syndication of the bank loan. Ratings changes are positive (negative) when the lead bank was downgraded (upgraded), and 0 when the rating of the lead bank remained unchanged. Bank liquidity is cash and balances due from depository institutions plus securities plus Federal funds sold and securities purchased under agreements to resell. Bank liquidity hoarding is represented by idiosyncratic residuals on cross-sectional regressions of liquidity growth on asset growth across banks estimated each quarter. Standard errors are clustered by industry. ***, **, * stand for significance at 1,5 , and $10 \%$ level, respectively.

\begin{tabular}{lcccc}
\hline & \multicolumn{3}{c}{ Lead Bank Distress } \\
& $\mathbf{2 0 0 4 - 2 0 0 6}$ & $\mathbf{2 0 0 8 - 2 0 0 9}$ & $\mathbf{2 0 0 4 - 2 0 0 6}$ & $\mathbf{2 0 0 8 - 2 0 0 9}$ \\
Constant & $434.74 * * *$ & $600.51^{* * *}$ & $438.27 * * *$ & $400.97 * * *$ \\
Amount & $-23.26 * *$ & $-56.62^{*}$ & -5.59 & $-53.38^{* *}$ \\
Maturity & 0.21 & -0.32 & 0.07 & -0.11 \\
Borrower Attributes & & & & \\
Q & -0.78 & -27.00 & 1.22 & -16.13 \\
ROA & $-353.73^{* * *}$ & -190.28 & $-374.15^{* *}$ & $-248.88^{*}$ \\
Total Assets & $0.10^{*}$ & -0.08 & 0.04 & -0.05 \\
Fixed Assets/Total Assets & -26.05 & 29.98 & -14.89 & 36.70 \\
Cash/Total Assets & 43.32 & 161.35 & 46.21 & 309.69 \\
Financial Debt/Total Assets & $67.53 * *$ & $133.84 * * *$ & $54.41 * *$ & $113.96 * *$ \\
Bank Funded Last 5 Years & -18.13 & -11.79 & -18.46 & 0.16 \\
Public Funded Last 5 Years & -4.99 & 28.97 & -5.15 & 54.10 \\
Firm S\&P Rating & $-19.07 * * *$ & $-15.78 * * *$ & $-20.14 * * *$ & $-15.16^{* * *}$ \\
Lead Bank Distress and Liquidity Hoarding & & & \\
EDF & -365.08 & $160.09 * *$ & & \\
Ratings Change & & & -1.282 & $32.463 * *$ \\
Observations & 674 & 167 & 750 & 168 \\
Adjusted R-Squared & 0.47 & 0.42 & 0.45 & 0.40 \\
\hline
\end{tabular}


Lead Bank Liquidity 2004-2006 2008-2009

Constant

$436.14 * * * \quad 544.67 * * *$

Amount

$-5.18 \quad-54.96 * *$

Maturity

$0.05 \quad-0.12$

\section{Borrower Attributes}

Q

ROA

Total Assets

Fixed Assets/Total Assets

Cash/Total Assets

Financial Debt/Total Assets

Bank Funded Last 5 Years

$0.98 \quad-32.56$

$-369.29 * *-311.89 * *$

$0.05 \quad 0.04$

$-12.02 \quad 71.71$

$57.28 \quad 323.71$

$57.52 * * \quad 127.78 * * *$

Public Funded Last 5 Years

$-17.47 \quad-49.17$

$-7.53 \quad 46.23$

Firm S\&P Rating

$-20.14 * * * \quad-15.66 * * *$

Lead Bank Distress and Liquidity Hoarding

Liquidity Hoarding

$51.28 * \quad 181.02 *$

Observations

779

171

Adjusted R-Squared

0.46

0.40 


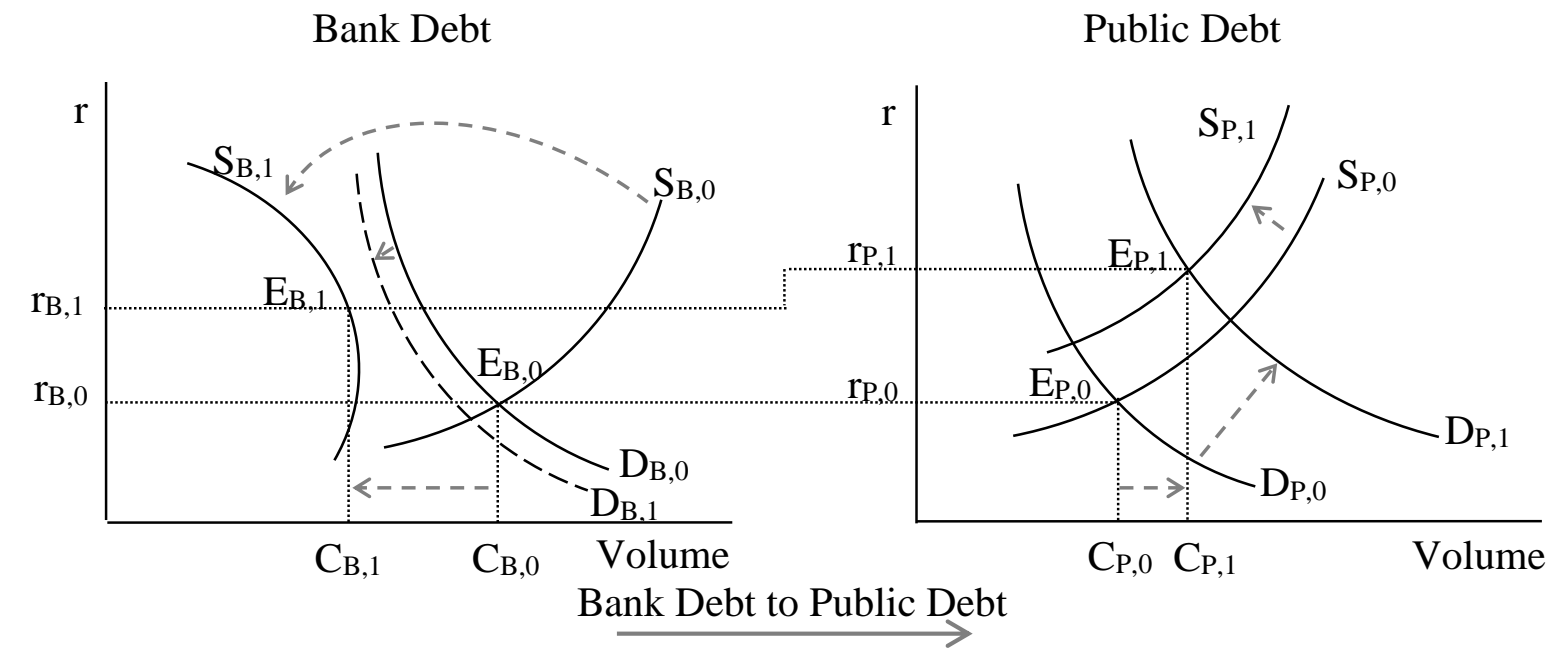

Figure 1: Migration from bank to public debt credit during crisis. The initial equilibriums in bank and public debt markets occur at $\mathrm{E}_{\mathrm{B}, 0}$ and $\mathrm{E}_{\mathrm{P}, 0}$, respectively, where credit is competitively priced. The uncertainty triggered by a crisis decreases the willingness of all lenders to extend credit as a result of higher perceived credit, liquidity, and solvency risks. The supply of credit provided by institutional and retail investors shifts left from $S_{\mathrm{P}, 0}$ to $S_{\mathrm{P}, 1}$. Banks simultaneously curtail lending even to well qualified borrowers, shifting supply from $S_{B, 0}$ to $S_{B, 1}$. In addition, banks choose to ration credit rather than lend at higher rates of interest. Reflecting a weaker economy, the demand for bank debt shifts left from $\mathrm{D}_{\mathrm{B}, 0}$ to $\mathrm{D}_{\mathrm{B}, 1}$. The price of bank debt does not clear - the supply of credit at $\mathrm{C}_{\mathrm{B}, 1}$ is less than the demand for credit at a higher interest rate, $\mathrm{r}_{\mathrm{B}, 1}$. Given the contraction in bank lending, otherwise well qualified borrowers migrate to the public debt market, shifting demand from $\mathrm{D}_{\mathrm{P}, 0}$ to $\mathrm{D}_{\mathrm{P}, 1}$. The public debt market clears at a higher volume, $\mathrm{C}_{\mathrm{P}, 1}>\mathrm{C}_{\mathrm{P}, 0}$, but also at a higher rate of interest than on bank debt, $\mathrm{r}_{\mathrm{P}, 1}>\mathrm{r}_{\mathrm{B}, 1}$. Because the migration from bank to public debt is incomplete, the total volume of credit in the economy falls, $\mathrm{C}_{\mathrm{B}, 1}+\mathrm{C}_{\mathrm{P}, 1}$ $<\mathrm{C}_{\mathrm{B}, 0}+\mathrm{C}_{\mathrm{P}, 0}$. Crisis induced outcomes in bank and public debt are denoted by $\mathrm{E}_{\mathrm{B}, 1}$ and $\mathrm{E}_{\mathrm{P}, 1}$ respectively. 


$$
\varepsilon_{i, t}=\gamma+\phi E D F_{i, t-3}+v_{i, t}
$$

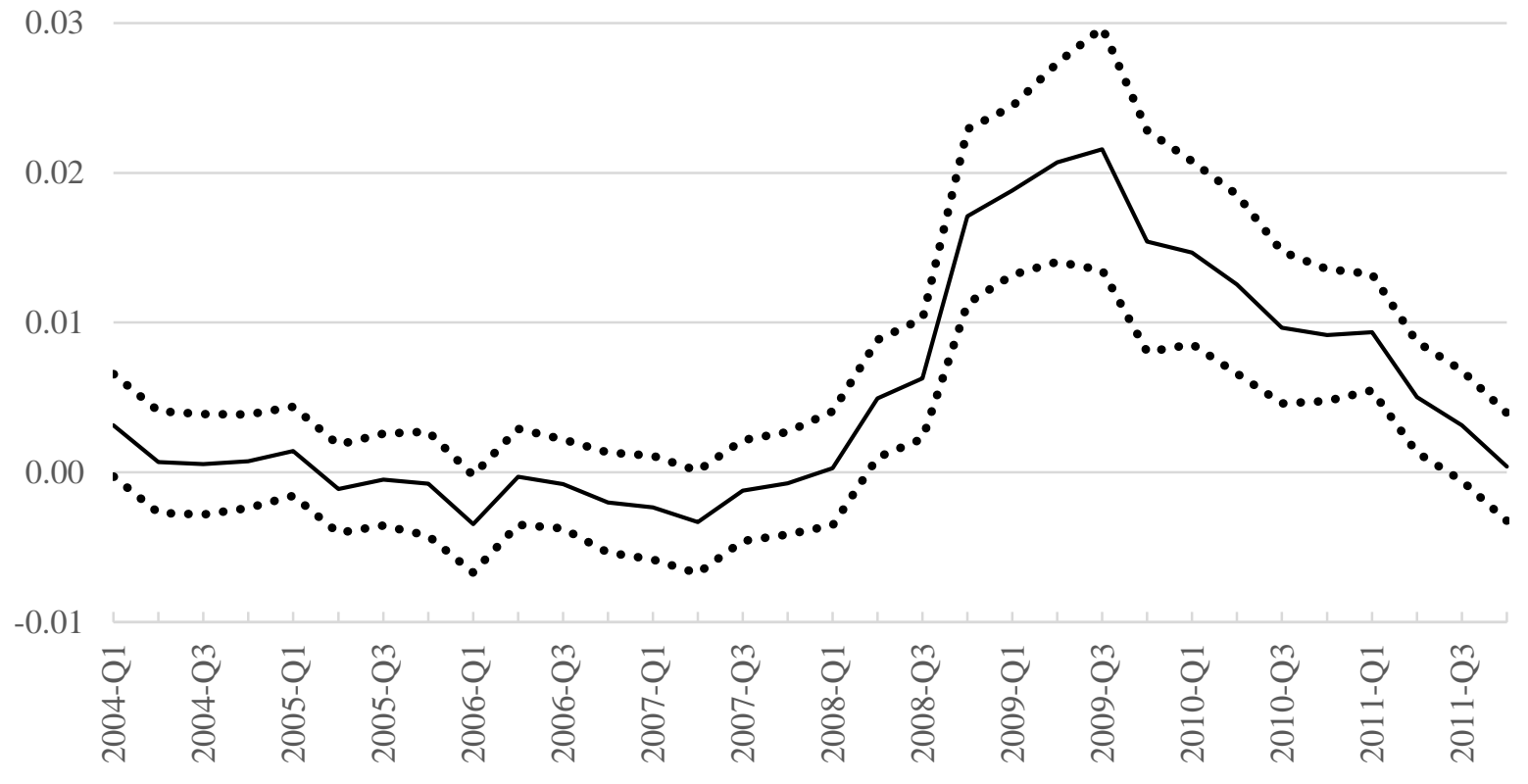

Figure 2. Bank Distress and Liquidity Hoarding. This figure plots the quarterly estimates of $\phi$, the cross-sectional marginal effect of bank EDF bracket at month $t$-3 on liquidity hoarding at

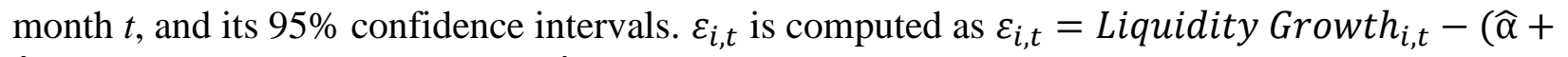
$\hat{\beta}$ Asset Growt $_{i, t}$ ), where $\hat{\alpha}$ and $\hat{\beta}$ are also quarterly cross-sectional estimates. 


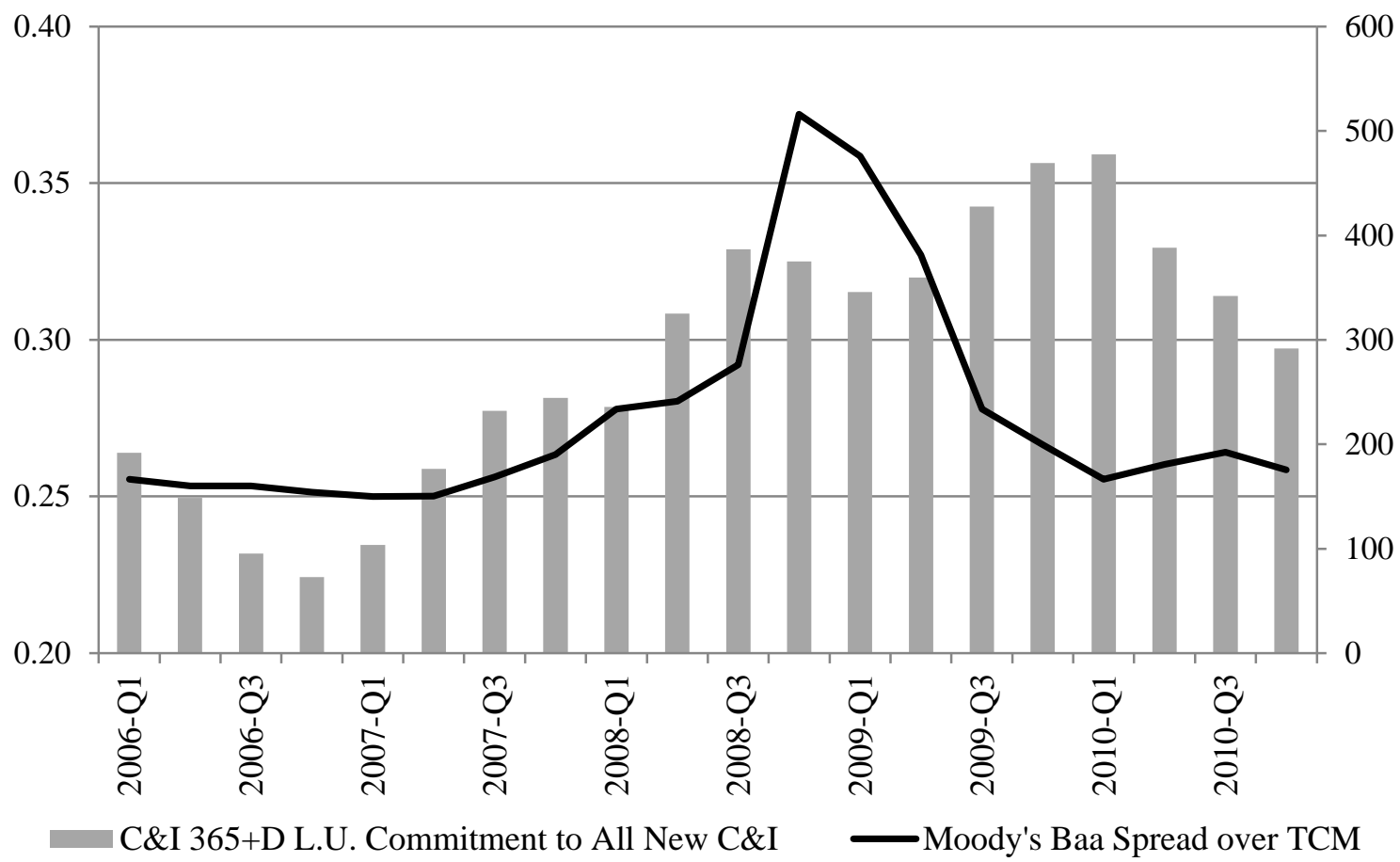

Figure 3. Commitment Drawdowns and Moody's Baa Spread. This figure plots the quarterly loan commitment drawdown ratio between 2006 and 2010 computed as all commercial and industrial (C\&I) loans originated by domestic banks under commitment where the loan terms and pricing were set more than 365 days in the past, divided by all C\&I loans originated by domestic banks. The data are smoothed by averaging values from $t-1, t$, and $t+1$. In addition, we plot the Moody's Baa spread over Treasuries. An increase in the loan commitment ratio is consistent with credit rationing - demand for bank credit expands faster than new credit originations when bond spreads are rising.

Source: Federal Reserve Board of Governors Survey of Terms of Business Lending - E.2. 


\section{APPENDIX I}

Table A.1: Randomly Generated Excess Probability

The excess probabilities reported in this table are computed based on a bootstrap procedure where firm-contracts are randomly assigned to each year. The table are the results from 100 trials. Mean and Standard Error refer to the average of the mean excess probabilities each year across trials and the standard error of the average estimates, respectively.

\begin{tabular}{|c|c|c|c|c|c|c|c|c|c|c|}
\hline & \multicolumn{5}{|c|}{ Contract Type $=$ Bank Debt } & \multicolumn{5}{|c|}{ Contract Type $=$ Public Debt } \\
\hline & Mean & S.E. & Trials & $t$-stat & $p$-val & Mean & S.E. & Trials & $t$-stat & $p$-val \\
\hline \multicolumn{11}{|c|}{ Base Model } \\
\hline 2004 & 0.00 & 0.01 & 100 & 0.21 & 0.83 & 0.01 & 0.02 & 100 & 0.38 & 0.70 \\
\hline 2005 & 0.00 & 0.01 & 100 & 0.11 & 0.91 & 0.01 & 0.02 & 100 & 0.55 & 0.58 \\
\hline 2006 & 0.00 & 0.01 & 100 & 0.27 & 0.79 & 0.01 & 0.02 & 100 & 0.33 & 0.74 \\
\hline 2007 & 0.01 & 0.01 & 100 & 0.39 & 0.70 & 0.01 & 0.02 & 100 & 0.33 & 0.74 \\
\hline 2008 & 0.01 & 0.01 & 100 & 0.46 & 0.65 & 0.01 & 0.02 & 100 & 0.31 & 0.76 \\
\hline 2009 & 0.01 & 0.01 & 100 & 0.49 & 0.63 & 0.00 & 0.03 & 100 & 0.16 & 0.88 \\
\hline 2010 & 0.00 & 0.01 & 100 & 0.24 & 0.81 & 0.01 & 0.02 & 100 & 0.36 & 0.72 \\
\hline 2011 & 0.00 & 0.01 & 100 & 0.27 & 0.79 & 0.01 & 0.02 & 100 & 0.43 & 0.67 \\
\hline \multicolumn{11}{|c|}{ Full Model } \\
\hline 2004 & 0.00 & 0.01 & 100 & 0.20 & 0.84 & 0.01 & 0.02 & 100 & 0.47 & 0.64 \\
\hline 2005 & 0.00 & 0.01 & 100 & 0.06 & 0.96 & 0.01 & 0.02 & 100 & 0.55 & 0.59 \\
\hline 2006 & 0.00 & 0.01 & 100 & 0.35 & 0.72 & 0.00 & 0.02 & 100 & 0.25 & 0.80 \\
\hline 2007 & 0.01 & 0.01 & 100 & 0.41 & 0.68 & 0.01 & 0.02 & 100 & 0.30 & 0.76 \\
\hline 2008 & 0.01 & 0.01 & 100 & 0.48 & 0.63 & 0.01 & 0.02 & 100 & 0.33 & 0.74 \\
\hline 2009 & 0.01 & 0.01 & 100 & 0.54 & 0.59 & 0.00 & 0.03 & 100 & 0.14 & 0.89 \\
\hline 2010 & 0.00 & 0.01 & 100 & 0.24 & 0.81 & 0.01 & 0.02 & 100 & 0.38 & 0.70 \\
\hline 2011 & 0.00 & 0.01 & 100 & 0.25 & 0.80 & 0.01 & 0.02 & 100 & 0.43 & 0.67 \\
\hline
\end{tabular}




\section{J. APPENDIX II}

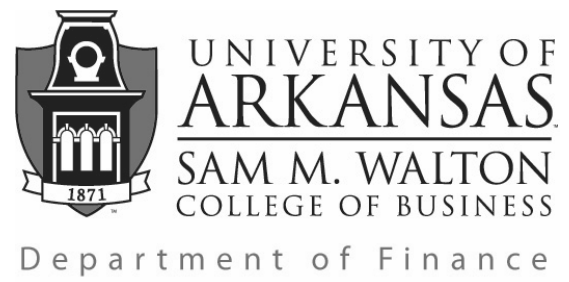

Timothy J. Yeager

Arkansas Bankers Association Chair in

Banking

\author{
University of Arkansas \\ Business Building 302 \\ Fayetteville, AR 72701-1201 \\ (479) 575-2992 (Tel) \\ (479) 575-8407 (Fax) \\ tyeager@walton.uark.edu
}

Santiago Barraza's dissertation contains two essays that are co-written with me and my colleague, Professor Wayne Lee. These essays are titled Financial Crisis and the Supply of Corporate Credit, and Banking Crises: Government Intervention and the Recovery of the Bank Credit Market. Santiago is the first author of each essay, and for each he has completed at least $51 \%$ of the work.

\section{Tim Yeager}

Associate Professor of Finance 


\title{
III. ESSAY 2: BANKING CRISES: GOVERNMENT INTERVENTION AND THE RECOVERY OF THE BANK CREDIT MARKET
}

\author{
J. Santiago E. Barraza, Wayne Y. Lee, and Timothy J. Yeager
}

\section{A. ABSTRACT}

We assess the effectiveness of the extraordinary government and central bank intervention on bank lending during the 2007-2009 financial crisis by comparing lending patterns from that crisis with the banking credit crunch of 1990-1992. Although the financial crisis was by every measure more severe than the credit crunch, the supply of bank credit rebounded two years sooner. We show that government and central bank intervention accounts for the differing dynamics in bank credit markets. Our results confirm that expansionary monetary and fiscal policy aimed at easing bank distress following a banking crisis can alleviate the damaging effects from the contraction in bank lending.

Keywords: financial crisis, government intervention, resolution mechanisms, credit supply

JEL Codes: G12, G21, G32

\section{B. INTRODUCTION}

The most crucial role of financial intermediaries (FI) is to facilitate the flow of funds from net savers to net borrowers. A disruption in this service can lead to a sudden contraction in output from reduced levels of consumption and investment (Bernanke, 1983; Gan, 2007; Jiménez, Ongena, Peydró, and Saurina, 2012; Barraza, Lee, Yeager, 2014). The ability of FI to add value in this process depends on their financial strength; the risk -and potential cost- posed by distressed FI can outweigh the benefit derived from their special ability to resolve information asymmetry problems and liquidate assets. In the event of FI's general distress, governments can decide to 
either engage or not in improving their conditions. The higher the systemic risk the banking distress poses, the greater the incentives for government to act.

In this paper we analyze the banking crises of 1990-1992 and 2007-2009. We show that the government's significant efforts to strengthen the banking sector in the recent financial crisis made the bank lending crisis to be relatively short-lived despite the acuteness of the sector general distress. In contrast, the lack of government intervention in the early 1990s episode of banking distress resulted in a long-lasting credit crunch. We show that while the proportion of distressed banks was comparable across both crisis, the size and systemic importance of the banks affected in the recent financial crisis was significantly higher. This provided a set of incentives for massive government intervention.

\section{The Early 1990s Banking Crisis}

The early 1990s witnessed a period of distress in the banking sector that resulted in a bank credit crunch. In a sense, the distress in the banking industry was a continuation of that initiated in 1985 with the savings and loans (S\&L) associations. However, the fall in commercial and industrial (C\&I) loans provided by commercial banks was a distinctive feature of the first years of the 1990s. Berger and Bouwman (2013) refer to the period between 1990:Q1 and 1992:Q4 as a banking crisis, yet it is more commonly referred to as credit crunch (e.g. Bernanke and Lown, 1991) or capital crunch (e.g. Syron, 1991), provided the role bank capital shortages allegedly played in the credit crunch.

The financial literature has explored several potential causes leading to this crisis. Bernanke and Lown (1991) and Syron (1991) have argued that a bank capital crunch drove the credit crunch. The former authors assert that the combination of sustained bank losses during the 
late 1980s and the implementation of the Basel Accord likely forced banks to restrain asset growth -and with it credit growth- in order to satisfy capital requirements. The Federal Deposit Insurance Corp. (FDIC) (1997) and Hall (1993) also argue that the implementation of risk-based capital requirements could have caused the credit crunch. Distinctively, Hall (1993) suggests that the lower capital requirements on securities led banks to substitute securities for loans on their portfolios of assets, thus reducing the supply of credit.

Despite regional heterogeneity in both the size and origin of the loan losses, researchers generally agree that the Northeast area of the United States was the most affected one, given substantial losses derived from real estate loans. Peek and Rosengren (1995) document a significant capital crunch in New England -where real estate loan losses were particularly sizeableand present evidence consistent with a credit crunch -yet not definitive in their own words.

Bankers and politicians have also blamed overzealous regulators for the credit crunch. However, researchers have found little evidence to support this hypothesis, as we can learn from Bernanke and Lown (1991), Clair and Tucker (1993) and Darin and Walter (1994).

Studies on systemic banking crises have been relatively silent on the early 1990s episode. This is probably partly due to the fact that the definition of such events often requires significant government intervention to identify the episode. This is the case, for instance, of Laeven and Valencia (2013) who do refer to 1988 as a borderline case of systemic banking crisis however.

\section{The Late 2000s Banking Crisis}

The late 2000s crisis started with the spike in the defaults on subprime mortgages, which led to the fallout of the market for mortgage-backed securities (MBS) in the second half of 2007. A run on Countrywide, a leading subprime originator in the United States, marked an early 
milestone for a nascent crisis in August of 2007. In the fourth quarter of 2007, banks with significant stakes in the MBS market became exposed to significant potential losses, largely as a result of absorbing the structured investment vehicles that had marketed the MBS. Bear Stearns, with a substantial exposure to collateralized debt obligations (CDO), had come under distress as early as June of 2007 and resulted absorbed by JP Morgan in March of 2008 in a Federal Reserveassisted transaction.

Gorton and Metrick (2012) thoroughly describe the dynamics and key transmission mechanisms of this crisis. Initiated with defaults on subprime mortgages, the crisis developed via the freezing of several short-term credit markets, which had become an indispensable source of financing for large and systemically important financial institutions. September and October of 2008 saw the height of the crisis, with Fannie Mae and Freddie Mac being taken over by the Federal government, Washington Mutual seized by the Federal Deposit Insurance Corporation (FDIC), AIG heavily assisted by the Federal Reserve, Lehman Brothers filing for bankruptcy, the Congress passing the Troubled Assets Relief Program (TARP), and the nine largest banks in the U.S. recapitalized by the Treasury.

The reach and severity of the financial crisis prompted to government to intervene decisively. And the magnitude of the government assistance programs has probably precedents only in the Great Depression.

\section{DIFFERING SEVERITY OF CRISES}

\section{Differing Severity of Crises: Banking System Conditions}

We have mentioned above that while the early 1990's crisis affected mostly small- and mid-size banks, the late 2000s crisis hit with particular virulence the largest banks in the financial 
system, making it a systematically important crisis. Moreover, while the former was moderate and protracted, the latter was acute and short-lived. We argue that the fact that the latter was shortlived is chiefly the result of the massive government intervention -which contrasts with the lack of assistance in the earliest crisis.

Figure 1 shows this aspect of the both crises. We use data from the FDIC bank failures or assistances to show that while the proportion of distressed banks was similar across crises -as shown by the small-dot line-, the assets of failed or assisted banks where considerably larger in the recent crisis - as shown by the large-dot line. The continuous line plots the asset-weight average expected default frequency of financial firms -standard industry codes 6000 through 6999- in the Compustat Annual and CRSP databases, and highlights the considerably larger magnitude of the recent crisis.

[Insert Figure 1 here.]

\section{Differing Severity of Crises: Fall in Bank Loans and Economic Growth}

The literature on both of these crises has established a tight relationship between banks' capital and solvency conditions and their ability to supply credit. Evidence from the early crisis includes Bernanke and Lown (1991) and Hancock and Wilcox (1998) while evidence from the recent crisis includes Barraza, Lee, and Yeager (2014) and Gambacorta and Marques-Ibanez (2011). Becker and Ivashina (2014) also provide evidence from time series tests that encompass both episodes.

The sizeable government programs to recapitalize banks and provide them with liquidity during the recent financial crisis contributed to a fast recovery of the bank credit market when compared to the credit crunch. Figure 2 below shows that while the 1990 s crisis brought four years 
of bank credit fall, the 2000s crisis only carried two years of fall, despite its considerably higher severity.

To build this figure we use the monthly stock of C\&I loans from all commercial banks in the U.S., provided by the Board of Governors of the Federal Reserve System. ${ }^{26}$ We adjust the series to 2010 US dollars using the consumer price index for all items from the Organization for Economic Co-operation and Development (OECD) ${ }^{27}$ The loan series shows that after reaching a peak in September 1989, C\&I started a long and steady decrease through December 1993. During the 51 months of fall the volume of outstanding C\&I dropped by $21.9 \%$ in real terms. In contrast, during the recent financial crisis loans peaked in November 2008, declined sharply through November 2010 -particularly sharply through the first quarter of 2010- and in all the stock of C\&I fell by $26.4 \%$ in real terms in only 24 months. ${ }^{28}$

\section{[Insert Figure 2 here.]}

Furthermore, the changes in economic activity that accompanied both crises are also different. According to the National Bureau of Economic Research (NBER) the economy reached a peak in July of 1990 and went into recession through March of 1991. The drop in real gross

\footnotetext{
${ }^{26}$ FRED data series BUSLOANS.

${ }^{27}$ FRED data series CPALTT01USM661S.

${ }^{28}$ The series BUSLOANS series also shows a significant drop during the early 2000s, which we omit in this analysis provided this is widely thought to correspond to fall on demand for credit, both in the bank and public markets.
} 
domestic product between 1990:Q3 and 1991:Q1 was 1.32\% and by 1991:Q4 had already surpassed its 1990:Q3 level -i.e. little after a year later. For the recent crises, the economy reached a peak in December of 2007, and went into recession through June of 2009. The drop in real gross domestic product between 2007:Q4 and 2009:Q2 amounted to 4.26\% and only in 2011:Q2 surpassed the level of 2007:Q4 -i.e. three and a half years later. Figure 3 shows the quarterly evolution of real gross domestic product between 1986 and March 2014.

\section{[Insert Figure 3 here.]}

\section{THE CRISES: TIMING, SEVERITY, AND RESPONSES}

In this section we present further details on the timing, severity, policy response, and pace of recovery from both crises using data on bank loans and public markets instruments. Table 1 presents two panels with robust insights using data from different sources.

\section{[Insert Table 1 here.]}

Dating banking crises is a challenging process that requires not only objective data but also judgment calls, as has been noted by authors such as Reinhart and Rogoff (2009), Laeven and Valencia (2013), and Laeven and Valencia (2014). For instance, distress can spread unevenly across different types of financial intermediaries or regions, displaying some of them clearly identifiable crisis characteristics, but not the others. It becomes then handy to rely on easily identifiable events that pertain to crises, such as government interventions. However, this identification strategy can miss episodes of banking distress with real consequences in the banking sector, and such is the case of the 1990s credit crunch, typically omitted among the banking crises.

Provided our ultimate purpose is to study the role of bank distress and government 
intervention on availability of corporate credit, in this section we date the banking crises based on the evolution of the bank credit market, an observable outcome of bank distress. The top part of Panel A in Table 1 synthesizes the information provided while discussing Figure 1; it shows that based on bank C\&I credit growth, the early crisis started in the last quarter of 1989 and lasted 51 months, more than twice the 24 months the late crisis lasted. Despite the noticeably different duration of these crises, the total changes in stock of $\mathrm{C} \& \mathrm{I}$ loans remained comparable across crises, with falls of respectively $21.9 \%$ and $26.4 \%$ for the early and late crises. Speed of change in the stock of loans is the key to differentiate both crises. While the annualized growth rate of C\&I loans during the early crisis was $-5.8 \%$, that rate almost tripled to reach $-15.3 \%$ during the 2000 s crisis.

Since both crisis events partially overlap with economic contractions, it is a necessary to account for the extent to which demand could have potentially driven the fall in bank credit. A straightforward strategy to address this issues is to maintain a reference point in an alternative credit market, such as the public debt market. Thus in Panel A we present data on new issues of both syndicated bank loans and non-convertible bonds, two relatively close substitute sources of credit. In the early 1990s crisis, syndicated loan issuances fell by $54.8 \%$ while non-convertible bond issuances rose by $13.8 \%$, suggesting that it is unlikely demand explains the changes in the bank debt market. Similarly, while syndicated loan issuances fell by $75.4 \%$ during the late $2000 \mathrm{~s}$ crisis, non-convertible bond issuances increased by 63.1\%. Barraza, Lee, and Yeager (2014) have documented that the bank credit rationing observed in the recent financial crisis actually induced firms with unsatisfied demand for credit to migrate from the bank to the public debt market.

At this point, it is worth noticing the different timing of credit market conditions we can observe from debt issuances and stocks of debt. While loan issuances can quickly reflect changes in the credit market conditions, stocks of loans will necessarily display a lag with respect to such 
changes. This is so because a considerable part of bank lending is made under commitments, and the customers' choice to draw down on their existing credit lines -thus modifying stocks of loanswill not necessarily reflect the current supply conditions. Hence, for instance, given a contraction in the credit supply, stock of loans could still grow if there was a fast enough pace of drawdowns on existing lines. Ivashina and Scharstein (2010) have already made this point arguing that the increase in stocks of C\&I observed during 2008 was likely due to drawdowns on existing commitments. The increase in the pace of drawdowns is typically fueled by borrowers' fear of lacking funding alternatives in the near future. Using data on generation of syndicated loans both Ivashina and Scharfstein (2010) and Barraza, Lee, and Yeager (2014) have shown that the bank credit generation indeed dropped markedly during the entire 2008, after peaking in late 2007.

Data on new issuances indicate that for the early crisis loan creation started falling in 1988:Q4, reaching a trough in 1991:Q1. In the recent crisis, loan creation started falling in 2007:Q3, reaching a trough in 2009:Q2 ${ }^{29}$. This means that new issuances fell during 30 and 24 months in the early and late crisis, respectively. Loan issuances in the early crisis, however, only reached the 1988:Q3 level five years later, in 1993:Q3, showing again a very slow recovery in the bank credit market.

We report next the size of government intervention during both crises using data from Laeven and Valencia (2013) and (2014). As we have mentioned, during the early 1990s there was

\footnotetext{
29 The year 2007 as a whole was still a year of bank credit expansion though. This aspect is relevant to our analysis below on borrower migration.
} 
no government intervention ${ }^{30}$. In stark contrast, the government response to the recent financial crisis was massive. Laeven and Valencia (2013) estimate liquidity support to have amounted to $4.7 \% \%^{31}$, and programs with impact on fiscal costs to have amounted to $4.5 \%$ of the GDP ${ }^{32}$. In addition, asset purchases programs amounted to $9.0 \%$ of the GDP -Laeven and Valencia (2014).

Based on data from stocks of C\&I loans, the pace of recovery from both crises seem comparable. C\&I loans grew at 7.6\% in the first two years of recovery starting on January 1994 and December 2010.

For robustness purposes, Panel B of Table 1 shows similar statistics to Panel A using data from the levels of nonfinancial corporate liabilities on the Z.1 release of the Board of Governors. Nonfinancial corporate bank debt is the quarterly stock of loans from depository institutions.

${ }^{30}$ Laeven and Valencia (2013) report as a borderline banking crisis the year 1988 though. For this year, they register a small government intervention of $0.1 \%$ and some more sizeable programs which amounted to $3.7 \%$ of the GDP.

${ }^{31}$ Liquidity support indicates liquidity support from the central bank, measured as the ratio of central bank claims on deposit money banks (line 12 in IFS) and liquidity support from the Treasury to total deposits and liabilities to nonresidents. Total deposits are computed as the sum of demand deposits (line 24), other deposits (line 25), and liabilities to nonresidents (line 26).

${ }^{32}$ Fiscal costs are defined as the component of gross fiscal outlays related to the restructuring of the financial sector. They include fiscal costs associated with bank recapitalizations but exclude asset purchases and direct liquidity assistance from the treasury. 
Nonfinancial corporate market debt is the quarterly stock of corporate bonds and commercial papers. As before, we transform the series to real terms. Our estimate of duration for the early crisis is now 45 months - 15 quarters, in fact-, and for the latest crisis it is 21 months -i.e. 7 quarters, closely matching our previous estimates. We also find that (1) the speed of bank credit fall during the recent crisis was almost four times that of the early crisis, (2) the fall in bank credit was accompanied by a rise in public market credit, and (3) the recovery pace after two years following the trough was close to $8 \%$.

There is yet another dimension on which we can compare government intervention across crises, namely the interest rate on the Federal Funds market, where the Federal Reserve exerts its monetary policy. While the effective federal funds rate averaged 5.29\% between October 1989 and December 1993, it average 0.17\% between December 2008 and November 2010. This reflects again a clearly more aggressive strategy to facilitate bank credit recovery from the recent financial crisis when compare with the credit crunch of the early 1990s.

\section{E. DEMAND VS. SUPPLY: EVIDENCE FROM BORROWING MIGRATIONS \\ 1. Steady States and Conditional Probabilities of Borrowing Outcomes}

The persistence of the credit crunch in the early 1990s crisis results evident in Hancock, Laing, and Wilcox (1995) where, using impulse-response analysis, the authors show that loan portfolios adjusted to shocks more slowly than capital did. The economic interpretation is that of a long-lived credit crunch when compared to the duration of the capital crunch. Our evidence in this section, derived from both steady states of credit markets and borrowing transition matrices following Barraza, Lee, and Yeager (2014), is consistent with the long-lived credit crunch.

Table 2 presents results of Markov migration analysis for firms that borrow from either the 
syndicated loans or the public debt market. In panel A, the column header reading 1989-1990, for instance, represents the steady state distribution of firms' borrowing outcomes should the credit market dynamics observed between 1989 and 1990 last for a long enough period of time. To construct the steady state, we observe each firm's borrowing outcome in both 1989 and 1990. Each year, a firm can borrow (1) no debt, (2) bank debt, (3) public debt, or (4) both bank and public debt. The aggregate of firms' borrowing outcomes in 1989 and 1990 are captured by two column vectors representing the proportion of firms in each borrowing outcome each year. These two vectors are linked by a four-by-four migration matrix that describes the passage of firms from a borrowing outcome in year $t$ towards a borrowing outcome in year $t+1$. Operating with the migration matrix, we derive the steady state vector of borrowings for the $1989-1990$ period. ${ }^{33}$ This vector can then be thought of as the long-term credit market equilibrium under the 1989-1990 credit market conditions.

\section{[Insert Table 2 here.]}

The first four steady state vectors in panel A of Table 2 show that between 1990 and 1993 the proportion of firms borrowing exclusively bank loans averaged $33.75 \%$ of the firms in the debt market, well below the $43 \%$ average in the rest of the 1990s and historical average of $42 \%$ between 1989 and 2011. Concurrently, the proportion of firms securing public debt rose to an average 17\% between 1991 and 1993, evidence of firms substituting public for bank debt at the time. And this is consistent with the fall in bank debt issuances being driven by supply factors, as opposed to demand factors. The first four columns in panel B show consistently low probabilities of securing

\footnotetext{
${ }^{33}$ See for details Barraza, Lee, and Yeager (2014).
} 
bank debt conditional on securing public debt during the period 1990-1993 -23.5\% in average, compared to $41.8 \%$ for the entire sample period- and consistently high probabilities of securing public debt conditional on securing bank debt between 1991-1993-14.5\%, compared to $9.8 \%$ average for the entire sample period-, further evidence of debt substitution.

The steady states corresponding to the 2000s financial crisis depict a shorter duration of the fall in bank credit. First, it must be noted that the 2006-2007 steady state vector does not present signs of bank credit contraction. That is to say, from 2006 to 2007 firms migrated between debt choices without visible constrains on an annual aggregate basis. The $46 \%$ of firms not borrowing is very close to the $47 \%$ all-time average, and the same is true for firms borrowing bank debt $-45 \%$ vs. $42 \%$ - or both bank and public debt -5\% vs. 5\%-. The fall in bank credit in late 2007 mentioned above seems to be offset by a rise in bank credit early that year.

The bank credit contraction is indeed noticeable between 2008 and 2009 -that is, vectors labeled 2007-2008 and 2008-2009. The most noticeable aspect of 2008 is the high level of firms securing no debt, whose $58 \%$ is significantly higher than both the preceding year and the historical average. Furthermore, the proportion of firms securing only bank debt drops to just $32 \%$ from $45 \%$ in the previous year, while the portion of firms securing only public debt almost doubles to $7 \%$ from $4 \%$ in the previous year. The steady state shows two noticeable aspects of the 2009 equilibrium, which is the all-time record low $25 \%$ of firms securing only bank debt, and the 17 year high proportion of firms securing only public debt, at $15 \%$ of the market.

The conditional probability analysis on panel B shows, accordingly, a very high likelihood of securing public debt conditional on securing bank debt during this during 2009 and 2010, and a very low probability of securing bank debt conditional on securing public debt, particularly in 
2008 and 2009. In 2010, the moderate probability of securing bank debt conditional on securing public debt together with the relatively high probability of securing public debt conditional on securing bank debt are consistent with firms diversifying their funding sources in the post-crisis, as observed in Barraza, Lee, and Yeager (2014).

\section{Market Dynamics: Borrowing Migrations}

We would like to gain next a better insight into the dynamics of the bank and public credit markets during both crises. To that effect, we present in Table 3 the average transition matrices for the crisis periods 1989-1993 in panel A, 2007-2009 in panel B, as well as the combined non-crisis periods 1993-2007 and 2009-2011 in panel C, and the entire sample period 1989-2011 in panel D.

[Insert Table 3 here.]

We want to highlight first the striking similarities between the dynamics of both crisis periods. Both crises were characterized by noticeable bank credit rationing and high levels of migration from bank debt to public debt. As much as $73 \%$ and $75 \%$ of the firms migrated from bank debt to no debt in the early and recent crisis, respectively, in comparison with a $60 \%$ average during the non-crisis periods. Similarly, those firms initially borrowing both bank and public debt, migrated to public debt exclusively in a $29 \%$ and $31 \%$ of the cases during both crises, in contrast with an average $13 \%$ in non-crisis periods, noticeably leaving the bank credit market in search for funding from the public. Both crises were also characterized by a high persistence of public debt borrowers. For the early and late crises, respectively $47 \%$ and $43 \%$ of those clients initially borrowing only public debt remained exclusively in the same market during the next year, in contrast with an average $27 \%$ during the non-crisis years.

All in all, the dynamics of the credit markets provide strong and consistent evidence of 
bank credit contraction and funding substitution, and a particularly lengthy duration of the credit crunch in the 1990 s crisis.

\section{F. FINANCIAL DISINTERMEDIATION AS A RESULT OF BANKING CRISES}

The ability of FI to efficiently channel funds from investors to firms depends on their own solvency conditions. In particular, arm's length lending becomes relatively more attractive to investors than intermediated lending when FI find themselves under distress. Thus, during periods of banking crisis, it should be preferable for investors to bypass FI and fund non-financial firms directly. We show below that banking crises indeed propitiate financial disintermediation.

Figure 4 presents the percentage of public debt issuances by firms in the banking sector ${ }^{34}$ and non-financial firms over time, from SDC Platinum data on non-convertible bonds. The graph shows that during both the 1990s and the 2000s crises investors were more prone to lend directly to non-financial firms than in previous years, bypassing FI. For the latest crisis, disintermediation peaked in 2009, and started decreasing after that. Hence it seems plausible a byproduct of banking crises is a temporary disintermediation process that tends to revert once FI are back to stable conditions.

[Insert Figure 4 here.]

\section{G. CONCLUSION}

In this paper we have analyzed the severity of the banking crises of early 1990s and late

\footnotetext{
${ }^{34}$ Industry number 45 in the Fama and French 49-industry classification, excluding Federal credit agencies such as Freddie Mac and Fannie Mae. Fama and French (1997).
} 
2000s. We have shown that the former was moderate yet protracted and carried a total fall in bank credit that is comparable to that observed in the most recent crisis. We have argued that the recent financial crisis was more severe in terms of the size and systemic importance of the banks under distress, despite the comparability of the number of distress institutions. The systemic risk posed by the recent crisis led to quick and massive government responses, which rapidly curved banking distress and promoted a swift recovery in the bank credit market. This point highlights the importance of decisive government interventions. While it remains plausible that government intervention poses the risk of engendering future moral hazard, it also remains safe to assume that it can have a powerful healing effect on bank credit markets and economic activity. 


\section{H. REFERENCES}

Barraza, J. Santiago E., Wayne Y. Lee and Timothy J. Yeager, 2014, Financial Crisis and the Supply of Corporate Credit. Working Paper, SSRN \#2422678.

Becker, Bo and Victoria Ivashina, 2014, Cyclicality of Credit Supply: Firm Level Evidence, Journal of Monetary Economics, 62, 76-93.

Berger, Allen N. and Christa H.S. Bouwman, 2013, How Does Capital Affect Bank Performance during Financial Crises, Journal of Financial Economics, 109, 146-176.

Bernanke, Ben S. and Cara S. Lown, 1991, The Credit Crunch, Brookings Papers on Economic Activity, 1991-2, 205-247.

Clair, Robert T. and Paula Tucker, 1993, Six Causes of the Credit Crunch, Federal Reserve Bank of Dallas Economic Review, Third Quarter 1993, 1-20.

Darin, Robert M., and John R. Walter, 1994, Were bank Examiners Too Strick with New England and California banks? Federal Reserve Bank of Richmond Economic Quarterly, 80-4, 25 47.

Fama, Eugene F. and Kenneth R. French, 1997, Industry Costs of Equity, Journal of Financial Economics, 43, 153-193.

Federal Deposit Insurance Corporation, 1997, History of the Eighties, Volume I: An Examination of the Banking Crises of the 1980s and Early 1990s, Volume II: Symposium Proceedings January 16, 1997.

Gambacorta, Leonardo and David Marques-Ibanez, 2011, The Bank Lending Channel: Lessons from the Crisis, Economic Policy 26-66, 135-182.

Gan, Jie, 2007, The Real Effects of Asset Market Bubbles: Loan- and Firm-Level Evidence of a Lending Channel, Review of Financial Studies 20-6, 1941-1973.

Hancock, Diana, Andrew J. Laing, and James A. Wilcox, 1995, Bank Capital Shocks: Dynamic Effects on Securities, Loans, and Capital, Journal of Banking and Finance 19, 661-677.

Hancock, Diana, and James A. Wilcox, 1998, The "Credit Crunch"and the Availability of Credit to Small Business, Journal of Banking and Finance 22, 983-1014.

Ivashina, Victoria and David Scharfstein, 2010, Bank Lending During the Financial Crisis of 2008, Journal of Financial Economics 97, 319-338.

Jiménez, Gabriel, Steven Ongena, José Luis Peydró, Jesús Saurina, 2012, Credit Supply and Monetary Policy: Identifying the Bank Balance-Sheet Channel with Loan Applications, American Economic Review, 102-5, 2301-2326.

Laeven, Luc and Fabián Valencia, 2013, Systemic Banking Crises Database, IMF Economic Review, 61-2, 225-270. 
Laeven, Luc and Fabián Valencia, 2014, Resolution of Banking Crises: The Good, The Bad, and The Ugly, in Financial Crises: Causes, Consequences, and Policy Responses, edited by Stijn Claessens, M. Ayhan Kose, Luc Laeven, and Fabián Valencia. International Monetary Fund.

Peek, Joe and Eric Rosengren, 1995, The Capital Crunch: Neither a Borrower nor a Lender Be, Journal of Money, Credit and Banking 27-3, 625-638.

Reinhart, Carmen and Kenneth Rogoff, 2009, This Time Is Different: Eight Centuries of Financial Folly. Princeton University Press.

Syron, Richard F., 1991, Are We Experiencing a Credit Crunch? New England Economic Review, Federal Reserve Bank of Boston, July/Auguts 1991, 3-10. 


\section{Table 1: Banking Crises Statistics}

This table presents statistics on the duration and severity of the early 1990s and late 2000s banking crises. C\&I Loans is the monthly stock of outstanding commercial and industrial loans, from all commercial banks, provided by the Board of Governors of the Federal Reserve System. Syndicated loan issuances are new U.S. dollar denominated loans with maturity of at least 1 year, secured by U.S. nonfinancial corporations and marketed in the U.S., from Thomson Reuters DealScan. Non-convertible bonds are new issuances of U.S. dollar denominated bonds with maturiy of at least 1 year, secured by U.S. nonfinancial corporations and marketed in the U.S., from SDC Platinum. Volumes of syndicated loans and non-convertibles bonds are computed quarterly. In order to smooth out seasonal effects, volumes are converted to centered rolling windows; that is, the volume for quarter $t$ is the average volume between $t-1$ and $t+1$. This centering technique is meant to conserve the timerelated properties of the series. All series have been transformed to 2010 U.S. dollars, using the consumer price index: total all items for the United States, from the OECD. Data on government intervention are from Laeven and Valencia (2013) -liquidity support and fiscal cost (\%GDP)- and Laeven and Valencia (2014) -asset purchases-. In Laeven and Valencia (2013) Fiscal costs are defined as the component of gross fiscal outlays related to the restructuring of the financial sector. They include fiscal costs associated with bank recapitalizations but exclude asset purchases and direct liquidity assistance from the treasury. Liquidity support indicates liquidity support from the central bank, measured as the ratio of central bank claims on deposit money banks (line 12 in IFS) and liquidity support from the Treasury to total deposits and liabilities to nonresidents. Total deposits are computed as the sum of demand deposits (line 24), other deposits (line 25), and liabilities to nonresidents (line 26). 
Table 1: Banking Crises Statistics (Cont.)

Panel A: Data from C\&I Loans, Syndicated Loan Issuances, and Non-Convertible Bond Issuances

Start and Duration

First Fall in C\&I Loans

Early 1990s Late 2000s

Last Fall in C\&I Loans

Oct-89 Dec-08

Months of Fall in C\&I Loans

Dec-93 Nov-10

$51 \quad 24$

Total Bank Credit Percentage Change, Peak to Trough

C\&I Loans

$-21.9 \quad-26.4$

Pace of Bank Debt Fall: Annualized Growth Rate, Cont. Comp.

C\&I Loans

$-5.8$

$-15.3$

Pace of Recovery: Annualized Growth Rate, Cont. Comp.

C\&I Loans during the First Year

7.2

5.1

C\&I Loans during the First Two Years

7.6

7.6

Comparative: Total Percentage Change, by Credit Market, Peak to Trough

Syndicated Loan Issuances

$-54.8$

$-75.4$

Non-Convertible Bonds Issuances

13.8

63.1

Government Intervention

Liquidity Support

0.0

4.7

Fiscal Costs (\%GDP)

0.0

4.5

Asset Purchases (\%GDP)

0.0

9.0 


\section{Table 1: Banking Crises Statistics (Cont.)}

Nonfinancial corporate bank debt is the quarterly stock of loans from depository institutions on the liabilities of nonfinancial corporate business, from the Board of Governors of the Federal Reserve System Z.1 report. Nonfinancial corporate market debt is the quarterly stock of corporate bonds and commercial papers on the liabilities of nonfinancial corporate business, from the Z.1 release. All series have been transformed to 2010 U.S. dollars, using the consumer price index: total all items for the United States, from the OECD.

\section{Panel B: Data from BoG FRS Z.1 Release}

\section{Start and Duration}

First Fall Nonfinancial Corporate Bank Debt

Last Fall Nonfinancial Corporate Bank Debt

Months of Fall in Nonfinancial Corporate Bank Debt

Total Bank Credit Percentage Change, Peak to Trough

Nonfinancial Corporate Bank Debt

Early 1990s Late 2000s

$\begin{array}{cc}\text { 1990:Q1 } & \text { 2009:Q1 } \\ \text { 1993:Q3 } & 2010: Q 3 \\ \text { 45 } & 21\end{array}$

$-27.7$

$-43.4$

Pace of Bank Debt Fall: Annualized Growth Rate, Cont. Comp.

Nonfinancial Corporate Bank Debt

$-8.6 \quad-32.6$

Pace of Recovery: Annualized Growth Rate, Cont. Comp.

Nonfinancial Corporate Bank Debt during First Year

4.1

8.9

Nonfinancial Corporate Bank Debt during First Two Years

7.8

8.8

Comparative: Total Percentage Change, by Credit Market, Peak to Trough

Nonfinancial Corporate Bank Debt during First Year $-27.7$

Nonfinancial Corporate Market Debt during First Year

16.3

13.1 
Table 2: Steady States of Credit Markets

Panel A presents the steady state distributions of syndicated bank loans and public debt issues imputed from transition matrices computed for each of the six overlapping two-year periods between 2004 and 2010. Loans are syndicated bank loans to publicly traded firms. Bonds are public debt issues. In each year, we classify firms into one of four groups depending on whether the firm obtained: (i) no debt; (ii) loans only; (iii) bonds only; or (iv) both bank and public debt. The proportions of firms in each group at the beginning and end of each two-year period characterize an initial and a final state vector, and a Markov transition matrix describes the passage of firms to state $i$ in period $\mathrm{t}+1$ from state $j$ in period t. The steady state distributions are the long-run equilibriums implied by each set of two-year market dynamics. Panel B presents the conditional probabilities of securing bank (public) debt conditional on securing public (bank) debt. * denotes the value is significantly different from the average steady states between 1989 and 2011 at $10 \%$ or better.

\begin{tabular}{lcccccccc}
\hline \multicolumn{2}{l}{ Panel A: Steady State Dynics of Aggregate Debt Financing } \\
& $1989-$ & $1990-$ & $1991-$ & $1992-$ & $1993-$ & $1994-$ & $1995-$ & $1996-$ \\
& 1990 & 1991 & 1992 & 1993 & 1994 & 1995 & 1996 & 1997 \\
No Debt & 0.55 & 0.47 & 0.46 & 0.46 & 0.48 & 0.50 & 0.45 & 0.44 \\
Loans only & 0.39 & $0.28^{*}$ & 0.33 & 0.35 & 0.46 & 0.40 & 0.45 & 0.49 \\
Bonds only & 0.05 & $0.20^{*}$ & $0.16^{*}$ & 0.14 & 0.03 & 0.07 & 0.05 & 0.04 \\
Loans \& Bonds & $0.01 *$ & 0.05 & 0.05 & 0.06 & 0.03 & 0.04 & 0.05 & 0.03 \\
$\quad$ Firms & 1,454 & 1,510 & 1,678 & 1,916 & 2,197 & 2,308 & 2,608 & 3,014 \\
& $1997-$ & $1998-$ & $1999-$ & $2000-$ & $2001-$ & $2002-$ & $2003-$ & $2004-$ \\
& 1998 & 1999 & 2000 & 2001 & 2002 & 2003 & 2004 & 2005 \\
No Debt & 0.49 & 0.55 & 0.52 & 0.44 & 0.46 & 0.45 & 0.42 & 0.42 \\
Loans only & 0.41 & 0.39 & 0.43 & 0.45 & 0.48 & 0.46 & 0.54 & 0.52 \\
Bonds only & 0.07 & 0.03 & 0.02 & 0.04 & 0.02 & 0.03 & 0.01 & 0.02 \\
Loans \& Bonds & 0.03 & 0.03 & 0.03 & 0.07 & 0.05 & 0.06 & 0.03 & 0.04 \\
$\quad$ Firms & 3,176 & 3,014 & 2,706 & 2,582 & 2,645 & 2,565 & 2,455 & 2,328 \\
& $2005-$ & $2006-$ & $2007-$ & $2008-$ & $2009-$ & $2010-$ & $A v g$. & $S D$ \\
& 2006 & 2007 & 2008 & 2009 & 2010 & 2011 & $1989-$ & $1989-$ \\
No Debt & 0.44 & 0.46 & $0.58 *$ & 0.55 & 0.46 & $0.37 *$ & 0.47 & 0.05 \\
Loans only & 0.48 & 0.45 & 0.32 & $0.25^{*}$ & 0.38 & 0.49 & 0.42 & 0.08 \\
Bonds only & 0.03 & 0.04 & 0.07 & $0.15^{*}$ & 0.09 & 0.04 & 0.06 & 0.05 \\
Loans \& Bonds & 0.05 & 0.05 & 0.03 & 0.05 & 0.07 & $0.09 *$ & 0.05 & 0.02 \\
Firms & 2,268 & 2,106 & 1,995 & 1,783 & 1,595 & 1,686 & 49,589 & 49,589 \\
\hline
\end{tabular}


Table 2: Steady States of Credit Markets (Cont.)

\begin{tabular}{|c|c|c|c|c|c|c|c|c|}
\hline \multicolumn{9}{|c|}{ Panel B: Conditional Probabilities of Funding Choice } \\
\hline & $\begin{array}{c}1989- \\
1990\end{array}$ & $\begin{array}{c}1990- \\
1991\end{array}$ & $\begin{array}{c}1991- \\
1992\end{array}$ & $\begin{array}{r}1992- \\
1993\end{array}$ & $\begin{array}{r}1993- \\
1994\end{array}$ & $\begin{array}{c}1994- \\
1995\end{array}$ & $\begin{array}{r}1995- \\
1996\end{array}$ & $\begin{array}{r}1996- \\
1997\end{array}$ \\
\hline $\mathrm{P}$ (Bonds|Loans) & 0.030 & 0.163 & 0.131 & 0.141 & 0.062 & 0.090 & 0.095 & 0.066 \\
\hline \multirow[t]{2}{*}{$\mathrm{P}$ (Loans|Bonds) } & 0.194 & 0.214 & 0.240 & 0.291 & 0.506 & 0.365 & 0.496 & 0.466 \\
\hline & $\begin{array}{c}1997- \\
1998\end{array}$ & $\begin{array}{r}1998- \\
1999\end{array}$ & $\begin{array}{l}1999- \\
2000\end{array}$ & $\begin{array}{l}2000- \\
2001\end{array}$ & $\begin{array}{l}2001- \\
2002\end{array}$ & $\begin{array}{l}2002- \\
2003\end{array}$ & $\begin{array}{l}2003- \\
2004\end{array}$ & $\begin{array}{l}2004- \\
2005\end{array}$ \\
\hline P(Bonds|Loans $)$ & 0.076 & 0.066 & 0.067 & 0.140 & 0.091 & 0.108 & 0.049 & 0.064 \\
\hline \multirow[t]{2}{*}{ P(Loans|Bonds) } & 0.318 & 0.489 & 0.629 & 0.663 & 0.723 & 0.680 & 0.662 & 0.636 \\
\hline & $\begin{array}{r}2005- \\
2006\end{array}$ & $\begin{array}{l}2006- \\
2007\end{array}$ & $\begin{array}{c}200 \\
20\end{array}$ & & & 2009 & $\begin{array}{c}2010- \\
2011\end{array}$ & $\begin{array}{l}\text { Avg. } \\
1989- \\
2011\end{array}$ \\
\hline P(Bonds|Loans) & 0.086 & 0.106 & 0.0 & & & 0.152 & 0.160 & 0.098 \\
\hline P(Loans $\mid$ Bonds $)$ & 0.570 & 0.561 & 0.2 & & & 0.434 & 0.718 & 0.418 \\
\hline
\end{tabular}


Table 3: Average Borrowing Transition Matrices

This table shows average transition matrices by periods. Panel A covers the banking crisis period 1989-1993. The notation 1989-1993 means that it covers the four transition matrices from 1989 to 1990, from 1990 to 1991, from 1991 to 1992, and from 1992 to 1993.

Panel A: Crisis Average Transition Matrix (1989-1993)

\begin{tabular}{|c|c|c|c|c|}
\hline Final $\backslash$ Initial & No Debt & Loans only & Bonds only & Loans \& Bonds \\
\hline No Debt & 0.37 & 0.73 & 0.39 & 0.35 \\
\hline Loans only & 0.51 & 0.23 & 0.06 & 0.13 \\
\hline Bonds only & 0.10 & 0.02 & 0.47 & 0.29 \\
\hline Loans \& Bonds & 0.03 & 0.02 & 0.08 & 0.22 \\
\hline Firms & 889 & 563 & 144 & 44 \\
\hline \multicolumn{5}{|c|}{ Panel B: Crisis Average Transition Matrix (2007-2009) } \\
\hline Final \Initial & No Debt & Loans only & Bonds only & Loans \& Bonds \\
\hline No Debt & 0.52 & 0.75 & 0.41 & 0.32 \\
\hline Loans only & 0.38 & 0.19 & 0.07 & 0.14 \\
\hline Bonds only & 0.07 & 0.03 & 0.43 & 0.31 \\
\hline Loans \& Bonds & 0.02 & 0.03 & 0.08 & 0.23 \\
\hline Firms & 960 & 743 & 104 & 84 \\
\hline
\end{tabular}

Panel C: Non-Crisis Average Transition Matrix (1993-2007, 2009-2011)

\begin{tabular}{lcccc} 
Final \Initial & No Debt & Loans only & Bonds only & Loans \& Bonds \\
No Debt & 0.35 & 0.60 & 0.38 & 0.24 \\
Loans only & 0.59 & 0.35 & 0.20 & 0.32 \\
Bonds only & 0.03 & 0.01 & 0.27 & 0.13 \\
Loans \& Bonds & 0.02 & 0.03 & 0.15 & 0.31 \\
\multicolumn{1}{c}{ Firms } & 1,184 & 1,061 & 109 & 99 \\
\hline \multicolumn{2}{c}{ Panel D: All-Time Average Transition Matrix (1989-2011) } \\
Final \Initial & No Debt & Loans & Bonds & L \& B \\
No Debt & 0.37 & 0.64 & 0.39 & 0.27 \\
Loans only & 0.56 & 0.31 & 0.16 & 0.27 \\
Bonds only & 0.05 & 0.02 & 0.32 & 0.18 \\
Loans \& Bonds & 0.03 & 0.03 & 0.13 & 0.28 \\
\multicolumn{1}{c}{ Firms } & 1,110 & 942 & 115 & 88 \\
\hline
\end{tabular}




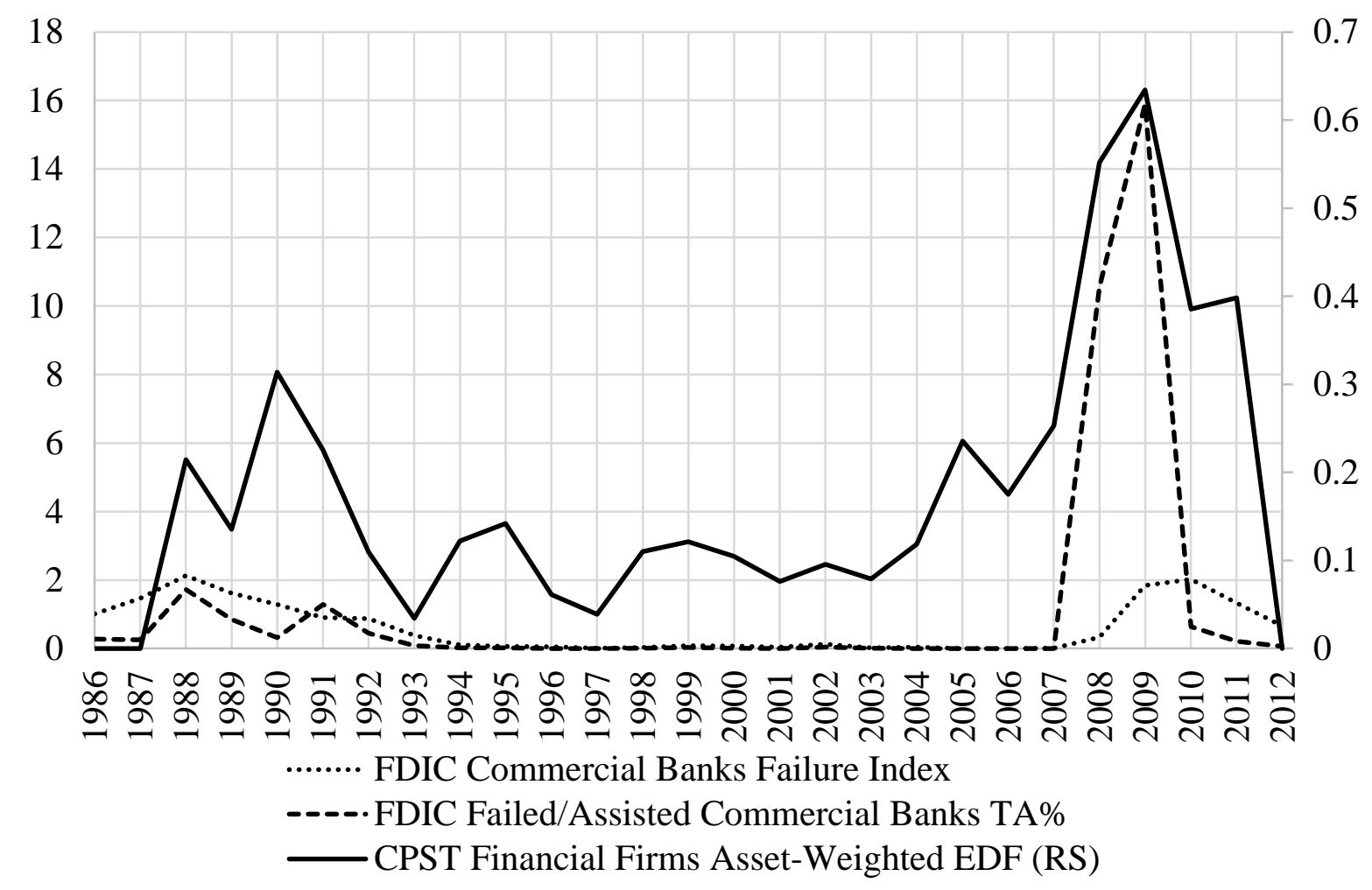

Figure 1. Banking Industry Distress. This figure shows three measures of banking system distress. Commercial Banks Failure Index is the number of FDIC failed or assisted commercial banks divided by the number of FDIC insured commercial banks. FDIC Failed/Assisted Commercial Banks TA\% is the total assets of FDIC failed or assisted banks scaled by the total assets of all FDIC-insured commercial banks. CPST Financial Firms Asset-Weighted EDF is the asset-weighted average EDF of financial firms in the Compustat Annual database (on the right scale). 


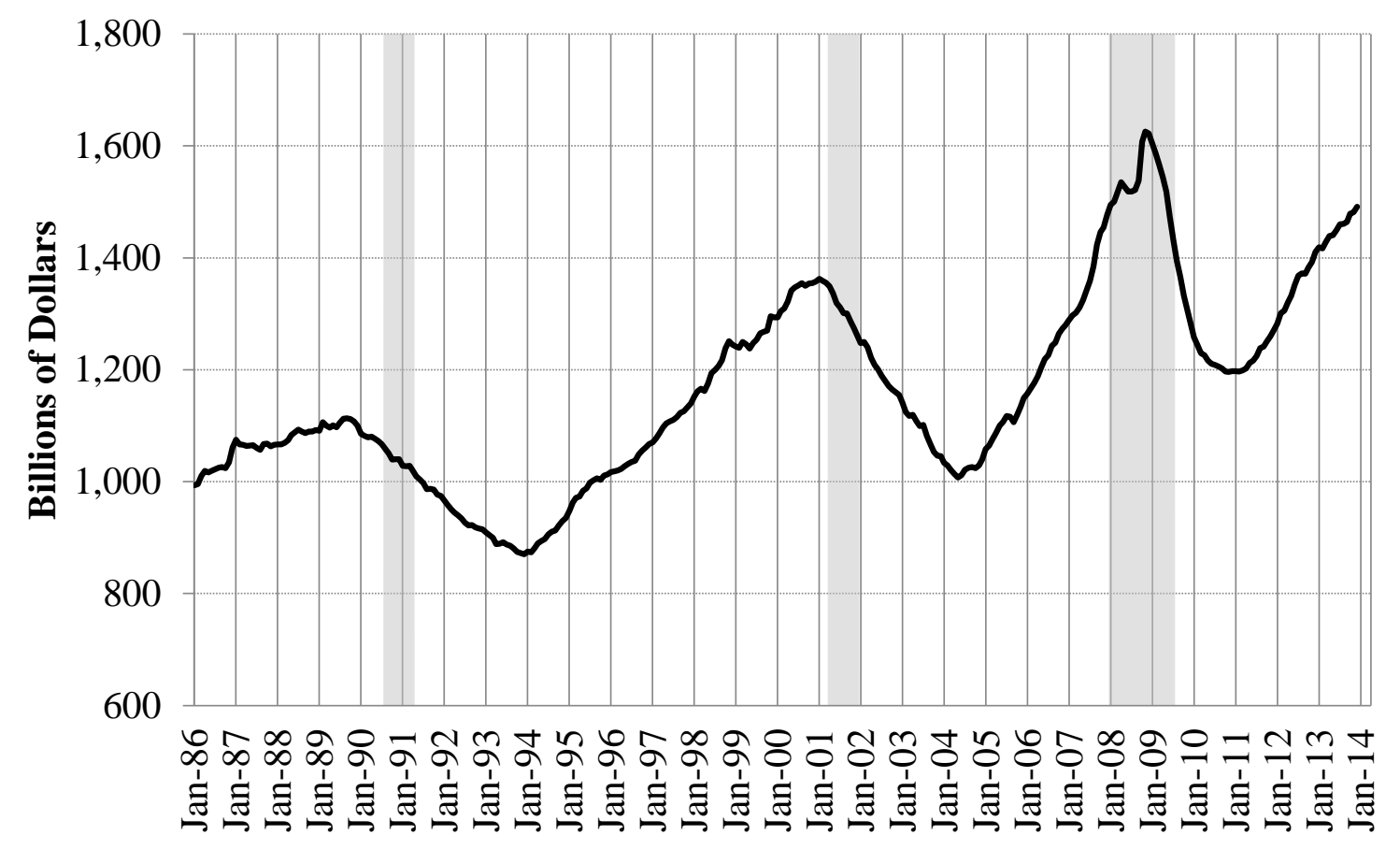

Source: Board of Governors of the Federal Reserve System/FRED

Figure 2. Commercial and Industrial Loans, All Commercial Banks. The figure plots the monthly stock values of commercial and industrial loans, from all commercial banks. The volumes are deflated and expressed in 2010 US dollars, using the consumer price index series. The shaded areas depict recession periods in the United States. 


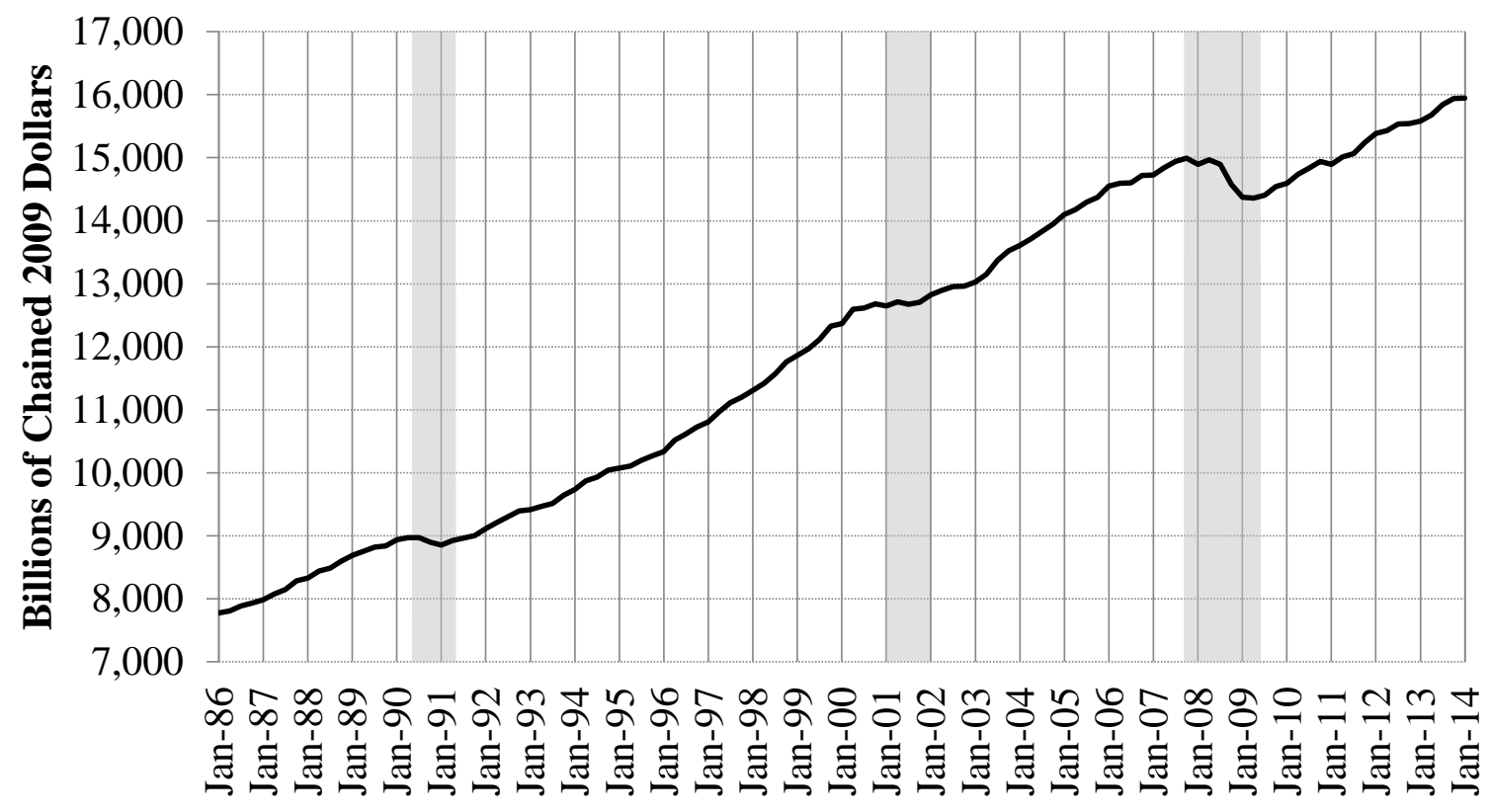

Source: U.S. Department of Commerce: Bureau of Economic Analysis/FRED

Figure 3. Real Gross Domestic Product. This figure plots quarterly real gross domestic product in billions of chained 2009 US dollars. Series GDPC1 from FRED. The shaded areas depict recession periods in the United States. 


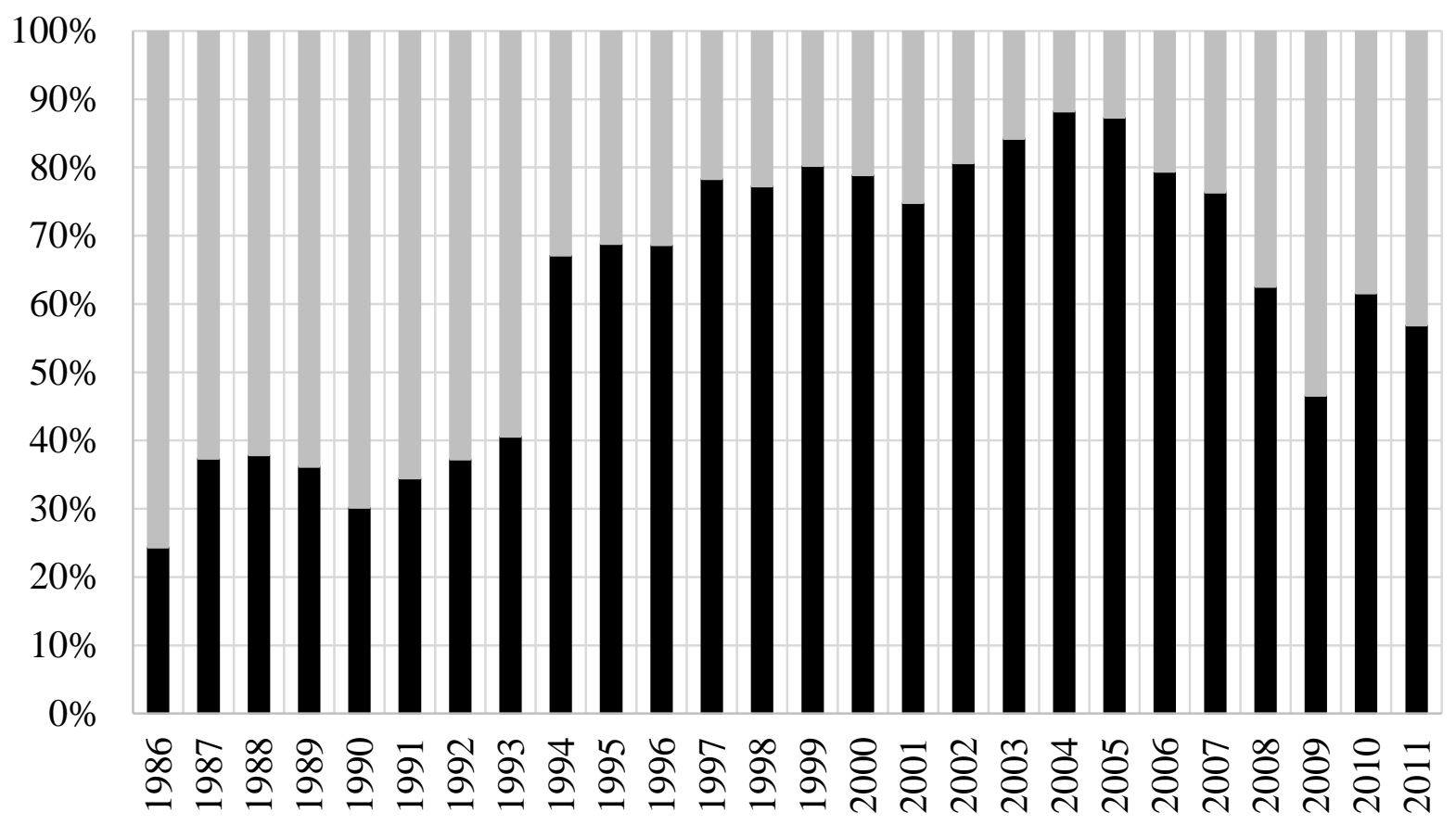

- Banking Non-Financial

Figure 4. Financial Intermediation: Percentage of Public Debt Issuances by Banking Sector and Non-Financial Borrowers. This figure plots the percentage of U.S. dollar-denominated nonconvertible bond issuances that correspond to the U.S. banking sector and to U.S. non-financial firms in the U.S. public market, from SDC Platinum. The banking sector is the industry number 45 in the Fama and French 49-industry classification, excluding Federal credit agencies, such as Freddie Mac and Fannie Mae. Non-financial firms are those with standard industry code less than 6000 or greater than 6999. 


\section{APPENDIX I}

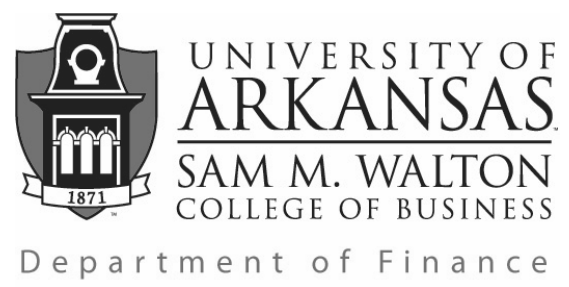

Timothy J. Yeager

Arkansas Bankers Association Chair in

Banking

\author{
University of Arkansas \\ Business Building 302 \\ Fayetteville, AR 72701-1201 \\ (479) $575-2992(\mathrm{Tel})$ \\ (479) 575-8407 (Fax) \\ tyeager@walton.uark.edu
}

Santiago Barraza's dissertation contains two essays that are co-written with me and my colleague, Professor Wayne Lee. These essays are titled Financial Crisis and the Supply of Corporate Credit, and Banking Crises: Government Intervention and the Recovery of the Bank Credit Market. Santiago is the first author of each essay, and for each he has completed at least $51 \%$ of the work.

Tim Yeager

Associate Professor of Finance 


\title{
IV. ESSAY 3: ECONOMIC DISTRESS AND THE MATURITY OF DEBT ${ }^{35}$
}

\author{
J. Santiago E. Barraza
}

\section{A. ABSTRACT}

This paper explores the relationship between aggregate economic distress and the maturity of debt. I argue that lenders would prefer shorter maturity of debt during periods of economic distress. I develop two lines of argument based on debt contracting to support this prediction, and the rationales rely heavily on the role that default risk and screening plays in lending transactions. In the first line of argument, a lender chooses the debt contract tenor that maximizes her expected profits. In doing so, she weighs the role of capital rotation with the expected margin on each transaction and the probability that the borrower defaults. The probability of the borrower defaulting depends on the aggregate economic conditions. As a result, a shock that reduces economic stability leads the lender to prefer shorter maturities on new debt contracts. The second argument builds on the concept of the lender's rollover option, which is her opportunity to relend her loanable funds after collection. During times of economic distress this option is more valuable to the lender, who increases her number of options by shortening the maturity of new contracts. Finally, I test these predictions empirically using over twenty years of U.S. bank and public debt issues to show a significant negative relationship between aggregate economic riskiness and maturity of new debt contracts. Moreover, shortening maturities result in changes in the temporal financial structure of public nonfinancial corporations.

\footnotetext{
${ }^{35}$ I am grateful to Amy Farmer, Salar Jahedi, Alexey Malakhov, and Kangzhen Xie for insightful comments and lengthy discussions on the early ideas of this paper. All errors remain solely mine.
} 
Keywords: debt maturity, credit supply, economic distress, probability of default, survivorship.

JEL Codes: G12, G21.

\section{B. INTRODUCTION}

The financial literature has recently highlighted the importance of debt maturity in corporate finance, particularly during financial crises. Some of the most interesting findings in this area are due to Almeida et al. (2011), who document the threat that maturing debt can pose on corporate investment when facing a shock on the supply of credit. He and Xiong (2012) have shown that an increase in assets' fundamental volatility can induce further distress on financial intermediaries and spur runs on them. Fan et al. (2012) have also documented that the maturity of corporate debt is, to a great extent, a function of the economic setup - as opposed to the economic activities of the firm itself - in a study of the cross section of thirty nine countries. Similarly, Gopalan et al. (2014) have shown that changes to improve contract enforcement lead to longer debt maturity, which, in turn, bolster long-term investment.

Theoretical works on the role of aggregate economic distress on nonfinancial firms as well as empirical tests in this regard remain relatively scarce, though. In this paper, I explore why and how the riskiness in the economic environment can shorten the debt maturity to the cross-section of firms, paying particular attention to tests on nonfinancial firms. From a perspective of cash-flow matching and financial frictions, the issue bears significant relevance to the financial literature, provided that shorter maturities on the firm liabilities impose restrictions on the portfolio of investment opportunities viable to the firm.

The dominant theoretical approaches to determinants of debt contract maturity in the 
financial literature rely on a principal-agent setup. In Flannery (1986), firms issue the type of security the markets overvalue the most. Investors know that firms act strategically and react accordingly. In a market with costly transactions, a separating equilibrium between good and bad (safest and riskiest, respectively) firms is possible. Good firms, considering their long-term debt relatively undervalued, issue short-term debt, and signal their quality to the market. Bad firms issue overpriced long-term debt.

Diamond (1991) develops a model with asymmetric information where, in choosing the optimal maturity, borrowers trade off their preference for short-term maturity due to an expected credit rating improvement with their preference for liquidity (risk). Good borrowers choose to issue short-term debt, somewhat riskier borrowers choose to issue long-term debt, and the riskiest ones are constrained to issue short-term debt.

The purpose of this paper is to examine the effects of increases in aggregate economic distress on the maturity of corporate debt. While new debt issues constitute the main thread of the argument and tests, additional tests on the maturity of balance-sheet liabilities from nonfinancial public firms demonstrate how far-reaching these effects are.

I develop a model of debt contracting that accounts for perhaps the single most important change observed during an economic crisis, i.e., an increase in the probability of default and failure of borrowers. An implicit assumption of this model is that lenders are powerful enough to set the maturity conditions on the new contracts. Although this assumption might look slightly strong at first sight, it is not necessarily detached from reality. Consider, for instance, that banks publish their required rates for given maturities and that, in doing so, they can effectively induce borrowers to choose the maturities of their preference. Further, firms issuing new public debt will typically 
scout credit markets in advance, in order to adapt the offerings to the current investors' preferences.

The analysis herein is then focused on the supply side of the credit market, and it assumes perfect information among the contracting agents. The main intuition -which I develop in two alternative yet complementary manners- is that lenders prefer shorter maturities when faced with increased levels of economic riskiness because the value they provide, in the form of flexibility and screening opportunities, increases with the uncertainty of future results. I show that increases in aggregate economic risk bring about shorter maturities not only in new credit contracts -bank loans and non-convertible bond issues- but also on the stock of liabilities on the balance-sheet of nonfinancial corporations.

The paper proceeds as follows: In sections II and III, I explore the reasons why, during periods of economic distress, we should expect to observe shorter maturities on new debt issuances. Section II develops a model of the lender's profit maximization problem, where the lender chooses the optimal contract tenor, given that her expected profit is a function of the margin on each lending transaction, the rotation of her stock of loanable funds, and the probability that borrowers pay back their loans. Section III further develops the intuition of the relationship between riskiness and maturity by focusing on the rollover option a lender has when lending repeatedly over time.

In section IV, I provide empirical evidence on the shortening of the maturity during periods of economic distress, using over twenty years of data on both debt contracts and stocks of corporate liabilities. Graphs, correlations, and multivariate tests all provide robust evidence consistent with the main hypothesis of this paper. Section V discusses the findings and possible extensions to this paper, and section VI concludes. 


\section{THE LONG-RUN LENDING PROFITABILITY IS A FUNCTION OF THE BORROWERS' PROBABILITY OF SURVIVAL, WHICH IS A FUNCTION OF THE CONTRACT TENOR}

This section develops a model wherein a lender who expects to have a long enough economic life maximizes her profits by choosing the optimal tenor of each contract she gives. The lender's profitability is a function of the expected transaction margin multiplied by the rotation of her loanable funds. While loan rotation is desirable, issuing new contracts repeatedly carries transaction costs that make higher rotation -and shorter maturities- less attractive.

Borrowers face a non-zero random probability of bankruptcy at any point in the future. Hence, the probability of borrower survival ${ }^{36}$ is decreasing in time, which makes shorter maturities more desirable. Shorter maturities reduce the lender's credit risk exposure and give her further screening opportunities.

One can safely argue that the probability of a business success or failure is determined, to a large extent, by the aggregate economic conditions. Hence, in this analysis the probability of a borrower's failure is a function of a parameter that accounts for the general economic riskiness. Thus the optimal contract maturity can be affected by an exogenous shock to this parameter.

In the next subsection, I set up the lender's problem and find the optimal contract tenor. Next, I estimate the comparative statics that derive from an exogenous shock to the risk in the economic environment. Crucially, the results show that the lender's optimal response to an increase in the riskiness in the economic environment is the shortening of the new contract

\footnotetext{
${ }^{36}$ Assuming any firm that goes bankrupt does not survive.
} 
maturities.

\section{Lender's Profit Maximization Problem}

Consider a lender whose profit maximization problem is a function of the expected profitability of each contract multiplied by the number of contracts she generates throughout her economic life. The profit maximization function is as follows:

$$
\pi=n[A \theta(l, z)-L-c L]
$$

With:

$n=V / l$

Where:

$\pi$ : profits.

$n$ : number of contracts issued by the lender during her economic life.

V: lender's expected economic life.

$l$ : contract tenor.

A: amount to be repaid by the borrower at maturity, which she will pay if her business has survived until that point in time ${ }^{37}$.

${ }^{37}$ Notice that, in this setup, the lender receives, at maturity, either $A$ or nothing. This is a simplification that does not necessarily restrict generality. As a matter of fact, $A$ can be thought of 
$\theta(l, z)$ : the cumulative distribution function of borrowers' probability of survival.

$z$ : a non-negative parameter representing the riskiness of the economic conditions. Importantly, the effect on firms of a positive change in $z$ is a decrease in their probability of survival -or an increase in their probability of failure. Given that the cumulative distribution of the borrower's failure $F(l, z)=1-\theta(l, z)$ and provided $z>0$, we have that $\partial \theta(l, z) / \partial z<0 \Leftrightarrow \partial F(l$, $z) / \partial z>0$, where $F(l, z)$ is the cumulative distribution function of borrowers' failure.

$L:$ total amount loaned.

$c$ : cost to the lender of issuing a loan.

Without loss of generality, we can assume that the lender expects to operate for an indefinitely long period of time, and we can normalize a lender's expected economic life to 1 . It follows that $n=l^{-1}$. The profit maximization problem for a lender that maximizes her expected profits by choosing the optimal contract tenor can be written as follows:

$$
\max _{l} \pi=l^{-1}\{A[1-F(l, z)]-L(1+c)\}
$$

The first order condition (FOC) of this problem is:

$$
\frac{\partial \pi}{\partial l}=-A+A F(l, z)+L(1+c)-A l \frac{\partial F(l, z)}{\partial l} \equiv 0
$$

as the average recovery rate, pooling both those cases where the full amount is paid with those where (partial) default occurs. 
And the optimal contract maturity derived from the FOC can be written as:

$$
l^{*}=\frac{L(1+c)+A F(l, z)-A}{A \frac{\partial F(l, z)}{\partial l}}
$$

\section{Comparative Statics}

We analyze next the impact of a shock to $z$ on the optimal contract tenor, which is the central issue of interest in this paper. Consider an exogenous shock to $z$ that makes the survival of borrowers up to a future point in time less likely, irrespective of the location of that point in time. The total differentiation of the FOC in (4) yields:

$$
A \frac{\partial F(l, z)}{\partial l} d l+A \frac{\partial F(l, z)}{\partial z} d z-A\left[\frac{\partial F(l, z)}{\partial l}+l \frac{\partial^{2} F(l, z)}{\partial l^{2}}\right] d l-A l \frac{\partial^{2} F(l, z)}{\partial z \partial l} d z \equiv 0
$$

And from (6), the effect of a shock to $z$ on the optimal contract maturity can be written

as:

$$
\frac{d l}{d z}=\frac{\frac{\partial F(l, z)}{\partial z}-l \frac{\partial^{2} F(l, z)}{\partial z \partial l}}{l \frac{\partial^{2} F(l, z)}{\partial l^{2}}}
$$

The intuition that lenders shall choose shorter maturities when there is a negative shock to the economy implies that $d l / d z<0$. From (7) we observe that $d l / d z<0$ holds iff:

$$
\frac{\partial F(l, z) / \partial z}{l \partial^{2} F(l, z) / \partial l^{2}}<\frac{\partial^{2} F(l, z) / \partial z \partial l}{\partial^{2} F(l, z) / \partial l^{2}}
$$

Testing the validity of (8) requires a particular form of $F(l, z)$. I use an exponential distribution to this effect, provided this is arguably the most widely utilized function in survival 
analysis. ${ }^{38}$

Let $F(l, z)$ be an exponential distribution whose probability density function and cumulative distribution function, respectively, are as follows:

$$
\begin{aligned}
& f(l, z)=\left\{\begin{array}{c}
z e^{-z l}, l \geq 0 \\
0, l<0
\end{array}\right\} \\
& F(l, z)=\left\{\begin{array}{c}
1-e^{-z l}, l \geq 0 \\
0, l<0
\end{array}\right\}
\end{aligned}
$$

The second derivative of $F(l, z)$ with respect to $l^{2}$ is negative for all positive values of $z$, and the inequality sign in (8) flips when cancelling this element on both sides, yielding:

$$
\frac{\partial F(l, z)}{\partial z}>l \frac{\partial^{2} F(l, z)}{\partial z \partial l}
$$

Integrating both sides with respect to $d z$ we have:

$$
\begin{aligned}
& \int_{-\infty}^{+\infty} \frac{\partial F(l, z)}{\partial z} d z>l \int_{-\infty}^{+\infty} \frac{\partial^{2} F(l, z)}{\partial z \partial l} d z \\
& F(l, z)>l \frac{\partial F(l, z)}{\partial l}
\end{aligned}
$$

Substituting (9) and (10) for $l \geq 0$ in (13) and operating yields the condition under which

\footnotetext{
${ }^{38}$ Other survival/failure functions could be used alternatively. In particular, the family of Weibull distributions, to which the exponential distribution function belongs, offers suitable alternatives. Specific restrictions on the parameters of the distributions might be required though.
} 
$d l / d z<0$, which is as follows:

$$
\frac{1-e^{-z l}}{z e^{-z l}}>l
$$

It is readily observable that (14) holds for all $l>0$.

\section{Illustration: Aggregate Economic Risk and Optimal Contracts}

Equation (5) provides the solution to the optimal contract tenor for our lender. I give values to the parameters in the model to show how the optimal contract tenor changes with different levels of economic riskiness ceteris paribus. Figure 1 presents the values of $l^{*}$ for different levels of aggregate economic riskiness $z$ assuming the lender uses three alternative setups of transaction margin. The loan amount $L$ is fixed at $\$ 100$, and, under the base transaction margin setup, the repayment amount $A$ is $\$ 105$. The low and high transaction margin setups have repayment amounts of $\$ 104$ and $\$ 106$, respectively. The transaction cost $c$ is 0.02 .

\section{[Insert Figure 1 here.]}

For the base scenario, the optimal contract maturity ranges between 130 periods when the rate of failure is $0.2 \%$ per period and 26 periods when the rate of failure is $1 \%$ per period, showing that the higher the riskiness, the shorter the optimal tenor ceteris paribus. We can also observe in this figure that higher transaction margins offer the lender a more sizeable buffer that allows her lending longer maturities - and in doing so, to take higher credit risk.

The result from (14) predicts that the optimal lender's response to an increase in the level of riskiness in the economy -that is, a positive shock to $z$ such that the probability of a borrower's survival is lower than before the shock- is to shorten the maturity of the new lending contracts. An 
illustration follows.

Figure 2 shows $d l / d z$, or the change in the optimal contract maturity given a shock on $z$. As before, the calibrations correspond to three alternative scenarios of base, low, and high transaction margins where the initial parameter values common to all scenarios are $L=\$ 100, c=0.02$, and $z=0.005$. In the base, low, and high margin scenarios, $A=\$ 105, \$ 104$, and $\$ 106$, respectively. The optimal contract tenors for the base, low, and high margin calibrations solve to $l^{*}=52.10,42.04$, and 60.72 periods, respectively. For the base scenario, an increase of $0.1 \%$ in the failure rate - i.e., $d z=$ 0.001- leads to a shortening of 10.4 periods in the optimal contract maturity. We can also observe that the change in the optimal contract tenor is more sensitive for the high transaction margin setup -which is also the one with longer initial optimal maturity.

\section{[Insert Figure 2 here.]}

\section{ROLLOVER OPTION}

\section{Intuition}

The rollover option is the opportunity a lender has to extend the period she lends her loanable funds by lending again. This rollover option does not necessarily require the loan to be granted to an existing customer or to represent the extension of the maturity of an existing loan. It suffices for the lender to be able to allocate her funds again among the pool of borrowers with funding needs. Notice that this rollover opportunity entails at the same time a screening opportunity. This screening opportunity is expected to be more valuable to the lender under conditions of aggregate economic distress, when credit risks are heightened.

For a lender who expects to do business for a long enough period of time relative to the tenor of her contracts, shortening the maturity of the loans she offers equates to increasing the 
number of rollover options she will enjoy - provided demand for credit exists at the time of rollover. Assuming these options have positive value - which by definition they do - and absent any transactional costs, it would be desirable to have as many options as possible. ${ }^{39}$ Ceteris paribus, an increase in the volatility of the underlying asset will inevitably raise the price of the option, which is evident in the effect of variance on equation (13) in Black and Scholes (1973), making shortening maturities - and thus creating more screening options - a value-creating strategy. For this reason, we should expect to observe shorter maturities in the debt contracts issued during periods of economic distress, when volatility increases.

\section{Isoprices}

We can obtain a prediction similar to that on (14) by analyzing the lending problem from an option pricing perspective. Consider a call option with strike price $\$ 110$, given a market price of $\$ 100$ for the underlying asset - with no dividends or other intermediate payments - and a riskfree interest rate of 5\%. Consider next that shocks to the volatility of the underlying asset are possible, which is true for virtually all assets in our economy, except for those widely considered to be risk-free and intended to be held until maturity.

Furthermore, consider an investor willing to transact bets of particular sizes on the future prices of the assets in the economy. The bets she transacts are options, and the size of each bet is

\footnotetext{
${ }^{39}$ Naturally, there is a limit to the total value added of creating more options, which is a function of the non-zero transactional costs of creating and executing the options. In the case of lending transactions, there are practical limits to the frequency with which both the lender and the borrower would be willing to review and rollover a contract.
} 
the market price of the option she transacts. Holding the strike price constant, given a shock to the volatility, the investor can only make choices on the maturity of the contracts she transacts in order to keep options of her preferred size (price).

Using the Black-Scholes formula for European call options on stocks with no dividends, it is possible to compute isocurves where the price of the option remains unchanged for different combinations of maturity and volatility of the return of the underlying asset, ceteris paribus. Figure 3 presents simulated isoprices under the conditions described above, for call prices of $\$ 10, \$ 20$, and $\$ 30$. An investor with a preference for the isoprice of $\$ 10$, for instance, will choose an option contract with a time to maturity of approximately 1 year when the standard deviation of the rate of return of the underlying asset is $30 \%$, yet she will choose a maturity of only roughly 5 months if the standard deviation rises to $50 \%$.

\section{[Insert Figure 3 here.]}

Now, assume a lender has a preference for the isoprices (value) underlying her rollover options - or her expected return from every lending transaction. Then, given a shock to the volatility of the returns on the underlying asset - the firm value that supports the credit repayment, for instance - the lender will shorten the maturity of new contracts so that to stay on her preferred isoprice.

\section{E. EMPIRICAL EVIDENCE}

In this section, I provide evidence showing that aggregate economic riskiness is strongly associated with shorter debt maturity. In doing so, I use three alternative proxies for riskiness and two distinctly different measures of maturity. The first measure of economic riskiness is the 
Chicago Board Options Exchange (CBOE) Volatility Index (VIX), which measures 30-day expected volatility of the S\&P 500 Index using near-term and next-term call and put SPX options. While an important advantage of this measure is its timeliness, a relative drawback, for the purpose of this study, is the fact that it reflects volatility of the value of equity ownership of the firm, but not directly volatility of the value of assets, which would be a better measure of economic riskiness. For this reason, alternatively, I use the market-based implied volatility of assets of U.S. public firms, derived from the application of the Merton (1974) option pricing formula, and following Bohn and Crosbie (2003), on the data from Compustat Fundamentals Annual and CRSP. This measure is also timely, though, additionally, it reflects the volatility of value of productive assets - as opposed to that of ownership - which adjusts better to the purpose of this study. Lastly, I use the spread between Moody's seasoned Baa corporate bond yield and 10-year Treasury constant maturity yield. This measure is aimed at capturing the investors' consensus on the credit risk of relatively healthy corporations.

The most straightforward and timely measure of debt maturity-revealed preferences comes from new issues of bank and public debt. I use syndicated, bilateral, club, and sole-lender bank loans from DealScan and non-convertible bonds from SDC Platinum. These issues correspond to nonfinancial U.S. firms, were sold in U.S. markets, denominated in U.S. dollars, and had maturities over 12 months at issuance. A second measure of debt maturity comes from debt reported in the balance-sheet by U.S. nonfinancial public firms included in Compustat Fundamentals Annual. Using the temporal structure of debt due at different time intervals, I construct a measure of debt duration that is indicative of the maturity of outstanding corporate debt.

\section{Evidence from New Debt Issuances}


Figures 4 and 5 show how maturity of new debt issues move over time, together with VIX for a reference of aggregate economic distress. In Figure 4, periods of relatively low economic riskiness, such as the first half of 1990s and the period between 2003 and 2006, display increases in the average maturity of new bank debt contracts. In contrast, periods of exacerbated volatility, such as 1998-2002, - with the Russian debt crisis, the Long-Term Capital Management bailout, the bursting of the dot.com bubble, and the events of 9/11 - and the 2007-2009 financial crisis, show significant contractions in the maturity of new bank debt. Figure 5 depicts a very similar picture using the maturity of non-convertible bonds instead.

\section{[Insert Figure 4 here.] \\ [Insert Figure 5 here.]}

The relationships between economic riskiness and maturity of new debt issues is robust. Table 1 reports the correlations between VIX, asset volatility, Baa corporate bond spread over the 10-year risk-free rate, and the maturity of bank debt and public debt for data series between 1990 and 2011. We should first notice that all three measures of economic distress are highly correlated. VIX has a correlation of .56 with asset volatility and .77 with the Baa corporate bond spread. Asset volatility and the Baa corporate bond spread display the lowest value, with .38. All three measures show robust negative correlations with both bank and public debt maturities. The correlation of bank debt maturity with them ranges between -.74 (asset volatility) and -.43 (VIX), while that of public debt maturity ranges between -.73 (asset volatility) and -.31 (Baa corporate bond spread). Furthermore, the correlation between bank and public debt is also high, with .46.

[Insert Table 1 here.] 
Next, I test the relationship between economic riskiness and maturity of new debt contracts in a multivariate framework. Using the model in (15), below, I run OLS regressions using firm, year and industry fixed effects, and cluster standard errors by firm.

$$
\text { Maturity }_{j}=\alpha+\eta L_{j}+\gamma C_{j, t}+\varphi F_{i, t-1}+\gamma R_{t}+\Pi+\Gamma+X+\varepsilon_{j}
$$

Where $\alpha$ is an intercept, $L_{j}$ is an indicator variable that takes a value of 1 if the contract $j$ is a bank loan and 0 if it is a bond issue, $\boldsymbol{C}_{j, t}$, and $\boldsymbol{F}_{i, t-1}$ are vectors of contract and lagged firm characteristics, respectively, $R_{t}$ is a time-dependent vector of interest rates data, $\Pi, \Gamma$, and $\mathrm{X}$ are vectors of firm, year, and industry fixed effects, respectively, and $\boldsymbol{\varepsilon}_{\boldsymbol{j}}$ is the error term. I use a seventeen-industry classification based on Fama and French (1997). Variable definitions can be found in the appendix.

Demand could potentially drive different maturity preferences at times. During periods of relatively high interest rates, borrowers could prefer shorter maturities, expecting to roll over debt in the near future at lower interest rates. Also, with a steep term structure of interest rates, taking the rollover risk of shorter maturities could be preferable to the excessively high cost of debt for long-term debt. For these reasons, I control for the level of risk-free interest rates by including the 1-year Treasury constant maturity rate in the regression models. Additionally, I control for the steepness of the term structure of interest rates with the spread between the 10-year and the 1-year Treasury constant maturity rate.

I use six alternative specifications for robustness. In Table 2, Models 1 through 3 show that the higher the VIX, the asset volatility, or the Baa spread, the shorter the maturity of new debt contracts. These relationships are significant at $5 \%$ level or better and, moreover, the specifications 
can explain between 38 and 39\% of the variation in maturity. Models 4 through 6 control, additionally, for firm credit risk, using the cross-sectional rank of the expected default frequency. As in the first three models, our three proxies for economic riskiness remain statistically significant, and the higher the firm credit risk, the lower the maturity of new debt.

[Insert Table 2 here.]

\section{Evidence from the Existing Debt on the Balance-Sheet of Nonfinancial Public Corporations}

We would expect that shorter tenor in new debt issues result in shorter maturity of the balance-sheet debt of corporations. We should then be able to establish a relationship between the economic conditions and the maturity of corporate liabilities. Figure 6 and Table 3 explore this notion using a graph and correlations. To proxy for corporate debt maturity, I create a measure of debt duration.

The Compustat Fundamentals Annual dataset provides details on the maturity of existing corporate debt. The two main data items are Long-term debt and Debt in current liabilities, which encompasses the current portion of Long-term debt and Notes payable. I add up Long-term debt and Debt in current liabilities to obtain Debt. Long-term debt includes Debt due in Years 2, 3, 4, 5 and beyond. Using this information I create a measure of the following form:

$$
\text { Duration }=1 * \frac{D 1}{D e b t}+2 * \frac{D 2}{D e b t}+3 * \frac{D 3}{D e b t}+4 * \frac{D 4}{D e b t}+5 * \frac{D 5}{D e b t}+6 * \frac{D N}{D e b t}
$$

Where D1, 2, 3, 4, 5 represent the portion of debt that is due in the next $1,2,3,4$, and 5 years, respectively, while DN represents the portion of debt that is due beyond the fifth year.

Figure 6 shows the annual average corporate debt duration in the cross-section of 
nonfinancial firms available in Compustat Fundamentals Annual, together with the annual average month-end VIX. Consistent with the findings on contract data, there is a significant fall in corporate debt duration between 1998 and 2001 and again between 2008 and 2009. The evidence on Table 3 shows, correspondingly, a large and negative relationship between economic riskiness and the maturity of debt in the corporate balance-sheets.

\section{[Insert Figure 6 here.]}

\section{[Insert Table 3 here.]}

I use the level and change of corporate debt duration as alternative dependent variables to run multivariate tests. I run model (17), next, in panel firm-fixed effects regressions, which also include year and industry fixed effects and cluster standard errors by firm.

$$
\text { Duration }_{i, t}=\alpha+c_{i}+\varphi F_{i, t-1}+\gamma R_{t}+\Gamma+X+u_{i, t}
$$

Where $\alpha$ is an intercept, $c_{i}$ is the firm $i$ fixed effect; $F_{i, t-1}$ is a vector of lagged firm characteristics, $R_{t}$ is a time-dependent vector of interest rates, $\Gamma$ and $\mathrm{X}$ are vectors of year and industry fixed effects, respectively, and $u_{i, t}$ is the error term for firm $i$ at time $t$.

Table 4 reports the results of regressing alternative specifications of (17). In Panel A, Models 1 through 3 use duration as the dependent variable, while Models 4 through 6 use the change in duration instead. Consistent with the findings on the contract-level regressions, higher levels of VIX, asset volatility, and Baa spread are associated with decreases in duration of the corporate debt, and these results are significant at the $1 \%$ level in all specifications. As before, the high R-Squared values demonstrate the model's ability to explain variation in duration. 
Specifications in Panel B mirror those in Panel A and include, additionally, year fixed effects. These are the most stringent tests we can run, provided the year fixed effects are likely to absorb part of the aggregate riskiness effect, since the risk variables have only annual values. All results are still robust, with the measures of economic riskiness maintaining the right sign and good levels of significance. Though the Baa spread coefficients do not report stars, they are respectively significant at $13.4 \%$ and $11.9 \%$ in models 9 and 12.

[Insert Table 4 here.]

\section{F. DISCUSSION AND FUTURE DEVELOPMENTS}

Sections II and III develop the intuition of how aggregate economic distress should reduce the maturity of credit. Section IV provides robust evidence suggesting this intuition is observable in new debt issues and its effect extends to firm balance-sheets. Next, I discuss further possible extensions of this work.

The economic model developed in Section II can be extended in at least two meaningful manners. A first extension could accommodate a framework where lender and borrower interact repeatedly while readjusting the terms of new debt until a new equilibrium is reached. The ideal setup for such a model would be a game where agents develop best-response strategies. Assuming incomplete and asymmetric information, a Bayesian approach could be adequate. Specific assumptions regarding the importance of the lender-borrower relationship should be set up in a way that the game can be defined as finite or not, and with known or unknown ending, if finite.

A second extension of interest for the contractual strand of literature relates to the role of covenants at different stages of the economic cycle. Changes in the economic climate can be 
expected to affect the tightness of covenants of new debt. Hence, a model with asymmetric information could develop predictions on the expected changes in covenants and their interaction with maturity.

The fact that the association between aggregate economic riskiness and debt maturity reaches the firm balance-sheets has important economic implications. Shorter effective debt maturity on the corporate financial structure (i) imposes a restriction on the firm's portfolio of investment opportunities - provided that matching the cash flows from assets and liabilities is, at least to some extent, relevant to the firm - and (ii) exposes the firm to higher risks, should it choose to accept the higher likelihood of mismatching cash flows.

Using the establishment of debt recovery tribunals in India, Gopalan et al. (2014) show that better contract enforcement leads to longer debt maturity, which, in turn, results in longer-term firm investment. Gopalan et al. focus on the ratio of fixed assets to total assets as a measure of long-term investment, and this emphasizes the point that longer debt maturity should propitiate investment in infrastructure, a key factor to long-term economic development.

We should also expect longer debt maturity to bolster investment in R\&D, another key element to long-term economic growth and development which is characterized by temporarily distant and uncertain payoffs. All this renders the study of debt maturity and its impact on investment of high practical relevance. Hence, another worthy extension of this paper would include the role of debt maturity on long-term investments in U.S. firms. The significance of debt maturity can be expected to be mitigated by access to multiple funding markets, strong credit reputation, borrowing relationships, existing credit lines, liquidity holdings, and low volatility of cash inflows, among the most relevant aspects. 


\section{G. CONCLUSION}

This paper explores the relationship between aggregate economic distress and the maturity of debt. I have argued that lenders would prefer shorter debt maturity during periods of economic distress, provided heightened borrower default risk and notoriously challenging forecasting conditions. Shorter debt maturities give the lender the opportunity to screen prospective borrowers more frequently, which is a value-creating policy.

I develop two lines of argument based on the debt contracting process to support this prediction. In the first line of argument, a lender chooses the debt contract tenor that maximizes her expected profits. In making this decision, she weighs the role that capital rotation has in her profit function, together with the expected margin on each transaction and the probability that a borrower defaults. The probability of a borrower defaulting is increasing in the level of aggregate economic riskiness. As a result, a shock that reduces economic stability leads the lender to prefer shorter maturities on new debt contracts.

The second argument builds on the concept of the lender's rollover option, which is her opportunity to relend her loanable funds after collection. During times of economic distress this option is more valuable to the lender; hence, she increases her number of options by shortening the maturity of new contracts.

I have empirically tested the relationship between aggregate economic distress and debt maturity on more than twenty years of U.S. bank and public debt issues and have shown this relationship is negative, significant, and robust to different specifications and measures. Moreover, the relationship is strong enough to effectively modify the financial structure of public nonfinancial corporations. 
The implications of these findings are economically important, provided the existing literature has shown that short debt maturity constrains the maturity of assets firms invest in. Firms that can borrow long-term can invest in assets with temporarily more distant cash flows, which makes structural investment more feasible. 


\section{H. REFERENCES}

Acharya, Viral V. and David Skeie. "A Model of Liquidity Hoarding and Term Premia in Inter-Bank Markets.” Federal Reserve Bank of New York, Staff Report No. 498, 2011.

Almeida, Heitor, Murillo Campello, Bruno Laranjeira, and Scott Weisbenner. "Corporate Debt Maturity and the Real Effects of the 2007 Credit Crisis." Critical Finance Review, Vol. 1, 2011.

Ashcraft, Adam, James McAndrews, and David Skeie. "Precautionary Reserves and the Interbank Market.” Journal of Money, Credit and Banking, Vol. 43, No. 7, 2011.

Barraza, J. Santiago E. and Wayne Lee and Timothy Yeager. "Financial Crisis and Supply of Corporate Credit.” SSRN Working Paper, 2422678, 2014.

Black, Fisher and Myron Scholes. "The Pricing of Options and Corporate Liabilities." Journal of Political Economy, Vol. 81, No. 3, 1973.

Bohn, Jeff and Peter Crosbie. "Modeling Default Risk.” KMV White Paper, 2003.

Diamond, Douglas W. "Debt Maturity Structure and Liquidity Risk.” Quarterly Journal of Economics, Vol. 106, No. 3, 1991.

Diamond, Douglas W. and Raghuram G. Rajan. "Liquidity risk, Liquidity Creation, and Financial Fragility: A Theory of Banking.” Journal of Political Economy, Vol. 109, No. 2. 2001a.

Diamond, Douglas W. and Raghuram G. Rajan. "Banks, Short-Term Debt and Financial Crises: Theory, Policy Implications and Applications." Carnegie-Rochester Conference Series on Public Policy, Vol. 54. 2001b.

Fama, Eugene F. and Kenneth R. French. "Industry Costs of Equity." Journal of Financial Economics, Vol. 43, 1997.

Fan, Joseph P. H., Sheridan Titman, and Garry Twite. "An International Comparison of Capital Structure and Debt Maturity Choices." Journal of Financial and Quantitative Analysis, Vol. 47, No. 1, 2012.

Flannery, Mark J. "Asymmetric Information and Risky Debt Maturity Choice.” Journal of Finance, Vol. 41, No. 1, 1986.

Gopalan, Radhakrishnan, Abhiroop Mukherjee, and Manpreet Singh. "Do Debt Contract Enforcement Costs Affect Financing and Asset Structure?” Working Paper, 2014.

He, Zhiguo and Wei Xiong. "Dynamic Debt Runs." Review of Financial Studies, Vol. 25, No. 6, 2012.

Merton, Robert "On the Pricing of Corporate Debt: The Risk Structure of Interest Rates." Journal of Finance, Vol. 29, No. 2, 1974. 
Ozbas, Oguzhan and David S. Scharfstein. "Evidence on the Dark Side of Internal Capital Markets.” Review of Financial Studies, Vol. 23, No. 2, 2010. 


\section{Table 1: Economic Riskiness Maturity of New Debt Issuances - Correlations}

This table presents pairwise correlations between measures of economic riskiness and maturity of new debt contracts between 1990 and 2011. VIX is the annual average of monthly adjusted close values. Firm-level asset volatility is computed as the implied volatility of assets from the application of the Merton (1974) pricing formula for a call option, following Bohn and Crosbie (2003). The asset volatility series used to compute the correlation is the annual average of the monthly cross-sectional averages for all firms in Compustat and CRSP with data available for computation. Baa Corp. Bond Spread is the Moody's seasoned Baa corporate bond yield relative to yield on 10-year Treasury constant maturity. The public and bank debt maturity series represent the annual average of the monthly average for each contract type.

\begin{tabular}{lccccc}
\hline & VIX & $\begin{array}{c}\text { Asset } \\
\text { Volatility }\end{array}$ & $\begin{array}{c}\text { Baa Corp. } \\
\text { Bond } \\
\text { Spread }\end{array}$ & $\begin{array}{c}\text { Bank Debt } \\
\text { Maturity }\end{array}$ & $\begin{array}{c}\text { Public } \\
\text { Debt } \\
\text { Maturity }\end{array}$ \\
VIX & 1.00 & & & & \\
Assets Volatility & 0.56 & 1.00 & & & \\
Baa Corp. Bond Spread & 0.77 & 0.38 & 1.00 & & \\
Bank Debt Maturity & -0.43 & -0.74 & -0.58 & 1.00 & 1.00 \\
Public Debt Maturity & -0.49 & -0.73 & -0.31 & 0.46 & \\
\hline
\end{tabular}




\section{Table 2: Debt Contract Maturity}

The dependent variable is debt contract maturity at issuances, in months. The sample includes bank and public debt issuances between 1990 and 2011. Bank Debt is a limited dependent variable which takes a value of 1 if Bank Debt, and 0, if Public Debt. All borrower controls are lagged one year, with the exception of the EDF Group, which is lagged three months. See appendix for variable definitions. Standard errors are clustered by firm. $* * *, * *, *$ denote significance at $1 \%, 5 \%$, and $10 \%$ levels, respectively.

\begin{tabular}{|c|c|c|c|c|c|c|}
\hline \multirow[b]{2}{*}{ Constant } & \multicolumn{2}{|c|}{ Model 1} & \multicolumn{2}{|c|}{ Model 2} & \multicolumn{2}{|c|}{ Model 3} \\
\hline & 165.00 & $* * *$ & 237.06 & $* * *$ & 212.36 & $* * *$ \\
\hline Bank Debt & -99.45 & $* * *$ & -99.15 & $* * *$ & -99.06 & $* * *$ \\
\hline Amount & -1.15 & $*$ & -1.04 & & -1.04 & \\
\hline Spread & 0.02 & $* * *$ & 0.02 & $* * *$ & 0.03 & $* * *$ \\
\hline \multicolumn{7}{|l|}{ Borrower Controls } \\
\hline Bounded Q & -1.85 & $*$ & -1.80 & $*$ & -1.69 & \\
\hline ROA & 3.40 & & 2.93 & & 2.64 & \\
\hline Assets & 0.07 & & 0.07 & & 0.07 & \\
\hline Fixed Assets/Total Assets & 16.67 & $*$ & 17.69 & $* *$ & 17.65 & $* *$ \\
\hline Cash/Total Assets & 8.43 & & 9.16 & & 9.22 & \\
\hline Financial Debt/Total Assets & -6.87 & $* *$ & -8.02 & $* *$ & -8.31 & $* * *$ \\
\hline Debt Maturity & 3.81 & $* *$ & 4.25 & $* * *$ & 4.35 & $* * *$ \\
\hline \multicolumn{7}{|l|}{ EDF Group } \\
\hline \multicolumn{7}{|l|}{ Economic Conditions } \\
\hline Short-Term Rate & -0.21 & & -1.30 & & -4.54 & $* * *$ \\
\hline Term Structure & -2.77 & $*$ & -4.19 & $* * *$ & -6.37 & $* * *$ \\
\hline VIX & -0.25 & $* *$ & & & & \\
\hline Asset Volatility & & & -1.39 & $* * *$ & & \\
\hline Baa Corp. Bond Spread & & & & & -9.65 & $* * *$ \\
\hline Firm F.E. & Yes & & Yes & & Yes & \\
\hline Industry F.E. & Yes & & Yes & & Yes & \\
\hline Year F.E. & Yes & & Yes & & Yes & \\
\hline Observations & 25,352 & & 25,916 & & 25,916 & \\
\hline Adjusted R-Squared & 0.38 & & 0.39 & & 0.39 & \\
\hline
\end{tabular}


Table 2: Debt Contract Maturity (Cont.)

\begin{tabular}{|c|c|c|c|c|c|c|}
\hline \multirow[b]{2}{*}{ Constant } & \multicolumn{2}{|c|}{ Model 4} & \multicolumn{2}{|c|}{ Model 5} & \multicolumn{2}{|c|}{ Model 6} \\
\hline & 175.45 & $* * *$ & 250.40 & $* * *$ & 215.63 & $* * *$ \\
\hline Bank Debt & -100.49 & $* * *$ & -100.19 & $* * *$ & -100.08 & $* * *$ \\
\hline Amount & -1.37 & $* *$ & -1.22 & $*$ & -1.22 & $*$ \\
\hline Spread & 0.02 & $* * *$ & 0.03 & $* * *$ & 0.03 & $* * *$ \\
\hline \multicolumn{7}{|l|}{ Borrower Controls } \\
\hline Bounded Q & -4.21 & $* * *$ & -4.06 & $* * *$ & -4.00 & $* * *$ \\
\hline ROA & -0.45 & & -0.54 & & -1.41 & \\
\hline Assets & 0.02 & & 0.03 & & 0.03 & \\
\hline Fixed Assets/Total Assets & 16.07 & & 17.44 & $*$ & 17.40 & $*$ \\
\hline Cash/Total Assets & 11.31 & & 10.45 & & 10.36 & \\
\hline Financial Debt/Total Assets & -5.11 & & -6.02 & & -6.34 & \\
\hline Debt Maturity & 3.55 & $* *$ & 3.88 & $* *$ & 3.84 & $* *$ \\
\hline EDF Group & -0.58 & $* * *$ & -0.58 & $* * *$ & -0.61 & $* * *$ \\
\hline \multicolumn{7}{|l|}{ Economic Conditions } \\
\hline Short-Term Rate & -0.56 & & -1.74 & & -4.77 & $* *$ \\
\hline Term Structure & -3.03 & $*$ & -4.47 & $* * *$ & -6.79 & $* * *$ \\
\hline VIX & -0.25 & $* *$ & & & & \\
\hline Asset Volatility & & & -1.58 & $* * *$ & & \\
\hline Baa Corp. Bond Spread & & & & & -9.69 & $* * *$ \\
\hline Firm F.E. & Yes & & Yes & & Yes & \\
\hline Industry F.E. & Yes & & Yes & & Yes & \\
\hline Year F.E. & Yes & & Yes & & Yes & \\
\hline Observations & 19,735 & & 20,041 & & 20,041 & \\
\hline Adjusted R-Squared & 0.38 & & 0.38 & & 0.38 & \\
\hline
\end{tabular}




\section{Table 3: Economic Riskiness and Balance-Sheet Debt Duration - Correlations}

This table presents pairwise correlations between measures of economic riskiness and maturity of new debt contracts between 1990 and 2011. VIX is the annual average of monthly adjusted close values. Firm-level asset volatility is computed as the implied volatility of assets from the application of the Merton (1974) pricing formula for a call option, following Bohn and Crosbie (2003). The asset volatility series used to compute the correlation is the annual average of the monthly cross-sectional averages for all firms in Compustat and CRSP with data available for computation. Baa Corp. Bond Spread is the Moody's seasoned Baa corporate bond yield telative to yield on 10-year Treasury constant maturity. Corp. Debt. Duration is the cross-sectional average duration of balance-sheet debt for non-financial firms in the Compustat Annual data set. Non-financial firms are defined as those with Standard Industry Codes below 6000 or above 6999.

\begin{tabular}{lcccc}
\hline & VIX & $\begin{array}{c}\text { Asset } \\
\text { Volatility }\end{array}$ & $\begin{array}{c}\text { Baa Corp. } \\
\text { Bond Spread }\end{array}$ & $\begin{array}{c}\text { Corp. Debt } \\
\text { Duration }\end{array}$ \\
VIX & 1.00 & & & \\
Assets Volatility & 0.56 & 1.00 & & \\
Baa Corp. Bond Spread & 0.77 & 0.38 & 1.00 & \\
Corp. Debt Duration & -0.52 & -0.82 & -0.61 & 1.00 \\
\hline
\end{tabular}




\section{Table 4: Duration of Debt in the Balance-Sheet}

In models 1 through 3 , the dependent variable is change in the duration of debt in the balance-sheet; in models 4 through 6 , the level of debt duration in the balance-sheet. The sample includes all non-financial firms on Compustat Annual data set between 1988 and 2011. All borrower controls are lagged one year, with the exception of the EDF Group, which is value in December of the previous year, and the change in Financial Debt/Total Assets, which is the difference between the ratio in the current year and the previous year. See appendix for variable definitions. All regressions are panel, fixed effects. The Hausman tests reject the $\mathrm{H} 0$ that random effects estimates are consistent. ***,**,* denote significance at $1 \%, 5 \%$, and $10 \%$ levels, respectively.

\section{Panel A}

Change in Balance-Sheet Debt Duration

\section{Model 1}

Constant

Debt Duration

Bounded Q

ROA

Assets

Fixed Assets/Total Assets

Cash/Total Assets

Financial Debt/Total Assets

$\Delta$ (Financial Debt/Total Assets)

S\&P Rated

EDF Group

\section{Economic Conditions}

Short-Term Rate

Term Structure

VIX

Asset Volatility

Baa Corp. Bond Spread

Firm F.E.

Industry F.E.

Year F.E.

Observations

R-Squared

$\begin{array}{rl}1.80 & * * * \\ -0.52 & * * * \\ 0.05 & * * * \\ 0.03 & \end{array}$

$0.00 * * *$

0.09

0.07

$0.76 * * *$

$1.12 * * *$

$0.16 * * *$

$0.00 * *$

$\begin{array}{rl}-0.02 & * * * \\ -0.02 & * * * \\ -0.01 & * * *\end{array}$

Yes

Yes

Yes

41,757

0.27

41,705
$-0.01 * * *$

Model 2

Model 3

$1.88 * * *$

$-0.52 * * *$

$0.05 * * *$

0.03

$0.00 * * *$

0.10

0.06

$0.77 * * *$

$1.07 * * *$

$0.15 * * *$

0.00

0.00

0.00

$-0.02 * * *$

$0.16 * * *$

$0.00 * *$

0.08

$0.76 * * *$

$1.11 * * *$

$-0.03 * * *$
$-0.02 * * *$

$-0.11 * * *$

Yes

Yes

Yes

Yes

43,286

0.27 
Panel A (Cont.)

\begin{tabular}{|c|c|c|c|c|c|c|}
\hline \multirow[b]{3}{*}{ Constant } & \multicolumn{6}{|c|}{ Balance-Sheet Debt Duration } \\
\hline & \multicolumn{2}{|c|}{ Model 4} & \multicolumn{2}{|c|}{ Model 5} & \multicolumn{2}{|c|}{ Model 6} \\
\hline & 1.83 & $* * *$ & 1.92 & $* * *$ & 2.03 & $* * *$ \\
\hline Debt Duration & 0.45 & $* * *$ & 0.45 & $* * *$ & 0.45 & $* * *$ \\
\hline Bounded Q & 0.05 & $* * *$ & 0.05 & $* * *$ & 0.04 & $* * *$ \\
\hline $\mathrm{ROA}$ & 0.03 & & 0.03 & & 0.03 & \\
\hline Assets & 0.00 & $* * *$ & 0.00 & $* * *$ & 0.00 & $* * *$ \\
\hline Fixed Assets/Total Assets & 0.09 & & 0.10 & $*$ & 0.07 & \\
\hline Cash/Total Assets & 0.07 & & 0.06 & & 0.08 & \\
\hline Financial Debt/Total Assets & 0.76 & $* * *$ & 0.77 & $* * *$ & 0.77 & $* * *$ \\
\hline$\Delta$ (Financial Debt/Total Assets) & 1.12 & $* * *$ & 1.08 & $* * *$ & 1.11 & $* * *$ \\
\hline S\&P Rated & 0.16 & $* * *$ & 0.15 & $* * *$ & 0.16 & $* * *$ \\
\hline EDF Group & 0.00 & $* *$ & 0.00 & & 0.00 & $* *$ \\
\hline \multicolumn{7}{|l|}{ Economic Conditions } \\
\hline Short-Term Rate & -0.02 & $* * *$ & 0.00 & & -0.03 & $* * *$ \\
\hline Term Structure & -0.02 & $* * *$ & 0.00 & & -0.02 & $* * *$ \\
\hline VIX & -0.01 & $* * *$ & & & & \\
\hline Asset Volatility & & & -0.01 & $* * *$ & & \\
\hline Baa Corp. Bond Spread & & & & & -0.11 & $* * *$ \\
\hline Firm F.E. & Yes & & Yes & & Yes & \\
\hline Industry F.E. & Yes & & Yes & & Yes & \\
\hline Year F.E. & Yes & & Yes & & Yes & \\
\hline Observations & 41,762 & & 41,711 & & 43,292 & \\
\hline R-Squared & 0.23 & & 0.23 & & 0.23 & \\
\hline
\end{tabular}


Table 4: Duration of Debt in the Balance-Sheet (Cont.)

Panel B

Change in Balance-Sheet Debt Duration

Model 7

Constant

Debt Duration

Bounded Q

ROA

Assets

Fixed Assets/Total Assets

Cash/Total Assets

Financial Debt/Total Assets

$\Delta$ (Financial Debt/Total Assets)

S\&P Rated

EDF Group

Economic Conditions

Short-Term Rate

Term Structure

VIX

Asset Volatility

Baa Corp. Bond Spread

Firm F.E.

Industry F.E.

Year F.E.

Observations

R-Squared

\section{$1.67 * * *$}

$-0.53 * * *$

$0.05 * * *$

0.03

$0.00 * * *$

0.07

0.04

$0.79 * * *$

$1.13 * * *$

$0.16 * * *$

$0.00 * *$

$$
0.00
$$

$-0.02$

$-0.01$

$* * *$

Yes

Yes

Yes

41,757

0.28
Model 8

$1.99 * * *$

$-0.52 * * *$

$0.05 * * *$

0.03

$0.00 * * *$

0.07

0.05

$0.78 * * *$

$1.10 * * *$

$0.15 * * *$

$0.00 *$

0.01

0.00

$-0.01$

$* * *$

Yes

Yes

Yes

41,705

0.27
Model 9

$1.65 * * *$

$-0.52 * * *$

$0.05 * * *$

0.03

$0.00 * * *$

0.07

0.06

$0.79 * * *$

$1.12 * * *$

$0.15 * * *$

$0.00 * *$

0.01

$-0.02$

$-0.03$

Yes

Yes

Yes

43,286

0.27 


\begin{tabular}{|c|c|c|c|c|c|c|}
\hline \multicolumn{7}{|c|}{ Panel B (Cont.) } \\
\hline & \multicolumn{6}{|c|}{ Balance-Sheet Debt Duration } \\
\hline & \multicolumn{2}{|c|}{ Model 10} & \multicolumn{2}{|c|}{ Model 11} & \multicolumn{2}{|c|}{ Model 12} \\
\hline Constant & 1.70 & $* * *$ & 2.04 & $* * *$ & 1.69 & $* * *$ \\
\hline Debt Duration & 0.45 & $* * *$ & 0.45 & $* * *$ & 0.45 & $* * *$ \\
\hline Bounded Q & 0.05 & $* * *$ & 0.05 & $* * *$ & 0.05 & $* * *$ \\
\hline ROA & 0.03 & & 0.03 & & 0.03 & \\
\hline Assets & 0.00 & $* * *$ & 0.00 & $* * *$ & 0.00 & $* * *$ \\
\hline Fixed Assets/Total Assets & 0.07 & & 0.07 & & 0.07 & \\
\hline Cash/Total Assets & 0.05 & & 0.06 & & 0.06 & \\
\hline Financial Debt/Total Assets & 0.79 & $* * *$ & 0.78 & $* * *$ & 0.79 & $* * *$ \\
\hline$\Delta($ Financial Debt/Total Assets $)$ & 1.13 & $* * *$ & 1.10 & $* * *$ & 1.12 & $* * *$ \\
\hline S\&P Rated & 0.16 & $* * *$ & 0.15 & $* * *$ & 0.16 & $* * *$ \\
\hline EDF Group & 0.00 & $* *$ & 0.00 & $* *$ & 0.00 & $* *$ \\
\hline \multicolumn{7}{|l|}{ Economic Conditions } \\
\hline Short-Term Rate & 0.00 & & 0.01 & & 0.01 & \\
\hline Term Structure & -0.02 & & 0.00 & & -0.02 & \\
\hline VIX & -0.01 & $* * *$ & & & & \\
\hline Asset Volatility & & & -0.01 & $* * *$ & & \\
\hline Baa Corp. Bond Spread & & & & & -0.03 & \\
\hline Firm F.E. & Yes & & Yes & & Yes & \\
\hline Industry F.E. & Yes & & Yes & & Yes & \\
\hline Year F.E. & Yes & & Yes & & Yes & \\
\hline Observations & 41,762 & & 41,711 & & 43,292 & \\
\hline R-Squared & 0.23 & & 0.23 & & 0.24 & \\
\hline
\end{tabular}




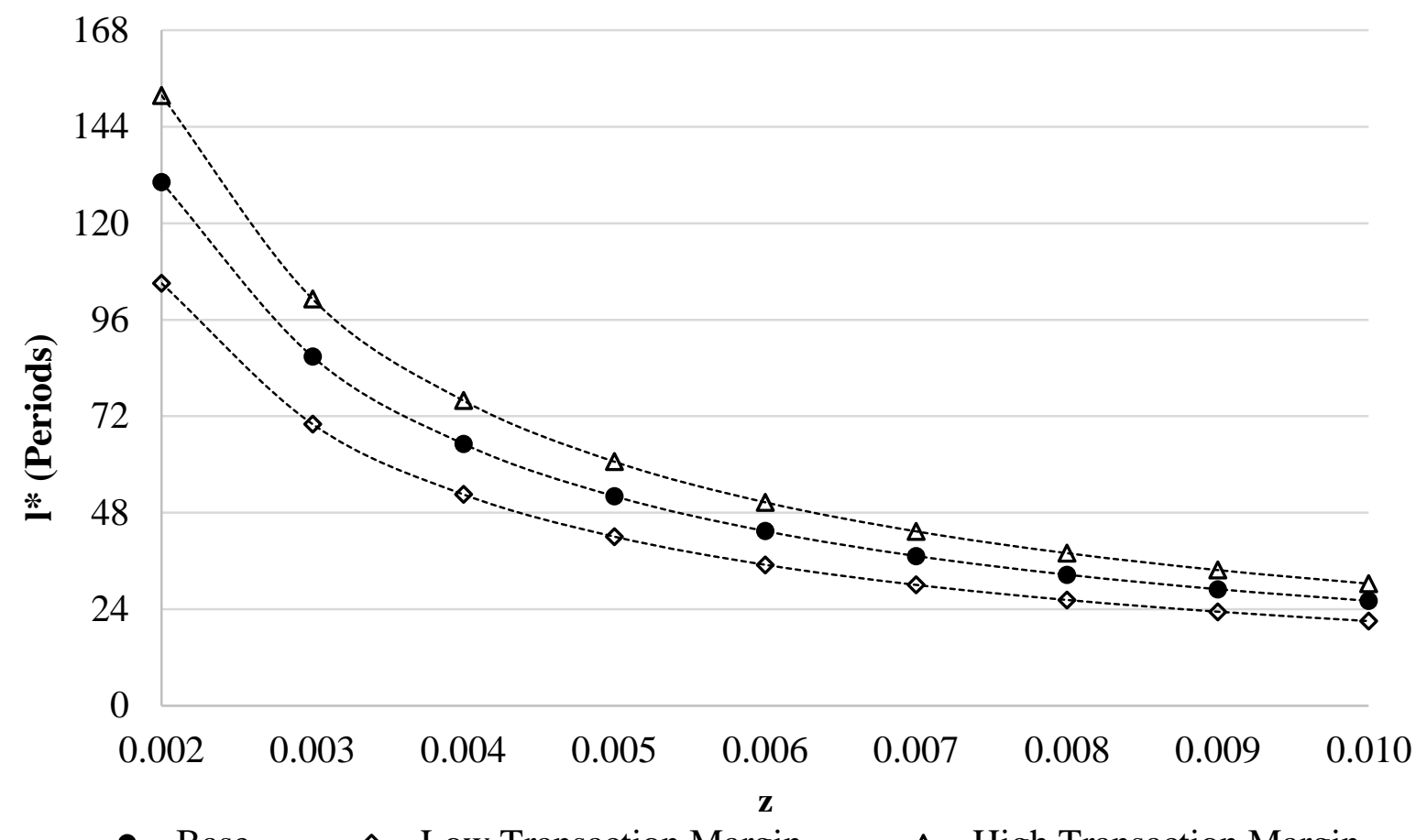

Figure 1. Optimal Contract Tenor $l^{*}$ at Different Levels of Economic Riskiness: Three Scenarios of Transaction Margin. This figure plots the optimal contract tenors $1^{*}$ for different levels of economic riskiness $\mathrm{z}$, under three levels of margin. The initial parameter values common to all scenarios are L: $\$ 100$ and c: 0.02 . In the base, low, and high margin scenarios A: $\$ 105, \$ 104$, and $\$ 106$, respectively. 


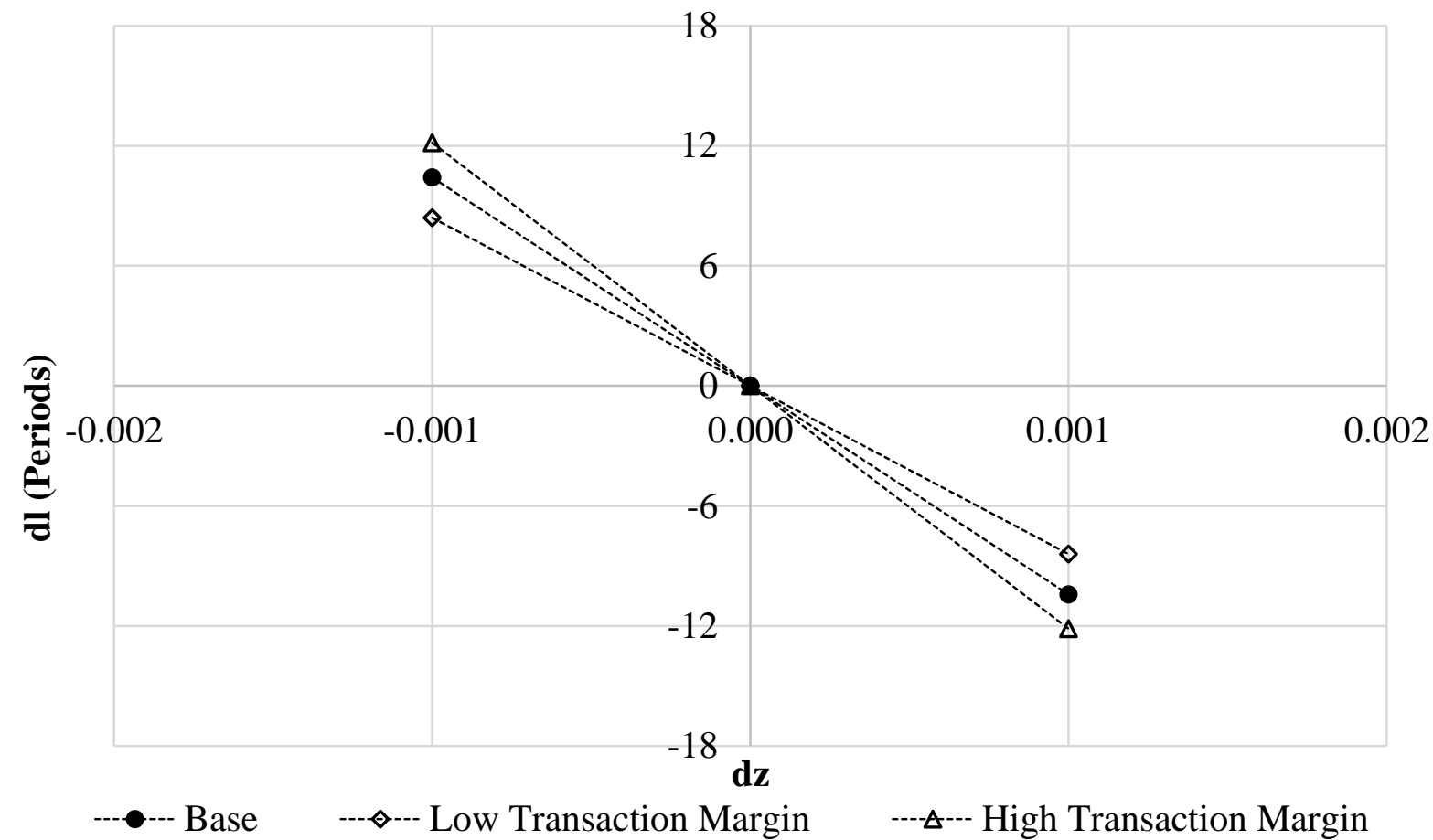

Figure 2. Comparative Statics: Change in Optimal Contract Tenor Given in Shock to Economic Riskiness, dl/dz: Three Scenarios of Transaction Margin. This figure shows the change in optimal contract tenor given an increase (decrease) in the economic riskiness changing $\mathrm{z}$ from 0.005 to $0.006(0.007)$-that is, dz: $0.001(-0.001)-$, for three scenarios with different levels of margin. The initial parameter values common to all scenarios are L: \$100, c: 0.02, z: 0.005 for all scenarios. In the base, low, and high margin scenarios, A: \$105, \$104, and \$106, respectively; and $l^{*}: 52.10,42.04$, and 60.72, respectively. 


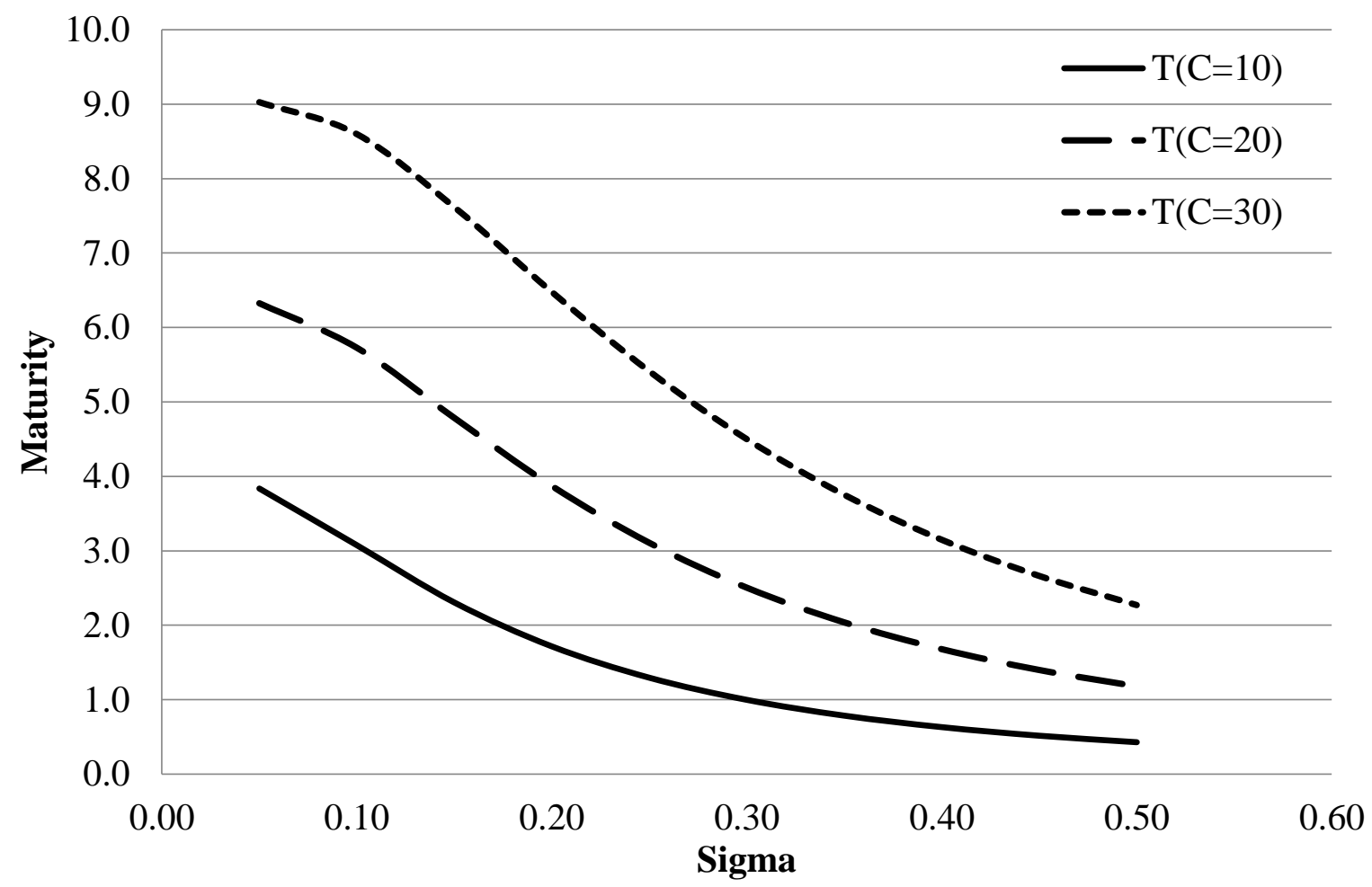

Figure 3. Isoprices of Three Call Options. Isoprices of three call options with strike price 110 $\mathrm{U} \$ \mathrm{D}$, price of the underlying asset $100 \mathrm{U} \$ \mathrm{D}$, risk-free rate $5 \%$ and call prices 10,20 , and $30 \mathrm{U} \$ \mathrm{D}$, computed using Black-Scholes formula for a European call option. Along each isoprice the price of the option is constant for different combinations of Maturity -the time to strike- and Sigma the volatility of the underlying asset-. 


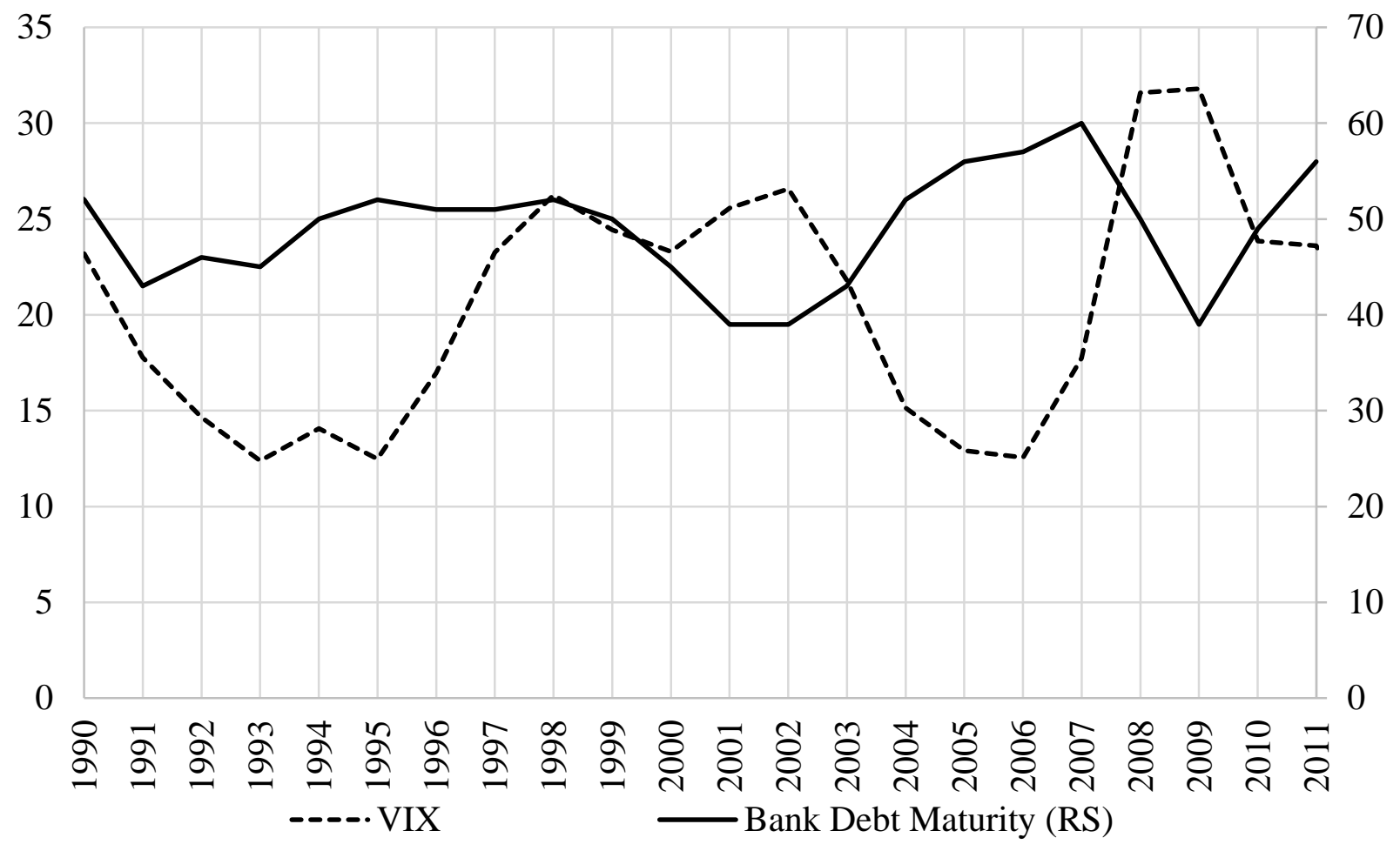

Figure 4. Economic Volatility and the Maturity of New Bank Debt Contracts. This graph plots the annual average maturity of new bank debt contracts from DealScan and the annual average of the month-end VIX values. 


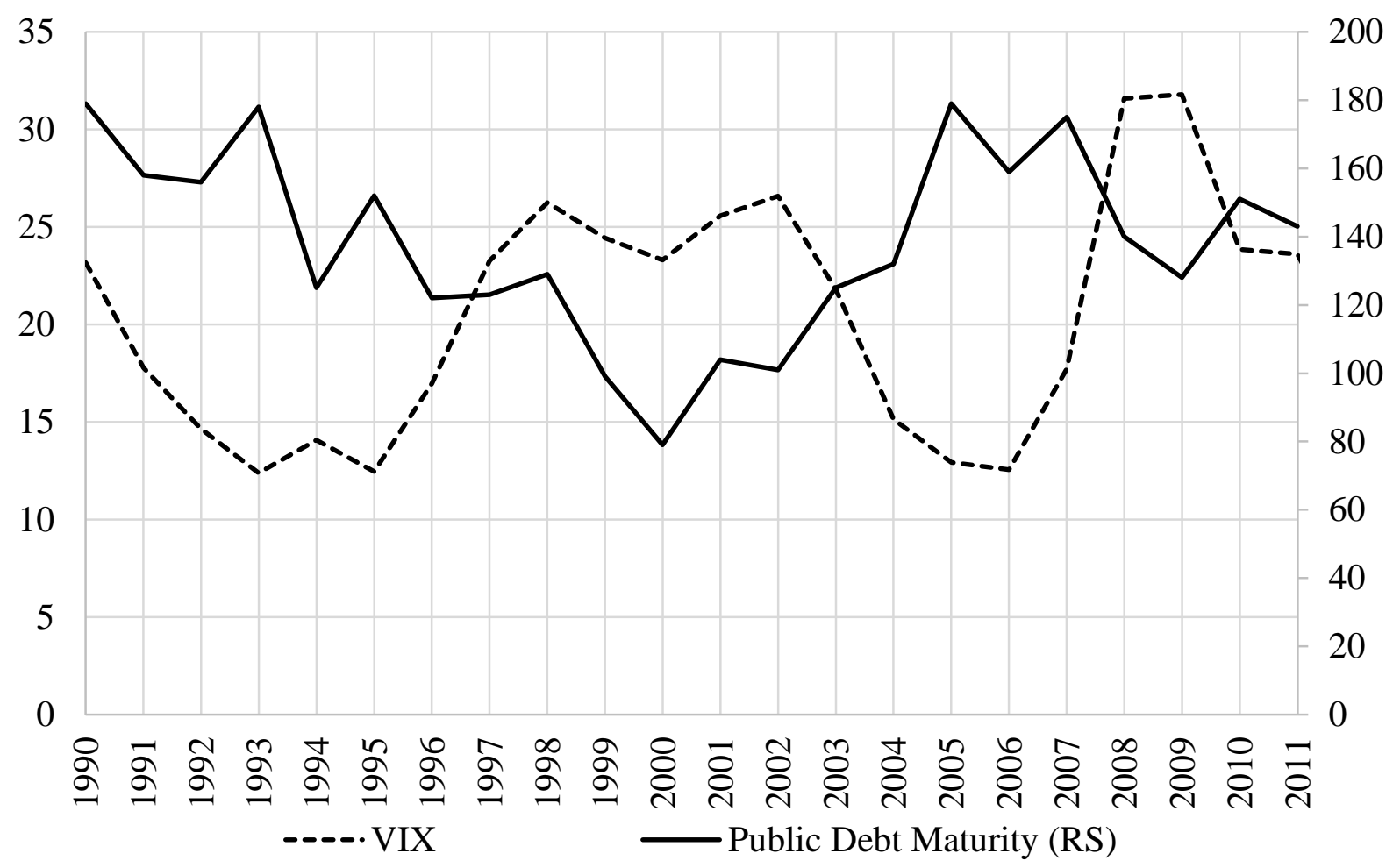

Figure 5. Economic Volatility and the Maturity of New Public Debt Contracts. This graph plots the annual average maturity of new non-convertible bonds from SDC Platinum and the annual average of the month-end VIX values. 


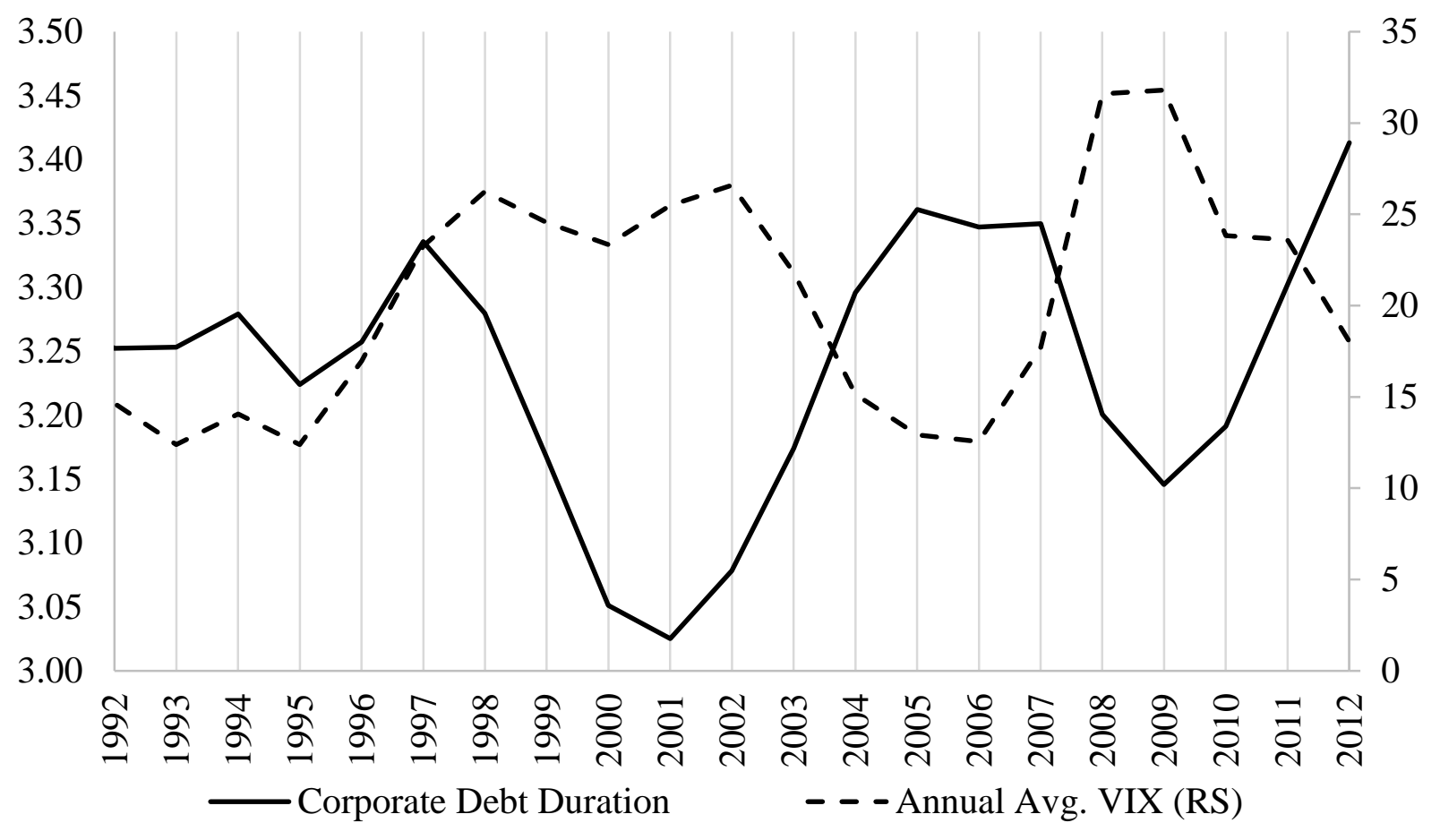

Figure 6. Corporate debt duration and annual average of month-end VIX. Corporate debt duration is the annual average debt duration across all non-financial corporations in the Compustat Annuals database. 


\section{APPENDIX}

Table A.1: Variable Definitions

Variable

Altman's Z-Score

Amount

Asset Volatility

Baa Corp. Bond

Spread

Bank Debt

\section{Definition}

Altman's Z-Score $=1.2($ Working Capital/Total Assets $)+1.4($ Retained

Earnings/Total Assets) +3.3 (Earnings before Interest and Taxes/Total Assets) + 0.6 (Market Value of Equity/Book Value of Liabilities) + 0.999 (Net Sales/Total Assets). Following Altman (1968).

Size of the debt issuance in billions of dollars.

Monthly cross-sectional average implied volatility of assets derived from the application of the Merton (1974) pricing formula for a call option, following Bohn and Crosbie (2003). Computed on all firms on Compustat Fundamentals data base, and with available pricing data on CRSP data base. Expressed in percentage points, unless stated otherwise.

Moody's seasoned Baa corporate bond yield minus yield on 10-year Treasury constant maturity.

Borrowings by non-financial publicly traded firms through syndicated, bilateral, club deal, or sole lender bank loans, with maturity one year or longer, from DealScan. 
Table A.1: Variable Definitions (Cont.)

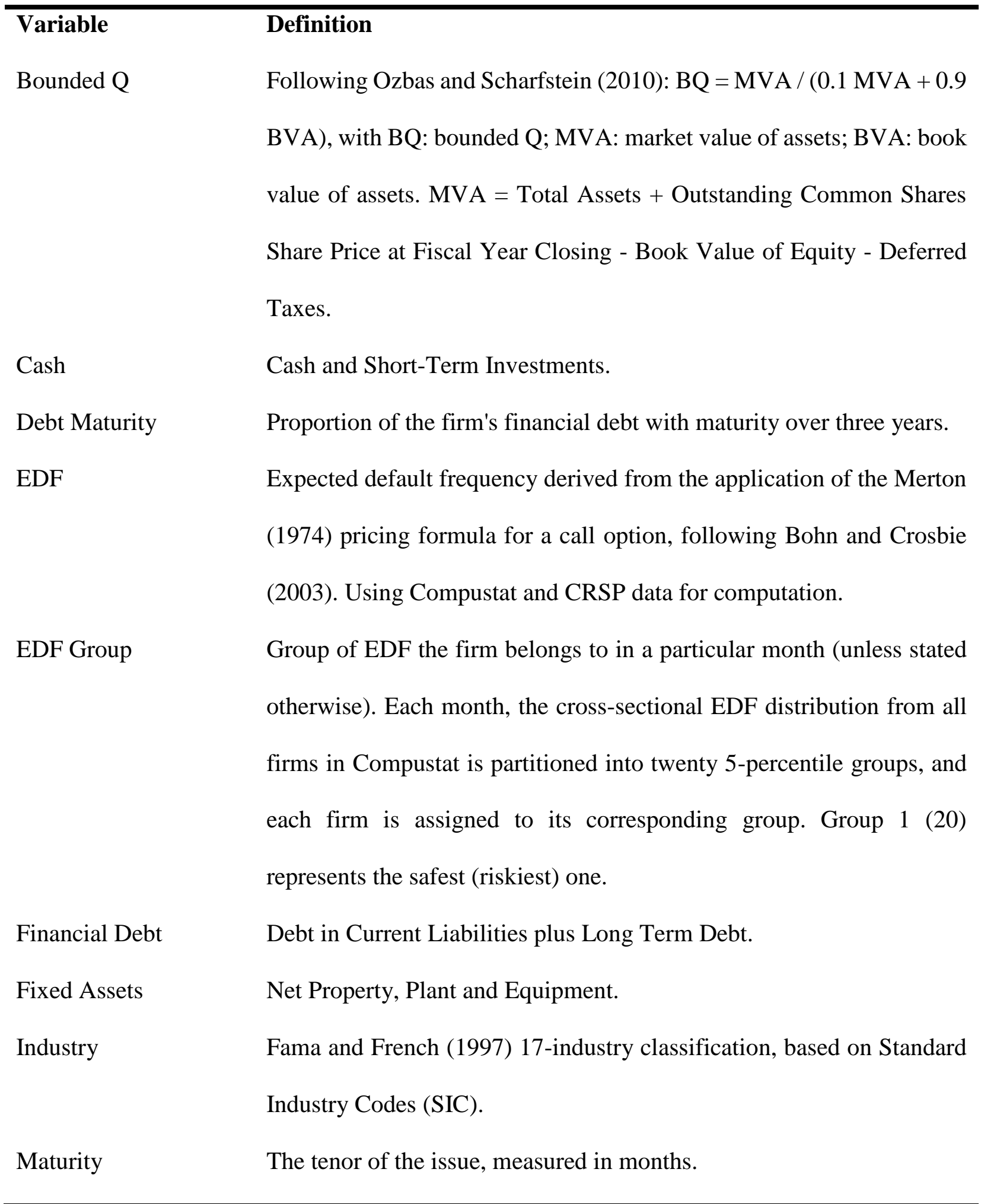


Table A.1: Variable Definitions (Cont.)

\begin{tabular}{ll}
\hline Variable & \multicolumn{1}{l}{ Definition } \\
Public Debt & Borrowings by non-financial publicly traded firms through new non- \\
& convertible debt issues, with maturity one year or longer, from \\
& Thomson Reuters Securities Data Commission (SDC) Platinum. \\
ROA & Ratio of Net Income to Total Assets. \\
S\&P Rating & S\&P domestic long-term issuer credit rating. \\
Short-Term Rate & 1-Year Treasury constant maturity rate. \\
Spread & Difference between the yield on the issuance and the maturity-match \\
yield on a Treasury constant maturity, in basis points. Following \\
Barraza, Lee, Yeager (2014). \\
10-Year Treasury Constant Maturity Rate minus the 1-Year Treasury \\
Constant Maturity Rate, in basis points \\
Expressed in billions of US dollars, unless stated otherwise. \\
Chicago Board Options Exchange (CBOE) Volatility Index. Month-end \\
adructure
\end{tabular}




\section{CONCLUSION}

This dissertation consists of three essays that relate distress and credit. The single most important argument that emerges from it is that heightened risks hinder credit creation, which in time leads to falls in investment and aggregate production. Significant distress in the banking sector leads to bank credit rationing. Certain transparent and reputable firms are able to substitute arms-length credit for bank credit. However, this substitution is incomplete in the aggregate economy, leading to a fall in corporate investment and economic activity. Government intervention can have substantial impact in mitigating the effects of distress in the financial sector, interrupting abrupt falls in loan creation and boosting fast recoveries in the intermediated debt markets.

Aggregate and nonfinancial corporate distress can also affect the market for credits. In particular, this dissertation shows that debt maturity shortens with increases in aggregate and borrower distress. Shorter debt maturities constrain the portfolio of feasible investment opportunities for the firm given the risk that mismatching cash-flows pose, effectively hampering investment in long-term assets -which are essential to long-term growth. 